\title{
CONTEXTOS CERÁMICOS DE LOS SIGLOS V-VII EN CARTAGENA
}

\author{
POR \\ SEBASTIÁN F. RAMALLO ASENSIO \\ Universidad de Murcia \\ ELENA RUIZ VALDERAS \\ Museo Arqueológico Municipal de Cartagena \\ MARÍA DEL CARMEN BERROCAL CAPARRÓS \\ UNED, Cartagena
}

Afri sub Hannibale maritima Hispaniae occupantes, Carthaginem Spartariam construxerunt, quae mox a Romanis capta et colonia facta, nomen etiam provinciae dedit.

Nunc autem a Gothis subversa atque in desolationem redacta est.

(Isid., Etym., XV, I, 67-68)

\section{RESUMEN}

Las excavaciones realizadas en el teatro romano de Cartagena han documentado una amplia secuencia estratigráfica que abarca desde niveles del siglo II a. de C. hasta nuestros días. Especialmente interesantes son los contextos materiales de los siglos $\mathrm{v}$ al viI, asociados a profundas remociones de carácter urbanístico. La construcción en la segunda mitad del siglo $\mathrm{v}$ de un complejo comercial, mercado/almacén, estructurado sobre una gran exedra porticada y una serie de 15 compartimentos alineados, representa la amortización total del edificio del teatro cuyas estructuras en parte fosiliza el nuevo conjunto. Encima de ambas construcciones se construyó un barrio de época bizantina caracterizado por habitaciones de forma cuadrangular que alternan con espacios comunes abiertos y calles de trazado irregular adaptadas a la topografía artificial y en pendiente impuesta por las construcciones precedentes.

\section{SUMMARY}

The excavations realized in the Roman theatre of Cartagena have documented a wide stratigraphic sequence with covers levels from II $^{\text {nd }}$ century B.C. to today. The material contexts of $\mathrm{V}^{\text {th }}$ to $\mathrm{VII}^{\text {th }}$ B.C. are specially interesting because they were associated with considerable removals of the town planning. The construction of a comercial site in the second half of the $\mathrm{V}^{\text {th }}$ century, markets and stores, built on a big exedra with portico and 15 divisions in line, represents the total use of the theatre, the structures of which became fossilized, in part, in a new shape. A village of Byzantin age was built over both constructions, characterized with quadrangular rooms which alternates with opened public spaces and irregular streets adjusted to the artificial and inclined topography dependent on the precedent constructions

\section{CARTHAGO SPARTARIA ENTRE LOS SIGLOS IV-VII}

El expresivo texto de San Isidoro con el que encabezamos este trabajo, parece describir en su pá- rrafo final, una realidad histórica, discutida hasta hace muy poco tiempo y no contrastada arqueológicamente, en torno a la Carthago Spartaria de los siglos $\mathrm{v}$ al viI.

Hasta hace muy pocos años la información relacionada con la ciudad en dicho período se reducía a escasas referencias de carácter literario, en su mayor parte escuetas y a veces oscuras (Hidacio, p. 21, 86,2; Chron. Gall., pp. 664-633), y a unos pocos testimonios arqueológicos. A este respecto, dejando a un lado la famosa y repetida inscripción del Patricio Comenciolo que ha servido durante mucho tiempo como único referente, para atestiguar la presencia e importancia de la ciudad como capital de la ocupación bizantina del mediodía y levante peninsular, el documento arqueológico más importante para época tardorromana ha sido la amplia necrópolis de San Antón, fechada a finales del siglo IV e inicios del v (San Martín y Palol, 1972).

Sin embargo, la revitalización de la actividad arqueológica ha provocado un cambio radical en esta situación que ha coincidido, a su vez, con un creciente interés general por la investigación de este período. El primer jalón en la historia de la investigación reciente sobre la antigüedad tardía en Cartagena se puede establecer con el hallazgo en 1983 de tres paramentos paralelos levantados con opus caementicium y forro de sillares de opus quadratum en el muro exterior que fueron relacionados con restos de la fortificación bizantina descrita en la mencionada lápida de Comenciolo, hallada en 1698 en el patio del Convento de la Merced (Martínez Andreu, 1985). Dejando de momento a un lado el problema de la interpretación de los restos arquitectónicos, la 
recuperación junto a las estructuras de un abundante lote de cerámicas africanas de las formas más tardías (Hayes 104, 105, 107, 109, etc.) sirvió también para revitalizar el análisis de conjuntos cerámicos hallados en otros solares de la ciudad y perfilar su cronología (Méndez, 1985 y 1987). Las excavaciones realizadas en 1983 en la calle Orcel en un solar muy próximo al de la Soledad, pusieron al descubierto la continuación de los paramentos antes descritos con una nueva exedra semicircular y algunas particularidades de carácter técnico que permitieron matizar la cronología y establecer distintas fases en la construcción (Láiz et alii, 1987). Poco después una nueva intervención (1986) en las calles D.Gil/ Orcel permitió constatar un conjunto de habitaciones (tabernae) de cronología tardía superpuestas a un edificio público de época imperial (Láiz y Ruiz, 1988b). En todo este contexto, las excavaciones en la calle del Cañón (1982), Honda 11-13 (1982), y sobre todo la localización de numerosos pozos y basureros de los siglos $\mathrm{v}$ al vir en distintos puntos de la ciudad permitieron una primera relectura de la documentación arqueológica precedente así como plantear nuevas hipótesis sobre su trazado urbanístico en los últimos siglos de la antigüedad (Ruiz et alii, 1993). No obstante, los hallazgos más importantes, tanto por la entidad de los restos como por la amplia seriación de su deposición estratigráfica y por la continuidad y amplitud de los mismos, se han producido en la ladera noroccidental del Cerro de la Concepción, en el espacio comprendido entre la Catedral Vieja y las calles Soledad, Doctor Tapia y Cuesta de la Baronesa, espacio que corresponde prácticamente en su totalidad al solar ocupado por el teatro romano construido en torno al cambio de Era. Estas excavaciones, iniciadas en 1988 y actualmente en curso, han permitido reinterpretar todos los hallazgos anteriores del entorno, además de obtener una visión global del desarrollo urbano de este sector de la ciudad entre los siglos II a.C. y nuestros días (Ramallo et alii, 1993).

Con toda esta información podemos establecer un panorama coherente de la evolución urbana entre los siglos II d.C. y vil d.C. Parece ya fuera de dudas la existencia de un repliegue del espacio urbano ocupado por edificaciones públicas y domésticas desde finales del siglo II d.C. lo que conlleva la amortización de edificios públicos como el de la calle Caballero/San Antonio el Pobre, que muestra un claro nivel de abandono a finales del siglo II (Miquel, 1993), o de las tabernae de la Plaza de San Francisco (Berrocal, 1987), con una amortización de cronología similar. Las modificaciones en el trazado viario se aprecian también durante esta época en el tramo de decumano de la calle Cuatro Santos, $\mathrm{n}^{\circ} 40$ cubierto por capas de relleno y finos lodos durante el siglo III (Miquel, 1987 y Vidal y Miquel, 1988), aunque ello no implique necesariamente su inutilización. A partir de todos estos datos se ha propuesto una reestructuración del espacio urbano que quedaría restringido a la superficie comprendida entre los Cerros del Molinete y de la Concepción. Al mismo tiempo, se propuso también, sobre todo tras los hallazgos de las calles Soledad y Orcel, un proceso de recercamiento de este espacio urbano con la construcción de una nueva muralla que discurriría por las actuales calles de la Aurora y San Antonio el Pobre, trazado que seguirá en gran parte la ciudad amurallada del siglo xvI, encerrando al menos una gran parte de la ladera meridional del Molinete y entroncando con el Cerro de la Concepción. Este lento proceso de transformación de la fisonomía urbana corresponde en parte con la modificación de la situación jurídica de la ciudad que con la reforma administrativa de Diocleciano se convierte en capital de la nueva provincia carthaginiense. Indudablemente este nuevo status debió tener algún reflejo en la arquitectura oficial de la ciudad bien mediante la transformación o reforma de edificios precedentes o bien con la construcción de algún nuevo complejo, dada la situación de abandono que muestran los viejos edificios civiles de los dos primeros siglos. Sin embargo, en este caso, y para este período concreto de fines del siglo III y todo el siglo IV no podemos presentar de momento contextos materiales definidos asociados a estructuras arquitectónicas. La necrópolis de San Antón se tiende ya a fechar, en su momento inicial, en estos años, pero es el único indicio (Láiz y Berrocal, 1995). Sin embargo, la potenciación de este cementerio situado junto a la vía de Complutum y del interior de la Meseta puede constituir un indicio de esa nueva orientación de la ciudad hacia el interior del territorio reforzando así esa situación de capital administrativa y fiscal que en parte subyace bajo la nueva división dioclecianea.

En este contexto de transformaciones urbanísticas se inserta la reconstrucción, más que simple restauración, de las termas públicas de la calle Honda, que se produce en una fecha, que de momento no podemos precisar, entre los siglos IV y v. El edificio, que sigue un sencillo esquema lineal, muestra un estrecho paralelismo con las termas de Baelo, tradicionalmente fechadas en época bajo-imperial, y reutiliza elementos ornamentales de época alto-imperial, como un clípeo circular contorneado por una guirnalda y una posible representación de Medusa en el centro, que apareció desplomado sobre el suelo del frigidarium, 
y un pedestal de mármol veteado de L. Numisio Laeto reempleado como sillar en uno de los muros del caldarium. Sin embargo, esta intensa reutilización de material edilicio se aprecia aún mejor en la construcción de los hipocaustos cuyas pilae se confeccionan con ladrillos circulares recortados, cuadrados, bloques prismáticos de arenisca, y en general material amortizado (Ramallo, 1989-90).

Junto a las termas, la calle que flanquea el edificio por el sur, delimitada a su vez por una serie de anchas y profundas tabernae porticadas de claro carácter comercial, muestra un trazado distinto, oblicuo a la trama casi ortogonal impuesta por la urbanización augustea y parece corresponder en su recorrido a esta nueva reordenación urbanística de época bajo-imperial. Estas remodelaciones se aprecian también sobre un tramo de calzada de cronología posiblemente anterior, tal vez de la trama augustea a juzgar por las características del enlosado que recuerda otros tramos datados en esta fecha como por ejemplo los de la Serreta/San Cristóbal la Corta y Duque 29, que es amortizado con la superposición de muros de características similares a los del complejo comercial del siglo $\mathrm{v}$ levantado sobre el teatro (San Martín, 1973, 47).

Fuera del área pública se observa también una reestructuración de los espacios domésticos con una mayor compartimentación de las viejas viviendas augusteas que, en el espacio reseñado, perviven durante época bajo imperial. Así, en una domus excavada en la C/ Cuatro Santos 17 el peristilo es compartimentado en varias estancias de uso doméstico, mientras que en la vivienda de la c/ Jara 12 se reutilizan y recrecen los muros de fachada orientados hacia un cardo secundario de la fase anterior (Ruiz et alii, 1993).

Sin embargo, el ejemplo más paradigmático y hasta ahora mejor definido de la transformación urbana de la ciudad, nos lo han proporcionado las excavaciones del teatro (fig. 1). En este caso, el viejo edi-

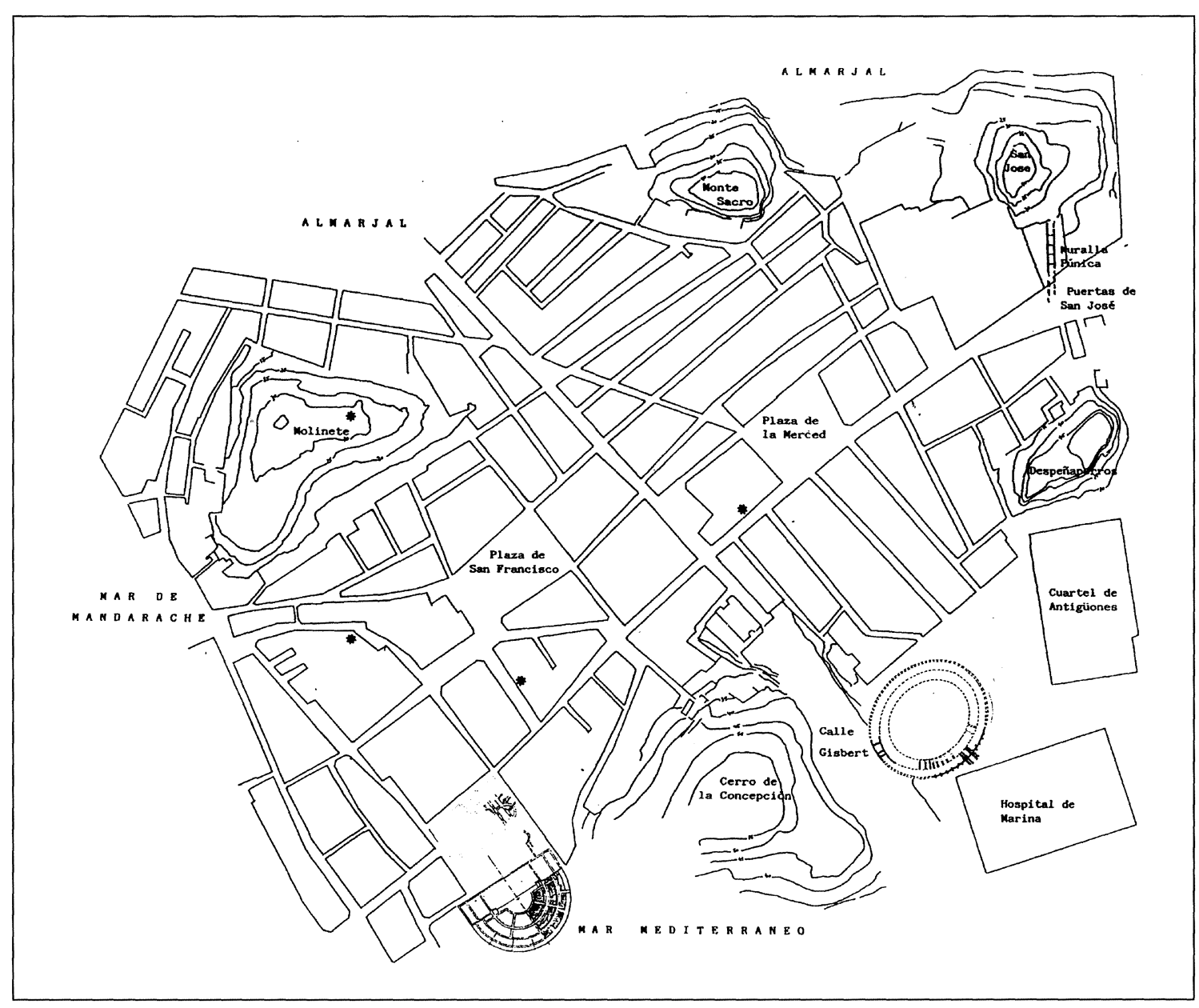

Figura 1.-Plano del casco antiguo de Cartagena, con indicación de pozos y basureros tardíos. 
ficio de espectáculos símbolo de prestigio y uno de los más emblemáticos edificios de la ciudad augustea, parcialmente amortizado, al menos en alguno de sus sectores ya desde finales del siglo II, se transforma por completo durante la segunda mitad del siglo $\mathrm{v}$, con la construcción de un importante complejo comercial, almacén/mercado, que se superpone, reutiliza y en gran parte reaprovecha el material edilicio procedente de la construcción augustea. Capiteles, fustes de columna, basas, cornisas, etc. son incrustados en las cimentaciones del nuevo edificio que se estructura a ambos lados de una calle central que, recrecida sobre las estructuras anteriores, discurre de este a oeste y pone en comunicación los aditi o itinera del teatro, que sobre un nivel superior al del antiguo pavimento de signinum, constituyen los ingresos desde el exterior al nuevo complejo. Hacia el norte, ocupando parcialmente la plataforma cementicia de la escena y el foso del hyposcaenium, salvado con profundas cimentaciones donde se utiliza precisamente gran parte del material arquitectónico del scaenae frons, se articulan alineados 15 compartimentos estrechos y alargados (2,50 de ancho por c. $11 \mathrm{~m}$. de longitud) con ingresos alternativamente hacia el norte y hacia el sur. Al otro lado de la calle, se dispone una exedra semicircular porticada con un rebanco corrido adosado a la pared del fondo y pavimento enlosado que ha fosilizado la estructura original de la orchestra y gradas inferiores de la ima cavea. Tras esta exedra discurre una galería anular cuyo muro de fondo está realizado por piezas de scalae, arrancadas de su posición original de separación de los cunei de la grada, y colocadas de forma contigua una junto a otra. Este complejo edificio es abandonado pocos años después de su construcción, muy probablemente a finales del siglo $\mathrm{v}$ o inicios del siglo vI, y tras un período aún mal definido, donde las evidencias arquitectónicas son muy reducidas, asistimos de nuevo, hacia mediados del siglo vi, a la revitalización edilicia de la zona en forma de un barrio de estructura radial, aterrazado y superpuesto a todas las estructuras anteriores, que en parte condicionan su misma disposición. Fundamentalmente se trata de habitaciones cuadrangulares o trapezoidales unidas en grupos de dos o tres estancias que comunican con espacios abiertos de uso común y entre las que discurren callejones de trazado irregular y adaptado a la topografía escalonada del terreno. La destrucción de la ciudad a manos de los visigodos hacia el 620/625 marca el final de este período y abre una fase oscura en la historia de la ciudad que resurge, al menos en este sector, con edificaciones de carácter doméstico y artesanal entre los siglos XI y XII.

En todo este contexto, y como ya hemos reseña- do más arriba, es difícil precisar el límite amurallado de la ciudad de los siglos IV al viI. Tradicionalmente, y combinando la ausencia de estructuras de habitación en puntos tan significativos como las lujosas viviendas alto imperiales de planta y aparato ornamental típicamente pompeyano de la calle Saura/Beatas y Serreta/San Cristóbal la Corta con los gruesos paramentos de las calles Soledad, Orcel, Cañón, e incluso San Miguel se ha venido señalando una línea de muralla que desde la falda del Cerro de la Concepción podía discurrir por las actuales calle Nueva y Jara hasta el Molinete por el este, y la calle Mayor, interpretada como posible línea de playa, por el oeste. Sin embargo, la reinterpretación de los hallazgos de la Soledad y Orcel a la luz de nuestras nuevas excavaciones en el teatro nos hacen de momento cuestionar esta interpretación hasta que nuevas excavaciones no aclaren diversos puntos controvertidos.

Por otra parte, los niveles asociados a la muralla helenístico-republicana de la Milagrosa no muestran trazas de intervención alguna en épocas tardías e incluso alto imperiales pese a las numerosas inscripciones que recuerdan actuaciones evergéticas sobre torres o distintos tramos del cinturón defensivo en época augustea. Sin embargo, dada la entidad del viejo tramo bárquida-romano que cerraba el único paso de acceso a la ciudad a través del istmo situado entre los cerros de San José y Despeñaperros, hay que considerar el mantenimiento de esta muralla como primer cerco de protección de la ciudad, que a partir de los siglos III y IV encerraría un espacio mucho mayor que el ocupado por los edificios públicos y privados. En este espacio, casi la mitad de la superficie de la vieja ciudad republicana y altoimperial, se detectan numerosos pozos, con gran cantidad de restos óseos asociados a materiales cerámicos de finales del siglo vi y principios del viI, excavados en los niveles de disolución de adobes de las viviendas de los siglos I y II (Duque 33, Jara, 12, 21-23 y Cuatro Santos 17) y vertederos de mayores dimensiones y más dilatado uso como los de la c/ Palas 8 y Caballero 2-8, con cerámicas características de los siglos v al vir. De momento desconocemos si este amplio sector de la vieja ciudad altoimperial fue abandonado por completo o si bien, como se ha propuesto en otras ciudades, pudo haber sido utilizado como una superficie intramuros ocupada por pequeños espacios dedicados al cultivo, trasladando al interior del recinto amurallado parte de las áreas cultivadas situadas hasta entonces en los alrededores (Gutiérrez, 1993, con la bibliografía al respecto).

Los datos aportados reflejan una vitalidad urba- 


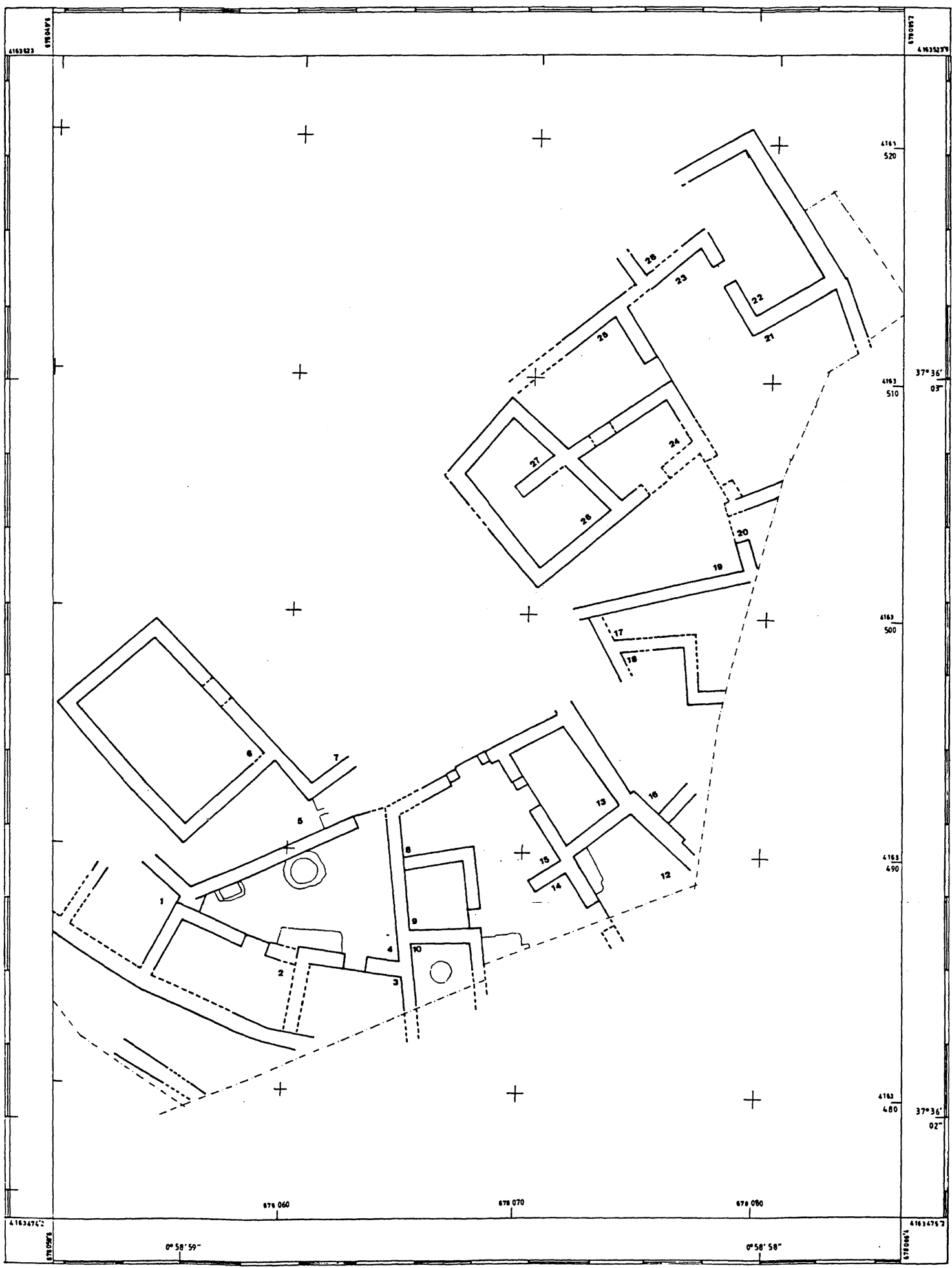

Figura 2.-Barrio de época bizantina instalado sobre el teatro romano. 
na que encuentra además plena confirmación en la cantidad, calidad y variedad de las producciones cerámicas, locales o importadas, halladas en el solar urbano. Una muestra reducida de este amplio volumen estudiamos en los párrafos que siguen.

\section{DESCRIPCIÓN DE LOS CONTEXTOS ANALIZADOS}

Como ya hemos señalado más arriba los contextos cerámicos analizados en el presente artículo proceden de la campaña realizada en 1994 en el teatro romano de Cartagena y corresponden a las habitaciones 2, 3, 4 y 5 del denominado barrio de época bizantina y de los niveles subyacentes y de abandono y construcción del mercado/complejo comercial, situado sobre el edificio augusteo y junto a las instalaciones portuarias (fig. 2).

Del conjunto de 19 fases documentadas en nuestras excavaciones, que abarcan entre el siglo II a.C. y nuestros días, se estudian aquí las definidas como 8.2 relleno de nivelación que amortiza y oculta por completo las estructuras del teatro, 8.1 nivel de abandono del complejo comercial, 9.2 relleno de colmatación sobre el que se levantan las habitaciones de la primera mitad del siglo vI, 9.1 nivel de abandono y amortización de estas estructuras, 10.5 relleno de nivelación que precede a la construcción de la fase inicial del barrio de época bizantina, 10.4 suelos y preparados de esta fase anterior, 10.3 suelos y preparados de la segunda fase del barrio de época bizantina, 10.2 que corresponde al nivel de destrucción del barrio de época bizantina, del cual analizamos aquí el material de tres habitaciones, y por último la fase 10.1, que define el abandono de todo este sector, tras su destrucción violenta.

Se trata de una muestra suficientemente significativa que se puede hacer extensiva al resto de la excavación según hemos podido comprobar en la campaña más amplia de $1995^{1}$.

\section{Fase 8.2 Nivel constructivo del mercado}

La fase 8.2 corresponde a los estratos de nivelación utilizados en la construcción del edificio comercial. Estos niveles han sido identificados en los itinera, bajo los suelos de las tabernae, en la plaza circular de la exedra y en la galería superior que

1 Agradecemos a los Dres. Javier Aquilué y Luis Caballero la lectura crítica del manuscrito y las interesantes sugerencias y observaciones que nos han formulado y que han contribuido a mejorar la calidad de este trabajo. rodea la exedra. El estrato se caracteriza por una tierra de color amarillento procedente de la arenisca triturada y compactada con piedras menudas, contiene escaso y fragmentado material cerámico, pero su contexto es altamente significativo para la dotación del edificio comercial. El material que analizamos en este trabajo procede de los rellenos de nivelación realizados sobre las gradas superiores de la ima cavea para la construcción de la galería superior.

El contexto cerámico viene determinado por la presencia de T. S. Africana Clara D, especialmente la producción D2, en sus formas Hayes $61\left(\mathrm{n}^{\circ} 1\right), 63$ $\left(n^{\circ} 3\right), 91 \mathrm{~A}\left(\mathrm{n}^{\circ} 2\right)$ y un fondo con decoración del estilo A (ii) ( $\left.n^{\circ} 4\right)$. La forma Hayes 61 es uno de los platos más abundantes en la vajilla de mesa entre los años 325 y 450 (para su difusión, vid. Carandini et alii, 1981, 83). Aparece en Ostia en contextos de fines del siglo Iv e inicios del siglo v, y en Carthago en los siglos IV y v. Es también muy abundante en todo el levante peninsular y se registra, entre otros yacimientos, en Rosas (Nolla, 1984, 444; Nieto, 1993), Badalona (Aquilué, 1987, 165), Tarragona (Aquilué, 1989, 125-129), Mallorca (Orfila, 1988, 513), Pollentia (Martín, 1983, 191) y Valencia (Reynolds, 1984, 512). Para la forma 63, Hayes (1972, 109) propone una datación entre el 375 y el 400 , aunque está atestiguada en Carthago en estratos fechados entre el 360 y el 440 .

Una asociación de formas similar a la de nuestro relleno se manifiesta en el cargamento del pecio de Port Miou, donde se documenta la exportación conjunta de H. 61, 63, 91 junto a otras formas H. 67 y $80 \mathrm{~B}$, y fondos con decoración A (ii) similares a nuestro ejemplar $n^{\circ} 4$. El hundimiento del pecio, inicialmente situado en el último cuarto del siglo IV (Deneauve, 1972, 223) ha sido reconducido al primer cuarto del siglo v o quizás a mediados del mismo (Hayes, 1980, 482), datación que sirve para precisar la cronología inical del cuenco Hayes 91 situada, en un primer momento, hacia la segunda mitad del siglo $v$ (Hayes, 1972, 144) y posteriormente reconducida a finales del siglo Iv (Hayes, 1976, 86; 1980, 516; Tortorella, 1981, 366) a partir, sobre todo, de las estratigrafías de Carthago (Atlante I, 1981, 106).

También de origen africano encontramos en este estrato un fragmento de plato tapadera de borde negrito $\left(n^{\circ} 6\right)$ y un fragmento de olla de pátina cenicienta ( $n^{\circ}$ 9) tipo Vila-roma 5.40. Este grupo de ollas con concavidad interior, asas y cuerpo globular cuyos diámetros oscilan entre 13 y $16 \mathrm{~cm}$., es el más numeroso en el abocador de Vila-roma fechado entre el 400-450 (Aquilué, 1989b, 196); también 
está presente en Carthago en el depósito A1. 022 datado a principios del siglo $v$ (Hayes, 1976, 70), y son similares a la forma 19 de Fulford y Peacock $(1984,184)$, datada a finales del siglo IV e inicios del siglo v (Aquilué, 1989b, 196 ss.).

En cuanto a la cerámica común destacan dos fragmentos de mortero de producción indeterminada, aunque el $\mathrm{n}^{\circ} 8$ pudiera ser de fabricación africana, y de tamaño medio cuyos diámetros oscilan entre 13 y $20 \mathrm{~cm}$. $\left(\mathrm{n}^{\circ} 7\right.$ y 8$)$. El ejemplar $\mathrm{n}^{\circ} 7$ se puede relacionar con la forma W1,19 J-3 de Reynolds (1993, 106, lám. 13) aunque presenta un diámetro menor $(130 \mathrm{~mm}$.). También es de cerámica común una jarra de producción ibicenca $\left(\mathrm{n}^{\circ} 5\right)$ similar a la forma RE 0204 b (Ramón, 1986, 17), de cuello estrecho y alargado, asas verticales y cuerpo ovoide fechados por el autor entre 550-570 aunque los ejemplares que ilustran la forma pertenecen a yacimientos con una cronología más amplia. En concreto el ejemplar de Can Frit apareció fuera de contexto y el de Can Gavin pertenece a la tumba 3 fechada en el siglo VI, aunque la necrópolis data de los siglos III-VII. Nuestro ejemplar debe ser fechado por el resto del contexto en la primera mitad del siglo $\mathrm{v}$ d.C.

En este estrato también se han localizado, aunque de manera muy escasa, fragmentos de cerámica de cocina tosca local $\left(\mathrm{n}^{\circ} 10\right)$, precedentes de la que luego se desarrollará sobre todo a partir del siglo vi. Corresponden a una olla de la forma 2 , de borde vuelto, cuello marcado y cuerpo globular, de características similares, técnicas y formales, a las de la C/ Era del Puerto de Mazarrón, fechadas en contextos de la primera mitad del siglo v d.C. (Ruiz Valderas, 1991, 48).

En cuanto al material anfórico están presentes en este estrato ánforas de producción africana, probablemente tunecina, Keay XXXVIB ( $\left.\mathrm{n}^{\circ} 11\right)$, destinadas al transporte de aceite de oliva. Este envase, caracterizado por su cuerpo cilíndrico, hombro redondeado, cuello corto y cónico, borde engrosado al exterior y asas que arrancan casi del borde, se constata en el vertedero de Vila-roma en el segundo cuarto del siglo v (Remolá y Abelló, 1989, 263), así como en la Bourse de Marsella (Bonifay, 1986, 276), con una cronología similar, fecha considerada como la de su introducción en los mercados del Mediterráneo Occidental. En el claustro de la Catedral de Tarragona se documenta a mediados del siglo $\mathrm{v}$, mientras que en Rosas su presencia se localiza desde finales del siglo $\mathrm{v}$ hasta principios del siglo vI (Martín et alii, 1979, 66 ss.). En Carthago no se documenta esta forma antes del período 450-475 (Fulford y Peacock, 1984, 131, fig. 40), al igual que sucede en la Schola Praeconum donde no se registra antes del 430-440 (Whitehouse et alii, 1982, 76, fig 10). En Cartagena, dado el contexto en que se inserta tendemos a situar esta forma en el segundo cuarto del siglo $\mathrm{v}$ d.C., datación que coincide con las de Tarraco y Marsella.

En esta misma fase conviven con las producciones africanas, ánforas de origen oriental representadas en la forma Keay LIII/LRA 1 ( $\left.n^{\circ} 12\right)$ cuya fecha inicial se registra ya en el segundo cuarto del siglo v d.C. dada su presencia en el vertedero de Vila-roma. Se trata de un ánfora de cuerpo ovoide, con dos asas situadas de labio a hombro y fondo no diferenciado, cuello recto, de borde ligeramente engrosado, más o menos exvasado según la forma. Respecto al centro de fabricación, Willians (1982, 102-103), basándose en los análisis mineralógicos, propuso el área del norte de Siria, probablemente la región de Antioquía (Peacock y Willians, 1986, 187), desde donde se pudo exportar aceite en estos contenedores (Keay, 1984, 271). En los mercados del Mediterráneo occidental su presencia aumenta desde mediados del siglo $\mathrm{v}$ y a lo largo del siglo vI, como se atestigua en Carthago (Hayes, 1985, 40; Fulford y Peacock, 1984), Tarragona (Dupré y Carreté, 1993, 153), Mataró, villa de Torre Llauder, en un vertedero de la segunda mitad del siglo v y principios del vi (Clariana y Járrega, 1994, 264) y en diversos vertederos de Cartagena (Láiz y Berrocal, 1991, 321-340; Roldán et alii, 1991, 305-319), siendo los hallazgos más tardíos los de principios del siglo vil de Yassi Ada (Bass y van Doorninck, 1982), Saraçhane, de entre el 650-670 (Hayes, 1968, 215) y Tocra, con ejemplares de mediados del siglo vil (Boardman y Hayes, 1973, 116-117). En Classe, donde se encuadra dentro del Grupo 3 (ánforas 8.10-8.13) se halla en los niveles altos, datados en el siglo vi avanzado (Stoppioni, 1983, 132).

Entre las importaciones orientales hay que incluir también la forma Keay LIV/LRA 4 ( $\left.\mathrm{n}^{\circ} 13\right)$ que hace su aparición en Marsella a mediados del siglo IV (Bonifay, 1986, 281) y en Carthago a finales del mismo siglo (Hayes, 1976, 50). Es un ánfora ovoide, de cuello muy corto con dos pequeñas asas anulares en la parte superior y fondo troncocónico; suele llevar, a modo de decoración, una banda de incisiones a la altura de la parte inferior del asa y generalmente cuenta con unas aplicaciones de arcilla en el borde muy características. Se suele considerar Gaza como centro de producción de este tipo anfórico (Whitehouse et alii, 1985, 200-203). Su presencia en los mercados mediterráneos se incrementa en la primera mitad del siglo $\mathrm{v}$, como se refleja en el vertedero de Vila-roma (Remolá y Abe- 
lló, 1989, 284-285), en la Schola Praeconum de Roma (Whitehouse et alii, 1982, 69) y en Carthago (Neuru, 1980, 204). Son así mismo muy abundantes los hallazgos fechados en el siglo vi o inicios del vII, como los de La Bourse (Bonifay, 1986, 292), Schola Praeconum (Whitehouse et alii, 1985, 181) y Ramath Rahel (Aharoni, 1964, lám. 24.9) entre otros ejemplos.

De momento, y hasta que no ampliemos el estudio a toda el área de excavación, la presencia de dos ejemplares orientales frente a una sola ánfora africana en esta fase, no tiene por qué ser muy indicativo de los porcentajes cuantitativos de ambas producciones. No obstante, es conveniente reseñar cómo en contextos de la primera mitad del siglo $\mathrm{v}$, tales como en La Bourse de Marsella, hay mayoría de ánforas orientales frente a las africanas, mientras que en Vila-roma y Schola Praeconum los porcentajes se equiparan con una ligera mayoría en Roma para las ánforas africanas, al tiempo que en Carthago, proporcionalmente se documentan el doble de ánforas africanas que orientales.

\section{Fase 8.1 Nivel de abandono del mercado}

La fase 8.1 agrupa los estratos de abandono y colmatación del edificio comercial. Estos estratos se caracterizan por una tierra marrón clara, suelta, con abundantes escombros, derrumbes, restos de argamasa y gravilla. La colmatación del complejo comercial se produce tras el expolio de materiales constructivos, de forma que las losas que pavimentan la exedra y las tabernae aparecen en muchos casos substraídas.

El material cerámico de las UEs. 4379 y 4380 corresponde concretamente a los estratos de abandono depositados sobre la exedra porticada del edificio comercial. En estos niveles aparecen representadas cerámicas en T. S. Africana Clara D formas Hayes 80B $\left(\mathrm{n}^{\circ} 18\right), 89\left(\mathrm{n}^{\circ} 20\right), 93 \mathrm{~A}\left(\mathrm{n}^{\circ} 21\right), 99$ A-B $\left(n^{\circ} 15-17\right)$ y $104 A\left(n^{\circ} 19\right)$. La forma Hayes $80 B$ aparece en Carthago en estratos de la primera mitad del siglo $\mathrm{v}$ anteriores a la ocupación vándala y en estas mismas fechas se documenta también en el templo de la Magna Mater de Roma (Carignani, 1986). Hayes sugiere una cronología entre el 450 500. Las formas 89 y $93 \mathrm{~A}$ son características de la segunda mitad del siglo $\mathrm{v}$, que continúan claramente durante la primera mitad del siglo vi (Hayes 1980, 517). Para la segunda, Hayes propuso una datación entre el 470-500, aunque posteriormente consideró que su cronología inicial podía remontarse a la primera mitad del siglo v. En el extremo opuesto, se documenta en Carthago en contextos datados entre el 500-560.

Mas problemático es aquilatar la cronología de la forma Hayes 104A. Para determinar el inicio de la producción, es significativa su presencia entre los materiales de la segunda fase del taller de El Mahrine, datada entre el 460-480 y asociada a las formas Ostia III, fig. 128 y Atlante XLVI, 9-10 (Mackensen, 1985, 32). Sin embargo, es sobre todo frecuente en contextos de la primera mitad del siglo VI como los del oppidum de Sainte Popice (Boixadera et alii, 1987, 98) o en el depósito vil de las excavaciones americanas en Carthago (Michigan, I). En Tarragona, la forma 104A, documentada al menos por tres ejemplares en la sede del Colegio de Arquitectos, aparece generalmente representada en estratos del siglo vi (Aquilué, 1993, 108). Respecto a la cronología inicial de la forma 99 A-B fechada en un primer momento por Hayes a partir del 530 , y documentada también en Carthago en niveles fechados entre el 523-533 (Fulford, 1984, 73-74) fue revisada por su presencia en Conimbriga en los estratos de destrucción datados entre 465-468 (Delgado, $1975,270)$. Por otra parte, la asociación de las formas Hayes 99 y $104 \mathrm{~A}$ en un mismo contexto se halla en la Bourse de Marsella, Período 2A, fase 3, fechada a finales del siglo $\mathrm{v}$ o inicios del vI (Bonifay, 1983, 314). La forma Hayes 99 (A y B) es la más numerosa en el nivel de abandono de una domus sobre el Celio, junto a los tipos de africana Hayes 93, 104A y las ánforas Keay XXVI (con distintas variantes), XXXVIB, LVB y LXII. La formación de este depósito se tiende a situar entre el 480 y el 550, mientras que el cierre definitivo se habría producido entre finales del siglo vI e inicios del vII (Pacetti y Sfrecola, 1989, 486).

En cerámica de cocina africana destaca un mortero ( $\left.n^{\circ} 23\right)$ vinculado al grupo 2 de Fulford (1984, Fig. 76. 2), con una cronología inicial centrada a principios del siglo vi.

En cuanto a la cerámica común aparecen representados cuencos ( $\left.n^{\circ} 24-26\right)$, que morfológicamente derivan de los tipos altoimperiales de borde entrante Vegas 21.4 y 21.5 (Vegas, 1973, 21, fig. 20), platos de fondo plano con reborde $\left(\mathrm{n}^{\circ} 29\right.$ y 30$)$, forma no muy abundante en contextos de la primera mitad del siglo v (TED'a, 1989, 224-225) y una jarra de sencillo perfil exvasado y borde no diferenciado $\left(n^{\circ} 27\right)$, de pastas amarillentas, emparentada con la forma Vegas 40 (Vegas, 1973, 97, fig. 23) y con la forma Ostia I, fig. 38, que presenta paralelos en el Valle del Vinalopó datados ampliamente entre el siglo IV y vil d.C. (Reynolds, 1993, 102, lám. 6). Otra de las jarras documentadas $\left(\mathrm{n}^{\circ} 28\right)$, de arcilla ma- 
rrón, podría ser una importación posiblemente oriental. También de producción africana, se documenta un mortero con visera y ondulaciones en el borde $\left(n^{\circ} 32\right)$, similar a los registrados en Benalúa entre finales del siglo $\mathrm{v}$ y mediados del siglo viI así como dos cuencos/mortero ( $\left.n^{\circ} 33-34\right)$, con visera y de pequeñas dimensiones, de producción indeterminada, que se pueden relacionar con la forma W1, 19, J-3 de Reynolds (1993, 106, lám. 13). El primero de ellos tiene la visera pequeña y elevada con marcadas líneas de torno en el exterior, mientras que el segundo presenta una larga visera inclinada decorada por un reticulado impreso con restos de un engobe de color rojizo. Respecto a los cuencos existen modelos similares en Ibiza, tipos RE-0802a y RE-0803a datados entre 250 y 700 (Ramón, 1986, fig.11).

En estos estratos comienzan a aparecer, aunque todavía en un porcentaje bajo, las cerámicas de cocina de producción local, que se caracterizan por un mejor acabado y factura que las posteriores. En líneas generales, se trata de cerámicas fabricadas con unas arcillas rojizas o anaranjadas, poco depuradas, granulosas, con abundantes desgrasantes de tamaño medio y grueso de esquistos grises, azulados y violáceos así como finos de mica. Las superficies exteriores son rugosas al tacto, de factura grosera y pueden estar simplemente alisadas, con o sin engobe. Dicha superficie exterior y el borde aparecen ennegrecidos debido a su exposición al fuego. La mayoría de estos recipientes están realizados a torno, aunque los ejemplares mas tardíos pueden estar modelados a mano o a torno lento (Láiz y Ruiz, 1988a)

En esta fase inician su aparición, dentro de este grupo, las ollas con visera y concavidad interior para el asiento de la tapadera, tipo $3.1\left(\mathrm{n}^{\circ} 38\right)$, las ollas de borde entrante y perfil exterior de sección triangular tipo 4.3, y las cazuelas tipo $11\left(n^{\circ} 41-42\right)$, formas que continuarán a lo largo de todo el siglo vi. No obstante, las formas más características de estos estratos de la primera mitad del siglo vi son las ollas de borde entrante y labio inclinado al interior tipo 4.1 ( $\left.\mathrm{n}^{\circ} 35-36\right)$, la forma 4.3 con el borde entrante y perfil exterior de sección triangular, y las ollas de la forma 4.2, con labio redondeado, que presentan un acabado cuidado y cuyas paredes exteriores llevan estrías marcadas en el torno, ya que aparecen también representadas en los mismos estratos de abandono documentados en el cuerpo de tabernae del complejo comercial (Láiz y Ruiz, 1988b, 282).

En cerámica de cocina destaca un fragmento de tapadera $\left(n^{\circ} 40\right)$ realizada a torno lento y con las superficies bruñidas, que puede pertenecer al grupo
Hand-made individualizado por Fulford y Peacock, fabricado en la isla de Pantelleria entre finales del siglo v e inicios del siglo vi (Fulford, 1984, 159).

En cuanto a los envases anfóricos continúa la forma oriental Keay LIII ( $\left.n^{\circ} 43-44\right)$ cuya presencia se incrementa desde mediados del siglo $v$ hasta el siglo vi, como se constata en Carthago, Tarraco y en numerosos vertederos de la propia Cartagena, y aparece asimismo el tipo de envase africano Keay XLI $\left(n^{\circ} 45\right)$, de origen tunecino y destinado probablemente al transporte de aceite de oliva (Keay 1984, 252). Se trata de un envase cilíndrico de pivote macizo, con cuello corto y borde reentrante de sección triangular y con una concavidad en su parte interior, datado en el cementerio paleocristiano de San Seurin (Bordeaux) a finales del siglo IV-principios del siglo $v$ (Keay, 1984, 255) y con una presencia masiva en el vertedero de Vila-roma del segundo cuarto del siglo v (Remolá y Abelló, 1989, 263). En el grupo de ánforas diversas procedente del Puerto de Classe se incluye un borde de este tipo (8.38) que conserva restos de una inscripción pintada en rojo (Stoppioni, 1983, 146). Probablemente este tipo anfórico sería abundante en la zona costera como atestiguan los seis fragmentos de este tipo documentados en los dragados del Puerto de Mazarrón (Pérez Bonet, 1988, 483). La presencia de un ejemplar en esta fase del teatro, fechada a finales del siglo $\mathrm{v} o$ inicios del s. vi podría prolongar su uso durante la segunda mitad del siglo $\mathrm{v}$, si es que no se trata de un ejemplar residual de la fase anterior.

Nosotros datamos este contexto correspondiente al abandono del complejo comercial a inicios del siglo VI, dada la ausencia de formas características de la segunda mitad de este siglo como los tipos Hayes 91C ó 104C.

\section{Fase 9.2 Rellenos bajo estructuras de la primera mitad del siglo $V I$}

Corresponde a un estrato de relleno sobre el que se levantan las estructuras muy arrasadas pertenecientes a unas habitaciones de carácter doméstico construidas tras el abandono del edifico público anterior. El estrato de relleno se caracteriza por una tierra marrón grisácea con abundantes capas de cenizas, carbones y material cerámico fragmentado. Este nivel se presenta bastante homogéneo en toda la superficie excavada y se deposita sobre el nivel de abandono del complejo comercial. El material aquí estudiado corresponde a las UEs. 4371 y 4372 , localizado bajo una habitación construida sobre la exedra del edificio anterior. 
En este nivel encontramos cerámicas T. S. Africanas Clara D, formas Hayes $61 \mathrm{~B}\left(\mathrm{n}^{\circ} 61\right), 63\left(\mathrm{n}^{\circ}\right.$ 60), 90 (57-58), 91C ( $\left.{ }^{\circ} 52\right), 93 \mathrm{~B}\left(\mathrm{n}^{\circ} 55\right), 80 \mathrm{~B} / 99$ $\left(n^{\circ} 48\right), 99$ B-C ( $\left.n^{\circ} 49-51\right), 104 C$ ( $\left.n^{\circ} 46-47\right)$; aunque la mayoría de estas formas inician su producción en la segunda mitad del siglo $\mathrm{v}$, otras tienen, sin duda, una datación más tardía. La forma 80B/99 aunque está presente en contextos del 475-500 es característica sobre todo en estratos datados entre 525-575 (Fulford, 1984, 71). En cuanto a la 93B está atestiguada en Carthago en estratos de fines del siglo $\mathrm{V}$ (Tortorella, 1987, 305). La forma $104 \mathrm{C}$ es la forma más tardía dentro de este grupo y es datada por Hayes entre 500-625, aunque su cronología inicial quizás pueda retrasarse hasta el primer cuarto del siglo vI, según las estratigrafías de Carthago. Fulford propone una datación entre 530-600 $(1984,74)$. Nosotros proponemos que la datación de nuestro depósito y probablemente de la fase constructiva debe fecharse entre 525-535.

En cerámica de cocina africana se mantienen, en líneas generales, los tipos de la fase anterior (8.1). Destacan dos cazuelas de pátina cenicienta, una perteneciente a la forma Hayes 197 probablemente residual $\left(\mathrm{n}^{\circ} 65\right)$ y otra, la $\mathrm{n}^{\circ} 66$, asimilable a Atlante I, CVII, 5-7, datadas entre el siglo IV y vI, y continúa la presencia de morteros con visera ( $\mathrm{n}^{\circ}$ 63-64) del grupo 2 de Fulford (1984, fig. 76.2). Paralelamente, siguen los cuencos de pastas claras $\left(n^{\circ} 67\right)$ relacionables con la forma 21.1 de Vegas (1973, 21, fig. 20) que en este caso concreto, y frente a los ejemplares de la fase anterior, pueden adscribirse más bien a un uso funcional de copa que de cuenco así como los platos de fondo anular ( $\left.\mathrm{n}^{\circ} 68\right)$ y las jarritas monoansadas próximas a la forma Vegas $43\left(\mathrm{n}^{\circ}\right.$ 69). Las botellas o jarras de cuello estrecho, asimismo de procedencia norteafricana, muestran morfológicamente estrecho paralelismo con los tipos $19.1 \mathrm{y}$ 2 de Fulford, con borde exvasado de sección triangular ligeramente moldurado ( $\mathrm{n}^{\circ} 70$ ) (Fulford y Peacock, 1984, 209, fig. 80), y 43.2 con el cuello ligeramente moldurado y borde no diferenciado $\left(\mathrm{n}^{\circ} 72\right)$ (Fulford y Peacock, 1984, 211-213, fig. 82), fechados por este autor entre el 475-500. Hay también gran variedad de morteros: con visera más o menos acentuada $\left(\mathrm{n}^{\circ} 73,74\right.$ y 76$)$, emparentados con la forma W1, tipo 19 de Reynolds (1993, 105-107, lám. 12 ss.) fechada entre finales del siglo $v$ y mediados del siglo vi o decorados con ondulaciones sencillas a lo largo de la visera y con impresiones en el borde $\left(\mathrm{n}^{\circ} 75,77\right.$ y 78$)$ próximos a la forma W1.20 de Reynolds, que en el valle del Vinalopó ofrece una datación similar a los anteriores.

Otros recipientes documentados son grandes va- sijas de almacenaje, emparentadas con la forma Vegas 12 , de un diámetro que oscila entre los 272 y los $300 \mathrm{~mm}$., y pastas depuradas de color anaranjado con inclusiones de pequeñas partículas blancas y superficie exterior engobada $\left(\mathrm{n}^{\circ} 79-80\right)$. La primera $\left(n^{\circ} 79\right)$ con el borde exvasado de sección triangular que cae en una pequeña visera, corresponde a la forma W1, 24B (Reynolds, 1993, 108, lám. 19) ilustrada por este autor con dos ejemplares fechados en el siglo $\mathrm{v}$, mientras que la segunda $\left(\mathrm{n}^{\circ} 80\right)$, con paralelos en Benalúa y el Monte Benacantil (Alicante), se inserta dentro de la forma W1, 26D (Reynolds, 1993, 108-109, lám. 20) que no dispone de una datación concreta. En general, estas piezas están relacionadas morfológica y funcionalmente con las formas presentadas por Fulford en las láminas 73 y 74 datadas en su práctica totalidad dentro del siglo vI (Fulford y Peacock, 1984, 193-194) fecha que concuerda con los ejemplares de la fase 9.2 que aquí analizamos, 525-535.

En cuanto a las cerámicas de cocina tosca de producción local destaca la continuidad de las ollas de borde entrante, tipo 4 ( $n^{\circ} 85-86$ ), con acabados cuidados, cuyos tipos parecen desaparecer hacia el 550 y continúan en mayor número y variedad las ollas 3.1 ( $\left.n^{\circ} 82-84\right)$, con visera y perfil en $S$, que se manifiestan a lo largo del siglo vi y están ausentes en el nivel de destrucción fechado en la tercera década del siglo vII al igual que la olla 1.2, con pestaña en el borde externo y perfil interior en $S\left(n^{\circ} 81\right)$, que aparece en esta fase y continúa durante las fases 10.4 y 10.5 , fechándose en consecuencia durante todo el siglo vi. Son asimismo frecuentes las cazuelas de los tipos 10 , con el perfil cóncavo-convexo ( $\left.\mathrm{n}^{\circ} 91\right)$, tipo 11 , con la pared media engrosa$\mathrm{da}$, que se distribuye por los niveles de todo el siglo vi y en el nivel de destrucción $\left(\mathrm{n}^{\circ} 90\right)$, y tipo 12 , cazuela de paredes engrosadas ( $\left.n^{\circ} 92\right)$, con un desarrollo en contextos y cronología similar. En líneas generales, agrupamos bajo el término cazuela, una serie de grandes fuentes para cocinar, con un diámetro de la boca que oscila entre los 30 y los $40 \mathrm{~cm}$., bases planas muy engrosadas y paredes poco profundas de entre 5 y $7 \mathrm{~cm}$. de altura. Hace además su aparición el cuenco tipo 5 de borde engrosado al exterior ( $\mathrm{n}^{\circ} 88-89$ ), cuerpo hemiesférico y asa aplicada, que se desarrolla sobre todo a lo largo del siglo vi, entre las fases 9.2 y 10.3 .

En estos niveles se hallan los envases anfóricos de origen africano Keay LXI ( $\mathrm{n}^{\circ}$ 93) y Keay LXII $\left(n^{\circ} 94\right)$, ánforas que tienen una datación inicial en el segundo cuarto del siglo $v$ y que irrumpen masivamente en los circuitos comerciales desde la primera mitad del mismo siglo. La exportación se generali- 
za en el siglo vi en puertos tan significativos como los de Marsella, Tarraco y Carthago. Respecto a la primera, corresponde a un envase de cuerpo cilíndrico rematado en un pivote macizo con un engrosamiento anular, asas de sección elíptica y cuello cilíndrico con borde grueso de sección rectangular. $\mathrm{Su}$ ausencia en contextos claros de la primera mitad del siglo $\mathrm{v}$ como en la necrópolis paleocristiana de Tarragona, las excavaciones del Palatino (Keay, $1984,305)$ o en el vertedero de la muralla de Teodosio en Carthago (Neuru, 1980) hicieron plantearse a Keay una cronología inicial de mediados del siglo v; sin embargo, el hallazgo con posterioridad de dos bordes en el vertedero de Vila-roma (Remolá y Abelló, 1989, 265-266) ha permitido remontar esta cronología a la primera mitad de dicho siglo. Desde mediados del siglo $\mathrm{v}$ se generaliza su importación (Keay, 1984, 309) que se prolonga hasta finales del siglo vi en puertos tan significativos como el de Marsella (Bonifay, 1986, 288). Otros dos ejemplares fechados en el siglo vil se documentan en la iglesia de San Pere y Santa Maria de Terrasa (Keay, 1984, 305) y un pivote en el pecio de Yassi Ada (Bass y van Doorninck, 1982, 185) materiales que son considerados por Keay como residuales. Sin embargo, los hallazgos del teatro de Cartagena, donde este tipo anfórico se repite de forma constante desde principios del siglo vi hasta el primer cuarto del siglo vil, momento en que se fechan los ejemplares completos de la fase 10.2 , permiten matizar la cronología final de este tipo anfórico. A la luz de todos estos datos se puede considerar un marco cronológico para este envase entre el $425 / 450$ para sus inicios y, al menos, el primer cuarto del siglo vII para su desaparición.

Otro envase africano son las anforitas de salazón tipo spatheion ( $\mathrm{n}^{\circ}$ 96-97), que en los niveles del teatro empiezan a aparecer en esta fase, con un diámetro de boca de apenas $60 \mathrm{~mm}$. y que han sido datadas para la tarraconense en el siglo vi. Agrupamos bajo esta denominación un grupo diverso de envases de pequeño tamaño, que carece de uniformidad tipológica (salvo el tamaño más o menos reducido) que tradicionalmente ha sido asimilado a la forma Keay XXVI, aunque dentro de este grupo tan sólo las variantes $\mathrm{C}$ (con el borde exvasado y ligeramente engrosado) y $\mathrm{G}$ (con borde exvasado de sección triangular) se aproximan morfológicamente a las anforillas que nos ocupan. En consecuencia, consideramos más acertada para nuestros ejemplares la denominación Beltrán 65 o «carrot Shaped» (Hayes, $1968,215)$ utilizada para definir un conjunto de anforillas de salazón de pequeño tamaño, con borde engrosado de sección triangular, con pequeñas asas y pivote cilíndrico y macizo, cuyo diámetro oscila entre los 59 y $66 \mathrm{~mm}$., siendo la media de $60 \mathrm{~mm}$. Tradicionalmente se ha considerado un origen africano para estas manufacturas, aunque se han documentado producciones de características similares a las descritas en el puerto de Classe (Stoppioni, 1983, 133) así como en Águilas y Puerto de Mazarrón, en el litoral murciano, datadas éstas últimas entre mediados del siglo Iv y la primera mitad del siglo v (Ramallo, 1985, 440). En este sentido, Beltrán $(1970,571)$ plantea una amplia cronología que abarcaría desde el siglo IV al viI, mientras que Keay $(1984,216)$ sugiere una datación tardía para sus variantes XXVI C y G. Por otra parte, ejemplares idénticos a los de Cartagena se documentan en los depósitos de Saraçhane (Hayes, 1968, 215) de finales del siglo vI-principios del vII y en el pecio de Yassi Ada a principios del siglo viI. Se trata en conclusión de un grupo heterogéneo que tiene distintos centros de producción y una cronología amplia que cubre un amplio espectro, con distintas matizaciones, entre los siglos IV y viI.

Paralelamente a la introducción de estos nuevos tipos, continúa la llegada de ánforas orientales tipo Keay LIII ( $\left.n^{\circ} 100\right)$ que aumentan en número desde mediados del siglo $v$ y durante el siglo vi en contextos de Carthago, Tarraco y Cartagena, y hace su aparición el envase tipo LXV/LRA 2 ( $\mathrm{n}^{\circ}$ 99), de origen controvertido aunque muy probablemente también oriental, que si bien está documentado en el siglo IV en el Ágora de Atenas (Robinson, 1959, tipo M.272) su introducción en occidente no se hace efectiva hasta el segundo cuarto del siglo $\mathrm{v}$, tal como reflejan los escasos ejemplares del Vertedero de Vila-roma (Remolá y Abelló, 1989, 278-279) y el templo de la Magna Mater en Roma (Carignani, 1986), si bien en estas fechas todavía está ausente en el período 1 de la Bourse de Marsella, fechado a mediados del siglo v (Bonifay, 1986, 279-282) y en el Muro de Teodosio en Carthago fechado entre el 425-475 (Neuru, 1980 , 195-211). Precisamente en Carthago no se documenta hasta finales del siglo $\mathrm{v}$, teniendo su período de máxima difusión, según Peacock $(1984,119)$ en la primera mitad del siglo vi, concretamente entre el 525-535, fecha a partir de la cual comienza un período de paulatina decadencia, con escasos ejemplares de finales del siglo vi en Carthago (Riley, 1982, 103) y en el período $2 \mathrm{~B}$ de La Bourse (Bonifay, 1986, 290), siendo su presencia residual en contextos del siglo vII (Peacock, 1984, 119). Los ejemplares del teatro romano distribuidos entre las fases 9.1 y 9.2 corresponden a la primera mitad del siglo vi, coincidiendo con el momento de máxima difusión de esta forma en Carthago. 
Fase 9.1 Colmatación de las estructuras de la primera mitad del siglo $\mathrm{VI}$

Corresponde a los estratos de colmatación y abandono de las habitaciones tardías pertenecientes a una fase intermedia entre el abandono del mercado y la construcción del barrio bizantino. Se caracteriza por una tierra de color marrón claro con piedra menuda y escaso material cerámico.

En él encontramos asociados vasos de T.S. Africana Clara D, formas Hayes 99C $\left(n^{\circ} 101-103\right)$ y 104 $\mathrm{C}\left(\mathrm{n}^{\circ} 104\right)$, características del siglo vi avanzado y ya presentes en el nivel anterior. Destaca en este mismo contexto una lucerna africana Hayes IIB con motivos cristianos ( $\left.\mathrm{n}^{\circ} 105\right)$ : peces en el margo y en el disco figura de un santo portando en su mano derecha una cruz, decoración perteneciente al estilo E (ii) datado a partir del año 525 (Atlante I, 134135).

En cerámica de cocina africana contamos con un fragmento de mortero con visera $\left(n^{\circ} 108\right)$ asimilable al grupo 2 de Fulford, forma también presente en el nivel anterior, que se tiende a fechar entre el 500600 , pero con un momento de esplendor hacia el 525 (Fulford, 1984, 199-200).

En cerámica común de producción indeterminada continúan presentes las jarras con el borde ligeramente exvasado, una pequeña concavidad en su interior, moldura exterior y engobe exterior de color beige-amarillento ( $\mathrm{n}^{\circ}$ 106-107), asimilable a la forma Vila-roma 6.116 (TED'A, 1989, 222-223).

En cerámica de cocina tosca de producción local destaca la aparición de las tapaderas de borde redondeado, tipo $14.2\left(\mathrm{n}^{\circ} 109\right)$ y la continuidad de las cazuelas tipos 11 y $12^{\circ}\left(\mathrm{n}^{\circ} 110-111\right)$.

En cuanto a los envases anfóricos continúan los mismos tipos que en la fase anterior. Por una parte, las producciones orientales con la forma Keay LXV ( $\mathrm{n}^{\circ}$ 113-114), que, como ya hemos señalado, comienza su difusión en el Mediterráneo occidental a partir del segundo cuarto del siglo $v$ hasta finales del mismo siglo en que hace su aparición en Carthago, teniendo un período de máxima difusión en la primera mitad del siglo vi. Por otra parte, también está presente una representación de los grandes envases africanos tipo Keay LXI $\left(n^{\circ} 115\right)$ que van a tener una importante presencia desde la primera mitad del siglo $\mathrm{v}$, generalizándose su difusión en el siglo vi en Marsella, Tarraco y Carthago. Es un ánfora de cuerpo cilíndrico rematado en un pivote macizo con un engrosamiento anular, asas de sección elíptica y cuello cilíndrico con borde grueso de sección rectangular.

\section{Fase 10.5 Rellenos de la fase fundacional del} barrio bizantino

Corresponde a los niveles de relleno fundacionales sobre los que se construye el que hemos denominado barrio de época bizantina. Concretamente los materiales estudiados aquí pertenecen al relleno fundacional de una estancia triangular exterior (espacio 5) común a las habitaciones 2 y 3 de este barrio.

En este nivel hacen su aparición las formas más tardías de la T.S. Africana Clara D, Hayes 103, 105, 107 y continúa la 99C. Hayes $(1972,169)$ sitúa la fabricación de la forma 105 entre 580/600-660, Fulford adelanta algunos años el inicio de la producción que se iniciaría según el autor hacia el 550 (Fulford 1984, 74) e incluso aparece también en contextos de la primera mitad del siglo vI, como en la Schola Praeconum (Whitehouse et alii, 1985, 179-181), y en la basílica de Fornells (Menorca) entre un conjunto de materiales fechados entre mediados del siglo v e inicios del siglo viI (Navarro, 1982, 443). Se halla documentada en las necrópolis lombardas de Castel Trosima y Nocera Umbra, fechada entre el último cuarto del siglo vi y el siglo viI (Baldassare, 1967, 141). Al mismo tiempo, está también atestiguada en Carthago en niveles del siglo viI. En cuanto a la forma Hayes 103, se ubica, según la mayoría de autores, entre el 500 y el tercer cuarto del siglo vi (Hayes, 1972, 160, Atlante I, 9899). En Carthago aparece en contextos de fines del siglo v-mediados del s. vi (Tortorella, 1987, 306). La forma Hayes 107 está datada, según las estratigrafías de Carthago, a partir del 550 con un alto porcentaje hacia 575 (Fulford, 1984, 74). Hayes $(1972,171)$ por el contrario propone una fecha más tardía, situada entre el 600 y el 650. También de producción africana encontramos en este nivel un fragmento de lucerna con decoración estilo $\mathrm{E}$ (ii) datable a partir del siglo vi (Atlante I, 132).

En cerámica común hay una numerosa representación de jarras $\left(\mathrm{n}^{\circ} 123-128\right)$ con sencillos bordes exvasados y producción indeterminada asimilables a la forma Vegas 40. Asimismo se documentan varios morteros con visera ( $\left.\mathrm{n}^{\circ} 129-132\right)$. Uno de ellos presenta el fondo con incrustaciones de piedrecillas abrasivas ( $\left.n^{\circ} 133\right)$, con las mismas formas que en la fase anterior datábamos según paralelos con el Valle del Vinalopó entre finales del siglo v y mediados del siglo vi d. C. Otro elemento a considerar son las grandes vasijas de almacenaje $\left(n^{\circ} 134-136\right)$ con paralelos en Benalúa, donde presentan una cronología en torno al siglo vi d. C. (Reynolds, 1993, 108-109, lám. 20). 
En cuanto a las cerámicas de cocina destacan por una parte las producciones locales, especialmente las ollas tipo 1.4, con borde moldurado al exterior y perfil interior redondeado, al tiempo que continúan las ollas con concavidad interiór 3.1, así como las cazuelas tipos 11 y 12 . También en este contexto aparece una forma nueva definida como tipo 2.4 caracterizada por el borde vuelto y engrosado al exterior, con cuerpo de tendencia globular y pitorro vertedor. Asimismo se introducen las tapaderas de borde alzado, tipo 14.1 ( $\left.\mathrm{n}^{\circ} 139\right)$, documentadas en los estratos de la segunda mitad del siglo vi (fases 10.5 y 10.4).

Junto a ellas destacan las producciones importadas de la isla de Pantelleria caracterizadas por sus acabados bruñidos y fechadas a partir del siglo vI $\left(n^{\circ} 143-145\right)$.

En las ánforas se aprecia un notable desarrollo en el comercio con envases africanos de los tipos Keay LXI ( $\left.n^{\circ} 148\right)$ y Keay LV ( $\left.n^{\circ} 147\right)$, así como de las anforillas africanas tipo Keay XXVIG, spatheion $\left(\mathrm{n}^{\circ} 152\right)$, formas todas ellas ampliamente representadas en los contextos del siglo vi. También se documentan envases de procedencia oriental, como la forma Keay LIII ( $\mathrm{n}^{\circ} 150-151$ ), que se difunde ampliamente durante el siglo vI.

A partir de estos datos proponemos para la fecha de construcción de este barrio el período comprendido entre los años 550-570 d.C.

\section{Fase 10.4 Pavimentos y preparados de} pavimentos de la fase fundacional del barrio bizantino

Corresponde esta fase a los suelos y sus preparados pertenecientes al período inicial del barrio bizantino y concretamente al pavimento de la habitación 5. Se caracteriza por un suelo de tierra apisonada de 3 a $5 \mathrm{~cm}$. de espesor con una capa inferior de nivelado y preparación. Como fósiles directores para fechar este momento contamos con la presencia de africana D, en sus formas 99C, 104C y 105 , lo que permite datar dichos pavimentos entre 570-590 d.C.

En cuanto a la cerámica de cocina tosca de producción local continúan fabricándose las ollas de borde engrosado al exterior de los tipos 1.2, 1.3, 1.4 y el cuenco tipo 5.

Respecto a las ánforas se observa una clara continuidad de la fase anterior, con la presencia de envases africanos Keay LXIIB ( $\left.{ }^{\circ} 172\right)$ y anforillas tipo spatheion, Keay XXVIG ( $\mathrm{n}^{\circ} 173$ y 174) datadas principalmente en el siglo vI.
En cerámica común continúa la presencia de los cuencos tipo Vegas $20\left(\mathrm{n}^{\circ} 162\right)$ y destaca sobre todo una botella de cuello estrecho y alargado $\left(n^{\circ} 160\right)$ de posible producción ebusitana asimilable a la forma RE-0204B (Ramón, 1986, fig.7) fechada entre el 550 y el 700 . En el teatro hemos localizado dos fragmentos de borde e inicios del cuello decorados con incisiones, idénticos tipológica y técnicamente, pero documentados en fases distintas. El primero de ellos en la fase 8.2, corresponde a la primera mitad del siglo $v$, lo que atrasa la cronología tradicional de este envase, mientras que el otro ejemplar, incluido en la fase 10.4-10.5, es de la segunda mitad del siglo vi y coincide plenamente con la datación de los ejemplares catalanes, ibicencos y norteafricanos.

\section{Fase 10.3 Pavimentos y preparados de pavimentos del nivel anterior}

En esta fase incluimos los pavimentos y sus preparados correspondientes al momento de destrucción de las habitaciones del barrio bizantino. El área objeto del presente estudio abarca las estructuras de una zona exterior (espacio 5) interpretada como una calle de acceso en codo desde la zona baja del barrio instalada sobre los itinera y el proscaenium y la parte alta articulada sobre la antigua ima cavea. Por esta calle acodada se llega a un patio de forma triangular (estancia 4) donde se localizó un horno, una pileta y un banco adosado y que comunica directamente con las habitaciones 2 y 3 . Los pavimentos interiores están realizados con arcillas rojizas endurecidas de 3 a $6 \mathrm{~cm}$. de espesor (UEs. 4301, 4307) mientras que los suelos que cubren los espacios exteriores se caracterizan por una capa apisonada sobre una gravilla muy compacta de $7 \mathrm{~cm}$. de grosor (UEs. 4304, 4327), bajo los que se asientan pequeñas capas de preparación y nivelación de los pavimentos (UEs. 4354 y 4364). El estudio cerámico del material asociado nos data el último momento de remodelación del barrio donde se realizaron diversas reestructuraciones dentro de las habitaciones y nuevas compartimentaciones.

En este estrato hemos constatado la presencia de terra sigillata africana D Hayes 99C, 104C, 105, 93/ 108 y 109. Algunas de estas formas estaban ya presentes en niveles anteriores y continúan hasta finales del siglo vi y principios de s. vII. En este nivel aparece por primera vez la forma Hayes 109 considerada por la mayoría de autores como cerámica de cocina africana con decoración de bandas bruñidas. Es una de las producciones más modernas de las oficinas tunecinas, para la que Hayes propuso una cronología 
del 580/600-650 (1972, 172) aunque posteriormente este mismo autor ha centrado su producción entre el 610/620-670/700 (1980, 517). En la Bourse de Marsella se halla representada en el Período 2B, fase $3 /$ 4, aunque está presente de forma casi testimonial en las fases 1 y 2 (Bonifay, 1983, 317-320). Parece claro por las estratigrafías de Carthago que el inicio de su producción debe centrarse en el primer cuarto del siglo vil (Michigan IV, 93-94). En la Península Ibérica sólo aparecen documentadas, que sepamos, en Tarragona (Járrega, 1987, 340), Cartagena (Méndez y Ramallo, 1985, 243) y en Belo, con ligeras variantes respecto a los prototipos reproducidos por Hayes (Bourgeois y Mayet, 1991, 309, lám. CIII). En cuanto al fragmento $\mathrm{n}^{\circ} 180$ resulta difícil su adscripción a la forma 93B, 94B o 108 de Hayes. De cualquier forma su cronología debe centrarse en la segunda mitad del siglo vi o inicios del viI.

En la cerámica común continúan los morteros con visera $\left(n^{\circ} 186\right)$ y ondulaciones $\left(n^{\circ} 188\right)$, de posible producción africana, destacando un mortero $\left(\mathrm{n}^{\circ} 187\right)$ decorado con impresiones en la visera de pasta similar a la producción tosca local. Aparecen las jarritas de cuello estrecho y moldurado (n.183 y 184), de producción africana y asimilables a los tipos 4 y 5 de Fulford, datados en el siglo vi (Fulford, 1984, fig. 79.4-6).

La cerámica tosca de producción local muestra un amplio porcentaje respecto a los restantes grupos cerámicos y en ella podemos señalar una continuidad de los modelos en sus distintas variantes de la forma 3, bien la olla con visera y escalón interior de la forma $3.2\left(\mathrm{n}^{\circ} 192\right.$ y 195$)$ o bien la variante 3.3 con visera y perfil interior redondeado $\left(\mathrm{n}^{\circ} 191\right)$, las cazuelas tipos 11 y 12 y el cuenco tipo 5 con asa aplicada. La olla de borde entrante tipo 4 parece tener ya un carácter residual en estos estratos dado el escaso número de ejemplares con que está representada.

En este nivel destaca un amplio porcentaje de ánforas orientales Keay LIII ( ${ }^{\circ}$ 204, 205, 209 y 210 ), ya comentadas anteriormente, cuya cronología inicial parte de mediados del siglo $\mathrm{v}$, con una mayor difusión a lo largo del siglo vi, perviviendo hasta inicios del siglo vII, como se ha documentado ampliamente en el pecio de Yassi Ada I (Bass, 1982, 155-156 y Tortorella, 1981, 369). También están presentes las producciones africanas, tanto los grandes contenedores tipo Keay LXI-LXII ( $\mathrm{n}^{\circ} 214$ ) como las anforillas de salazón tipo spatheion con borde semicircular, tipo Keay XXVIC ( $\left.\mathrm{n}^{\circ} 211\right)$, y con borde moldurado, tipo Keay XXVIG ( $\mathrm{n}^{\circ} 212$, $213)$, cuya pervivencia se ha marcado tradicionalmente a finales del siglo vi, considerando como residual su presencia en contextos del siglo viI.

\section{Fase 10.2 Nivel de destrucción del barrio} bizantino

Corresponde al nivel de destrucción localizado en las habitaciones del denominado barrio bizantino anteriormente reseñadas. Este nivel se caracteriza por un potente estrato de disoluciones de adobe procedente del alzado de las paredes entremezclado con finas capas de disoluciones de esquistos utilizadas como aislante en las cubiertas de las habitaciones y abundante carbón vegetal. Este nivel cubría los ajuares domésticos de cada estancia aplastados sobre los suelos de las mismas. Nos encontramos sin duda ante el momento de destrucción visigoda mencionado por San Isidoro y que debemos fechar hacia el 620-625. En esta vivienda se han podido individualizar tres espacios distintos correspondientes a una cocina, almacén y patio/espacio descubierto con materiales cerámicos de distinta naturaleza según la función de cada uno de ellos.

La habitación 3, destinada a usos domésticos contenía una olla tipo 1.1 y una cazuela de la forma 13, mientras que la habitación 2, usada probablemente como almacén, se caracterizaba por la presencia de ánforas Keay LXI (7 ejemplares completos) y XXXII (2 ejemplares completos) que se hallaban adosadas en origen contra la pared a cuyo pie aparecieron desplomadas.

Estas habitaciones abren a un espacio común de forma triangular donde han sido identificadas ánforas africanas y cerámicas de cocina.

En este nivel de destrucción tenemos documentadas las formas de africana D Hayes 99C, 91D, 105, $93 / 108$ y 109 , formas presentes, en su mayor parte, en el estrato anterior, a las que hay que añadir la forma 91D, la variante más tardía de la forma 91, para la que Hayes propuso una cronología central entre el 600 y 650 . Aunque Fulford considera que los primeros ejemplares podrían datarse en la segunda mitad del siglo vi $(1984,65)$, parece más adecuado, dada su ausencia en algunos contextos del siglo vi como el de Benalúa (Reynolds, 1987, 30) que se trate de una forma característica de la primera mitad del siglo vir. Aparece en la Bourse de Marsella, Período 2B, fase $3 / 4$, junto a platos Hayes 90B, 99C, 105, 107 y 109 , en un contexto fechado en la primera mitad del siglo vII (Bonifay, 1983, 320-322) y, en Porto Torres, en la fase vi, capa de abandono junto a un plato Hayes 107 (Villedieu, 1984, 75).

En las cerámicas de cocina de producción africana destaca la forma Hayes 197, aunque su presencia podría ser residual, y un mortero con visera $\left(n^{\circ} 247\right)$ perteneciente al grupo 3 de Fulford representado en Carthago en contextos entre el 575 y el 
625-650 (Fulford, 1984, 198-200). También de procedencia africana destaca un oinochoe con bandas paralelas incisas en el cuello $\left(\mathrm{n}^{\circ} 217\right)$ asimilable al Grupo 9 de Fulford (Fulford y Peacock, 1984, 207, fig. 79.9.2) datable en el siglo vi y un borde exvasado con marcado estrechamiento en el cuello de una botella/jarra asimilable a la forma 56.1 de Fulford (1984, 213, fig. 83) fechado entre los siglos VI-viI.

La cerámica tosca de producción local se caracteriza en estos niveles por su aspecto más grosero y sobre todo por la aparición del modelado a mano. Desaparecen las ollas 3.1 con viseras bien señaladas en el torno y aparecen las ollas forma 1.1, caracterizadas por el borde engrosado al exterior y perfil interior en $S$, realizadas a torno lento y con acabados toscos, presentes sobre todo en los niveles de destrucción y abandono de la fase 10.1 y 10.2 , fechadas en la primera mitad del siglo viI. También es frecuente en estas fases el cuenco de borde entrante engrosado al interior, forma $7 \mathrm{y}$, asimismo, aparece en este contexto una forma nueva, la forma 13 , cazuela modelada a mano, con paredes verticales exvasadas, labio plano, asas de lengüeta horizontal de forma lunar y base plana. Esta forma, aunque con distintas pastas aparece documentada en yacimientos alicantinos y es asimilable a las formas 7.6 y 9.3 de Reynolds (1985) fechadas entre los siglos vi al viII. También en cerámica tosca pero de producción indeterminada contamos con una olla completa $\left(n^{\circ} 251\right)$ asimilable a las formas Reynolds 7.7 y 8.1 datables en los siglos VI-VII y ollas de producción local con el borde vuelto moldurado, forma 2.2 $\left(n^{\circ} 219\right.$ y 236).

En cuanto a los envases anfóricos, se constata la presencia de dos ejemplares de la forma Keay LIII que consideramos en su mayoría residuales debido a su reducido diámetro, pudiendo señalar como contemporáneo de esta fase tan sólo un borde de $122 \mathrm{~mm}$. de diámetro. Asistimos, en consecuencia, a un retroceso de las importaciones orientales, ya señalado por Peacock para comienzos del siglo viI, que quizás haya que vincular con la conquista persa de estas regiones y desde luego la posterior conquista árabe desde el 635.

Por el contrario se documenta un intenso comercio con el norte de África, especialmente con la región tunecina, del que es un claro reflejo el almacén de ánforas arriba reseñado, donde en el momento de su destrucción contaba con envases africanos de la forma Keay LXI ( $n^{\circ} 223,224,225,225$ bis, 226, 238, 239, 240, 242, 245), dos bordes de Keay LXII $\left(n^{\circ} 252\right.$ y 253$)$, uno de ellos ( $\left.n^{\circ} 252\right)$ con bandas de decoración incisa a peine en el cuello y un grafito inciso completo en el hombro con el texto: $P E C U$ LIA, y dos ejemplares - uno de ellos completo- de la forma Keay XXXII ( $\left.{ }^{\circ} 221,222\right)$, sistematizado por este autor tan sólo a partir de tres bordes. Se trata de un envase de cuerpo cilíndrico, con asas pequeñas que unen el cuello con la parte alta del hombro del ánfora, pivote macizo y engrosado en la punta; cuello cónico apenas marcado y borde engrosado de sección triangular y ligeramente moldurado. El diámetro de los dos bordes hallados en este nivel es de $98 \mathrm{~mm}$., sensiblemente menor a la media propuesta por Keay de $131 \mathrm{~mm}$.; no obstante este dato no nos parece muy significativo puesto que otro ejemplar idéntico morfológica y técnicamente a los dos anteriores, documentado en un vertedero del Molinete (Cartagena), presenta un diámetro de 110 $\mathrm{mm}$. Respecto a su origen, no hay evidencia directa, pero en base a la fábrica y a la similitud con la forma XXV, se le supone un origen tunecino (Keay, 1984, 231). El contenido es desconocido. La datación propuesta por Keay, según uno de sus prototipos oscila entre el siglo IV-mediados siglo v d.C., considerando residual otro ejemplo documentado en contextos de finales del siglo vi d.C. Sin embargo este último dato se ha de modificar en base a las dos ánforas documentadas en Cartagena, en la fase 10.2, que nos remiten a un momento claro de uso a principios del siglo viI. Uno de ellos $\left(\mathrm{n}^{\circ} 221\right)$ presenta un grafito completo inciso, con el texto $M X X$. Esta misma cronología se confirma con tres ejemplares de Benalúa asociados a africanas $\mathrm{D}$, de las formas Hayes 101, 102, 103, 104, 106 y 107 así como a Late Roman C y D. Otro ejemplar de La Alcudia aparece vinculado a las formas de Africana D, Hayes 103 y 104 (Reynolds, 1993, lám. 89 y 112).

A esta fase se asocia también un ánfora completa de tamaño intermedio, cuerpo globular de tendencia ovoide y fondo rehundido, hombro poco marcado $\mathrm{y}$ asas de sección elíptica, con el cuello cilíndrico de borde engrosado y ligeramente moldurado que presenta una banda acanaladada debajo de las asas que rodea todo el vaso. Forma CP-4310$157 / 6$. Tiene un diámetro en el borde de $86 \mathrm{~mm}$. y un diámetro máximo de $283 \mathrm{~mm}$; la altura máxima estimada es de $465 \mathrm{~mm}$. El parentesco morfológico evidente con los tipos Yassi Ada 1, variante tardía del ánfora Keay LIII, y Yassi Ada 2 (Bass y Van Doorninck, 1982), nos hacen pensar que el ejemplar que nos ocupa tiene una clara filiación con el Mediterráneo oriental, ya sea en el área del Mar Negro o en Thasos, Chios y Constantinopla y con un contenido probablemente vinario (Bass y Van Doorninck, 1982, 163-165). Esta hipótesis de procedencia oriental estaría avalada por la similitud con otro 
tipo anfórico procedente de un complejo termal de Histria (Beltrán,1970, fig. 239, 5). Estas ánforas no tipificadas pero con indudable afinidad tipológica con la Keay LIII aparecen también en el pozo tardío de la villa de Torre Llauder, asociadas a Keay LXI y LXII, en un contexto fechado en el siglo vI (Clariana y Járrega, 1994, 264-265, fig. 21).

Desde el punto de vista cronológico, todos los ejemplares analizados son sincrónicos: las ánforas del pecio de Yassi Ada se fechan puntualmente en torno a los años 625-626 d.C.; el ejemplar de Histria se ubica entre los siglos vI-VII, mientras que en Cartagena, la aparición de este envase en la fase 10.2, nos conduce al primer cuarto del siglo viI.

En su conjunto, este material representa en la actualidad el contexto más tardío, que sepamos, para estas producciones.

\section{Fase 10.1 Nivel de abandono del barrio bizantino}

Corresponde al estrato de abandono y colmatación de este barrio caracterizado por la presencia de numerosos derrumbes procedentes de los muros y de arcillas anaranjadas y limos muy lavados producto de la exposición prolongada de los restos a la intemperie.

Este nivel ofrece un contenido cerámico escaso y fragmentado muy similar al del contexto de destrucción. En él están presentes las formas de africana $\mathrm{D}$, Hayes $99 \mathrm{~B} / \mathrm{C}\left(\mathrm{n}^{\circ} 256\right)$ y 105 ( $\left.\mathrm{n}^{\circ} 257\right)$, así como cerámica de cocina africana con pátina cenicienta ( $n^{\circ} 258$ ) (Atlante I, 108,4) hallada también en Carthago en el contexto de los siglos VI y VII (Fulford y Peacock, 1994, fig. 4,5.20).

Respecto a la cerámica común hay representadas dos jarras, una de las cuales, monoansada y de borde moldurado ( $\mathrm{n}^{\circ} 259$ ), es asimilable a tipos datados en el siglo $\mathrm{v}$, por lo que la consideramos residual; la otra ( $\left.n^{\circ} 260\right)$ continúa las pautas de cerámicas semejantes en fases anteriores.

En las cerámicas toscas de producción local continúan las ollas forma $2.2\left(\mathrm{n}^{\circ} 261\right)$ y el cuenco de borde reentrante forma 7 ( $\left.\mathrm{n}^{\circ} 262\right)$ característicos de este momento final.

\section{VALORACIÓN GLOBAL}

Hay que señalar como advertencia previa que el material que aquí se ha analizado constituye una muestra, significativa pero al mismo tiempo reducida, del conjunto total de materiales cerámicos de es- tas fases halladas durante las campañas de 19881995. Consideramos en consecuencia que, si bien globalmente los contextos quedan bien definidos y representados con los ejemplares reseñados, podrán enriquecerse notablemente, con la incorporación de nuevas formas o variantes de las ya analizadas, cuando se termine el inventario y estudio de todo el material de las campañas de 1994 y 1995. Debe en consecuencia considerarse este trabajo como un punto de partida, y de reflexión, en la sistematización de los contextos tardíos (ss. IV al vII) excavados en el teatro romano de Cartagena.

El primer hecho que destaca tras el análisis de los contextos tardíos procedentes de los niveles superiores del teatro romano de Cartagena, es el importante papel que durante los siglos $\mathrm{V}$ al vII juega la ciudad portuaria como gran puerto comercial de la Hispania meridional, especialmente levantina, y como centro importador y redistribuidor de distintas manufacturas y productos fabricados y elaborados en distintos puntos del Mediterráneo central y oriental. Continúa con ello una tradición muy arraigada desde época tardo-republicana y confirmada por el conocido texto de Estrabón (III, 4, 6). El fuerte incremento de la actividad comercial desde mediados del siglo IV y, sobre todo durante los siglos vi y principios del vir se refleja, no sólo en los niveles tardíos de las excavaciones del teatro, sino también en otros puntos de la ciudad como los de la calle de la Soledad, Molinete y Plaza de los Tres Reyes donde son muy abundantes, junto a los tipos de ánfora mencionados, los tipos de Africana D, Hayes 91D, 99C, 104C, 105, 107, 93/108 y 109 (Méndez, 1985 y 1988), que caracterizan los niveles de época bizantina en el norte de Africa (Tortorella, 1986, 219).

Se puede hablar, en consecuencia, de una continuidad lineal en la importación de las producciones africanas ya que prácticamente están presentes en la ciudad, y en su mayor parte en los niveles tardíos del teatro, todos los tipos fabricados entre el siglo IV y principios del siglo vir. Esa continuidad, que ya vislumbramos en un trabajo preliminar (Méndez y Ramallo, 1985), ha sido luego confirmada por nuevos hallazgos en la ciudad y por otros autores para otros puntos del litoral peninsular (Járrega, 1991; Aquilué, 1992). Paradójicamente, y de momento, son precisamente los tipos más antiguos, las formas propias del siglo IV, las que proporcionalmente muestran una menor representación. En este sentido, no parece que exista, en ningún momento, o al menos durante períodos de larga duración, una interrupción en la importación de las vajillas de mesa africana al litoral hispano que continúan arribando, al menos al puerto de Carthago Nova y muy proba- 
blemente a otros como el de Tarraco, hasta sus últimas producciones. La presencia de este material tan tardío sirve para matizar la hipótesis de algunos autores que consideran el cese de las importaciones a los mercados occidentales desde finales del siglo vI (Tortorella, 1986, 220, carta 8).

Por el contrario, fuera del núcleo urbano estas formas son escasas. Salvo excepciones como Begastri (Ramallo, 1984, 69), Orihuela, Benalúa, Monte Benacantil (Reynolds, 1993, 22) o, en menor medida Aljezares (Ramallo, 1991, 301), los yacimientos tardorromanos conocidos, algunos con abundantes producciones africanas de los siglos IV y $\mathrm{v}$, carecen de las formas típicas de los siglos vi e inicios del vir. Desconocemos de momento, si esta ausencia es consecuencia de la desaparición del hábitat en esos enclaves, o si bien es por causa de una interrupción en el comercio del producto, bien por un empobrecimiento de sus habitantes - como parecen a veces indicar algunas necrópolis rurales del campo de Lorca (Martínez, 1991)—, bien por la interrupción de las vías y mecanismos comerciales en el interior o bien por el desplazamiento de estos núcleos fuera de las tradicionales vías de comunicación. De todas formas es todavía muy poco lo que conocemos sobre las características y emplazamiento del hábitat extraurbano durante los siglos VI y vII, sobre su evolución y sobre la cultura material asociada a estos asentamientos (vid. las síntesis más recientes sobre el poblamiento en general en Gutiérrez, 1988). En este sentido es muy significativo también el hallazgo en el Corralón (Los Belones, Cartagena), en un enclave que controla las minas de Portmán, de producciones africanas Hayes 99, 101, 104 y 109, junto a cerámicas toscas de producción local características del siglo VI.

Por otra parte,y dentro de la misma ciudad, asociaciones similares a las de los contextos analizados del teatro fechados en la segunda mitad del siglo vi se manifiestan en la misma Cartagena. Así, del vertedero de la $\mathrm{C} /$ Duque 33 proceden seis ejemplares de africana D, Hayes 99C, dos platos Hayes 101 junto a ánforas orientales Keay LIII, LXVI y ánforas africanas Keay XXXVA (Láiz y Berrocal, 1991). Por otra parte, la asociación del plato Hayes 104C y ánforas Keay LXII se refleja en el estrato IIb del vertedero de la calle Palas, mientras que en el estrato IIc, la forma $104 \mathrm{C}$ se halló asociada a ánforas Keay LIIIA, LIV y LVA (Roldán et alii, 1991). En ambos contextos las cerámicas toscas de cocina son muy abundantes.

Es muy significativo, por otra parte, el incremento continuo, porcentual y en variedad formal, de las producciones toscas de carácter local o regional, que en gran medida vienen a sustituir las importaciones de cerámicas africanas que prevalecen en contextos de los siglos anteriores. Así, y por poner tan sólo un ejemplo, en los niveles de abandono de la calle Jara 12, fechados a finales del siglo II, la cerámica africana de cocina representa un $39,7 \%$ frente a un $11,1 \%$ de la cerámica local reductora. Por el contrario, en los contextos tardíos este porcentaje se invierte y frente a un $4 \%$ de las africanas, la cocina tosca local supone un $24,4 \%$.

En nuestros contextos, la aparición de estas cerámicas toscas se produce en la fase 8.1, que corresponde al último cuarto del siglo v-inicios del siglo VI, con la introducción de las primeras cazuelas y ollas de superficie exterior cuidada, y que en las últimas fases de principios de siglo vII, con unas superficies mucho más toscas y realizadas a torno lento o modeladas a mano, representan frente a las restantes producciones de mesa el mayor porcentaje, con la incorporación de nuevas formas como la cazuela, forma 13, con asa de lengüeta horizontal que preludia y es el antecedente inmediato de las formas características de pleno siglo vil y de las marmitas islámicas de los siglos VIII y IX.

En conjunto, las cerámicas de cocina tosca local suponen un $24,4 \%$ del material exhumado; de este porcentaje, un $49,9 \%$ pertenece a ollas, un $34,3 \%$ a cazuelas, un $7,8 \%$ a cuencos y un $7,8 \%$ a tapaderas. En consecuencia, ollas y cazuelas son las formas de cocina más numerosas. Entre las ollas, las formas más frecuentes son las de borde engrosado y cuello marcado, forma Cartagena 1, que comienzan a fabricarse a inicios del siglo vi y continúan con modelos cada vez más toscos hasta la fase final del barrio bizantino. Otra forma muy abundante son las ollas con visera, forma Cartagena 3, que se fabrican durante todo el siglo vi desapareciendo al final del mismo. Las ollas de borde entrante, forma Cartagena 4, suelen presentar mejores acabados en las superficies y están presentes sobre todo en los niveles de la primera mitad del siglo vi. Las cazuelas o fuentes de cocina con poca altura, junto a las ollas, son las formas de cocina más representativas del grupo con ligeras variantes que se desarrollan a lo largo de todo el siglo vi. A inicios del siglo vir localizamos cazuelas de paredes altas y exvasadas con acabados muy toscos cuyos paralelos se hallan en yacimientos de los siglos vi y viIr. Éstas últimas se documentan en Fontcalent, La Alcudia y La Arneva en contextos datados entre el 557 y el siglo viII (Gutiérrez, 1988a, 244).

Este tipo de cerámicas con las mismas formas, tratamientos toscos e incluso modeladas a mano, son frecuentes en otros puntos de la propia Cartagena 
(Cerro de Molinete, Plaza de los Tres Reyes, C/ Palas, Jara, Soledad, etc.) así como, con distintas arcillas, en otros yacimientos tardorromanos de Murcia como los de Torralba (Lorca), (Martínez y Matilla, 1988, 520), Begastri (Amante, 1984), Cerro de la Almagra (Mula) (Matilla y Pelegrín, 1985, 283), Castillo de los Garres (Murcia) (Matilla, 1988, 389), y de Alicante, tales como Benalúa, Monastil, La Alcudia, La Anerva, etc. (Reynolds, 1985, 1993; Gutiérrez, 1988). En Valencia aparecen en los estratos de relleno que cubren las estructuras de época tardorromana (Blasco et alii, 1994, 370, lám. 9). Al mismo tiempo, estas producciones toscas son también habituales en los contextos tardíos del Mediterráneo Central, como por ejemplo en Albintimilium (Olcese, 1993, 203), Classe (Fiumi y Prati, 1983, 118), Carthago (Fulford y Peacock, 1984, 155 ss.), etc.

Es muy significativa la coexistencia de ánforas de procedencia oriental y africana durante todas las fases establecidas. Sin embargo, si durante el siglo $\mathrm{v}$, el impacto de los envases orientales es mayor, tal como se ha observado en Marsella, Roma e incluso Carthago (Bonifay, 1986, 297), desde mediados del siglo vi se invierte la situación y las ánforas africanas representan el mayor porcentaje, mientras que en los niveles de principios del siglo vII, son los únicos representados. En este sentido, desde mediados del siglo vi se observa una fuerte reducción tipológica de los envases anfóricos importados que se reducen a las formas Keay LXI-LXII y XXXII, para los de procedencia africana, y Keay LIII para los de procedencia oriental, a los que únicamente habría que añadir unos envases de producción, de momento, indeterminada, que muestran, en cualquier caso, un aire de familia con las ánforas Keay LIII ( $n^{\circ}$ 255). Esta misma situación se observa en la excavaciones de la Bourse de Marsella donde en el Período 2B, fase 3, de fines del siglo vi o inicios del siglo vII, las ánforas africanas representan del 47 al $61 \%$ frente a un $22-25 \%$ de las orientales, mientras que para el siglo vII (Período 3) los escasos ejemplares orientales son considerados como residuales (Bonifay, 1986, 297).

Este predominio se observa con mucha más claridad si añadimos a los envases anfóricos las producciones finas de mesa y las cerámicas norteafricanas de cocina. La relación entre el África bizantina y la ciudad de Carthago Nova, se incrementa en estas fases considerablemente. En su mayor parte se trata de los grandes contenedores de aceite africano, Keay LXI y LXII, que inundan los principales puertos del Mediterráneo Occidental sobre todo en el siglo vi (Clay, 1990, 351). Sin embargo, es constante durante todo este amplio período la llegada de importaciones orientales distinguidas fundamentalmente en la forma Keay LIII, quizás destinada al transporte de aceite producido en la región de Antioquía o norte de Siria, que en los niveles tardíos del teatro aparece representado con desigual intensidad, en todas sus fases. Se registra su introducción en la primera mitad avanzada del siglo v (fase 8.2), siendo especialmente abundante en los niveles de la segunda mitad del siglo vi y principios del viI (fases 10.5 a 10.2). En este amplio marco cronológico se observa un aumento paulatino de los diámetros de la boca de este ánfora que coincide con los estudios realizados por Bonifay $(1986,279)$ en la Bourse de Marsella, siguiendo la hipótesis de Pensabene $(1985,191)$. Así, mientras que en la segunda mitad del siglo $\mathrm{v}$ los diámetros oscilan entre $80-82 \mathrm{~mm}$, éste se irá incrementando hasta alcanzar una media de $110 \mathrm{~mm}$. en la segunda mitad del siglo vi, llegando a los 120-122 mm. a comienzos del siglo vIr; junto a éstas últimas, y en el nivel de amortización y abandono, se documentan también ánforas de esta misma forma pero con un diámetro menor (84 y $90 \mathrm{~mm}$.) que pueden ser consideradas como residuales.

A ello hay que añadir la llegada de vino procedente de Gaza en los envases Keay LIV (LRA 4) y del Mar Negro o del Egeo en el envase Keay LXV. En su conjunto, el repertorio de envases orientales es similar al hallado en Tarragona, en el vertedero de Vila-roma, fechado entre el 440-450 (TED'A, 1994, 346) donde representan un $25,5 \%$ del total de envases anfóricos, y en esta misma ciudad, en el contexto algo más tardío (475-525) del Colegio de Arquitectos junto a la forma Keay LIVbis (Aquilué, 1993, 113). Idéntico repertorio de ánforas orientales (Keay, LIIIa, LIV, LIVbis/b y LXV) fue hallado en un vertedero de la calle Palas de Cartagena asociado a africanas Hayes 80, 99, 100, 104A y 104C (Roldán et alii, 1991, 310-311), que se debe fechar, por la presencia de esta última forma en la segunda mitad del siglo vI.

Es interesante, por otra parte, constatar la ausencia en estos niveles de ánforas béticas de aceite de la forma Keay XIII (Dressel 23) y de los envases de salazón de las regiones bético-lusitanas Keay XXIII y XVI, característicos de los siglos III a inicios del v y bien representados en los dragados del vecino Puerto de Mazarrón (Pérez Bonet, 1988, 497). Esta ausencia, parece confirmar la cronología propuesta para los niveles de Cartagena, a la vez que refuerza una cronología de la segunda mitad del siglo IV y primera mitad del $\mathrm{v}$ para el momento de apogeo del enclave mazarronero, datación que se confirma también por la ausencia de las formas más 
tardías de la Africana D y algunos contenedores muy característicos de la segunda mitad del siglo $\mathrm{v}$ y del siglo vi como los orientales Keay LIII y LIV bien documentados en Carthago Nova y su entorno.

$\mathrm{Al}$ mismo tiempo, la importación a partir del siglo vi de salsas de pescado procedente del norte de África en los envases tipo spatheion induciría a pensar en una paralización definitiva de las famosas fábricas de garum situadas, según los textos grecolatinos, en los alrededores de Carthago Nova. Precisamente, desde mediados del siglo IV estas factorías del litoral conocen un momento de gran apogeo que se prolonga probablemente durante la primera mitad, al menos, del siglo v (Ramallo, 1984a). De momento, no conocemos lo que sucede después, ya que las factorías de Mazarrón y Águilas no han proporcionado, que sepamos, un horizonte cerámico específico del siglo vi y comienzos del vII, y las posibles instalaciones de salazón de Santa Lucía y Escombreras, las más próximas a la ciudad, no han sido sometidas a una investigación sistemática.

Llama la atención, por otra parte, la abundancia de contenedores de aceite africano durante los siglos $\mathrm{v}$ al vir, lo que contrasta con la escasa representación de las ánforas béticas de aceite Dressel 20 y 23 en los niveles y pecios de los siglos I-III. En este caso, habría que pensar en un abastecimiento de la ciudad durante época alto-imperial desde el interior del territorio, lo que justificaría las numerosas prensas de aceite y torcularia halladas en distintas villae del ager Carthaginiensis que harían innecesario un aprovisionamiento del aceite bético. Por contra, las importaciones a partir sobre todo del siglo v inducirían a pensar en la falta de excedentes en esta producción local o, incluso, en la paralización de esta actividad, en muchos puntos del territorio, lo que en parte encontraría confirmación en el testimonio arqueológico de Villaricos, una de las villae bajo imperiales más extensas del ager, donde se observa una inutilización parcial de sus almazaras en un momento impreciso del siglo v (Lechuga y Amante, 1991, 378). Un fenómeno en parte similar se ha observado en el área catalana donde, a partir del siglo IV y hasta mediados del siglo vi se produce en las ciudades costeras una importación masiva de ánforas de aceite y vino, fenómeno que ha sido vinculado con una falta de suministro por parte de las $v i$ llae que en estos momentos carecen de excedentes para una comercialización extralocal (Keay, 1987, 388).

En ambos casos, salsas de pescado y aceite, las causas de esta crisis productiva local que parece traducirse de los datos hasta ahora disponibles no las podemos precisar, pero sin duda no deben ser atri- buidas a posibles efectos desoladores de las incursiones de vándalos o suevos, cuyo impacto en este territorio no debió ser muy demoledor ni duradero. En cualquier caso, es necesario ahondar en las relaciones entre la ciudad y el territorio y contrastar sus contextos materiales antes de emitir conclusiones definitivas sobre este complejo problema del aprovisionamiento urbano.

Pasando a otro aspecto, estos niveles del siglo vI representan también desde el punto de vista ceramológico la desaparición prácticamente total de las producciones hispánicas del interior peninsular, especialmente la denominada TSHT, documentada en la ciudad de forma esporádica durante el siglo $\mathrm{V}$ (Méndez y Ramallo, 1985) y la cerámica estampada gris o anaranjada, procedente en su mayor parte del sur de la Galia que en contextos tarraconenses del siglo $v$ tiene una amplia representación (vid. por ejemplo en el vertedero de Vila-roma donde representa más de un $25 \%$ del total de las cerámicas de mesa: TED'A, 1994, 342). Por otra parte, sorprende también la escasa representación de Late Roman C entre las producciones de mesa documentadas en el teatro que contrasta con la abundancia de ánforas orientales. Parece claro en este caso, a diferencia de lo que sucede con la comercialización de los contenedores de aciete africano asociados en los mismos cargamentos a las cerámicas finas de mesa, que envases ánfóricos y cerámicas orientales de mesa siguen diferentes rutas de distribución y que la terra sigillata africana D monopoliza prácticamente el mercado durante el siglo vi.

Por contra, la importación de las producciones africanas de cocina se mantiene hasta inicios del siglo vII aunque en las últimas fases su presencia es muy reducida, lo que contrasta con el incremento de las ánforas y las producciones finas de mesa. Estas producciones, caracterizadas por una arcilla depurada de color anaranjado y aspecto hojaldrado, presentan distintas técnicas de acabado. Así, con pátina cenicienta hemos individualizado ollas, cazuelas, platos tapadera de borde negrito, y morteros con visera. Su principal área de producción se sitúa en Túnez septentrional y particularmente en la región de Carthago (Aquilué, 1989c). En el primer grupo podemos incluir dos fragmentos de cazuela Hayes 197, Ostia III, fig. 267, forma atestiguada en Ostia y Carthago entre la primera mitad del siglo II y finales del siglo Iv. Su aparición en las fases 9.1 y 10.2 de nuestra excavación puede ser considerada como residual. Por el contrario, la cazuela $\mathrm{n}^{\circ}$ 66, forma Atlante I.CVII, 5-7, puede ser datada en la primera mitad del siglo vi, en correspondencia con el material de la fase 9.2 con que apareció asociada. La cazuela 
$\mathrm{n}^{\circ} 258$, forma Atlante CVIII, 4 ofrece la cronología más tardía para las importaciones de cocina africana a las costas peninsulares. Está atestiguada en Carthago en un estrato datado a inicios del siglo vi (Atlante I, 221) y en estratos del siglo viI (Fulford y Peacock, 1994, 61), fecha que coincide con la de nuestro ejemplar hallado en el nivel de abandono (fase 10.1) depositado tras la destrucción del que hemos denominado barrio bizantino, producida en torno al 620.

Junto a las cazuelas, también se ha constatado la llegada de platos-tapadera de borde ennegrecido, asimilables al Grupo 2 de Fulford $(1984,197)$. Estas tapaderas son características de los siglos II y III, aunque en Carthago se verifican aún en niveles datados entre el 475-500. Nuestro ejemplar procede de los estratos de nivelación del edificio comercial realizados en la primera mitad del siglo v. En este mismo contexto, destaca un fragmento de olla de pátina cenicienta perteneciente a la forma Vila-roma 5.40, datado en la primera mitad del siglo v y también frecuente en contextos contemporáneos de Carthago.

Asimismo, hemos considerado dentro de este grupo de importaciones africanas los morteros con visera que presentan una gran similitud de pastas con las producciones anteriormente reseñadas y una pátina generalmente blanquecina o grisácea alrededor de la visera. Formalmente, nuestros ejemplares pertenecen a los Grupos 2 y 3 de Fulford (1984, 199-200). El primero, caracterizado por una visera más larga y quebrada que la del Grupo 3, se fecha entre el 500 y el 600, aunque con un momento de esplendor hacia el 525, datación, primera mitad del siglo vi, que coincide con la de nuestros ejemplares hallados en las fases 8.1, 9.2 y 9.1. El Grupo 3, caracterizado por una visera pequeña y quebrada es frecuente entre el 600-625, datación muy similar a la que ofrece nuestro ejemplar $n^{\circ} 247$, hallado en el nivel de destrucción de la habitación 5 (fase 10.2). Aunque no muy abundante, este grupo de morteros, que suelen presentar en su fondo interno pequeñas piedrecillas negras de origen volcánico, es la forma de cocina africana más abundante y significativa de los contextos estudiados.

Entre las cerámicas de mesa importadas destacan también algunos ejemplares de producción ibicenca que podrían apuntar hacia la isla ebusitana como etapa intermedia en la ruta de navegación de las embarcaciones procedentes del norte de Africa e incluso de Oriente hacia las costas peninsulares.

Todo este material confirma esa vitalidad urbana y urbanística que comentábamos al principio y que se refleja además, ya hacia mediados del siglo $\mathrm{v}$, en la construcción de un impresionante complejo comercial, que, arquitectónicamente, recuerda en muchos aspectos los Mercados de Trajano en Roma, y el Foro de las Corporaciones en Ostia, situado junto a las instalaciones portuarias, que reemplaza y amortiza de forma definitiva uno de los edificios de mayor contenido simbólico e ideológico en la ciudad del siglo i d.C., el teatro, a la vez que demuestra una clara transformación en las estructuras del poder municipal que rige los destinos de la ciudad, muy probablemente controlado por una importante clase mercantil. Hasta su destrucción de manos visigodas, Carthago Spartaria constituyó una puerta, quizás la última, de entrada y salida de los productos, manufacturas e ideas procedentes del Mediterráneo Oriental, así como una potencial cabeza de puente en cualquier intento de reconquista por mar del territorio peninsular, de ahí su importancia y de ahí el interés en su destrucción por parte del reino de Toledo. En este mismo sentido, hay que considerar a Cartagena, además de como la principal base de provisión de los ejércitos imperiales en occidente, como ya antes lo había sido para las tropas bárquidas y durante época republicana para Roma, desde una perspectiva más amplia que trasciende los límites de su propio territorio, lo que justifica la abundancia, variedad, e incluso calidad, de un material cerámico excesivo para el consumo exclusivo de sus habitantes.

\section{ANEXO: Inventario de materiales}

La dimensiones de los distintos fragmentos, expresadas al final de la descripción, se ofrecen en milímetros (mm.). Las abreviaturas corresponden a: Db: Diámetro del borde; Dp: Diámetro del pie; $\mathrm{H}$ : Altura.

\section{FASE 8.2 (fig. 3)}

1.-CP-4346-127-1: Fondo de T. S. Africana Clara D, Hayes 61, pasta y engobe D2. Dp.: $90 \mathrm{~mm}$. 2.-CP-4346-127-2: Borde de T. S. Africana Clara D, Hayes $91 \mathrm{~A}$, pasta y engobe D2.

3.-CP-4346-127-3: Borde de T. S. Africana Clara D, Lamboglia 9 A-Hayes 63, pasta y engobe D2.

4.-CP-4346-127-5: Fondo de T. S. Africana Clara D, pasta y engobe D2. En el fondo interno decoración impresa: ramo de palma. Estilo A(ii).

5.-CP-4346-176-1: Borde de una jarra de producción ibicenca. Pasta anaranjada bien depurada, desgrasantes blancos pequeños, superficies anaran- 


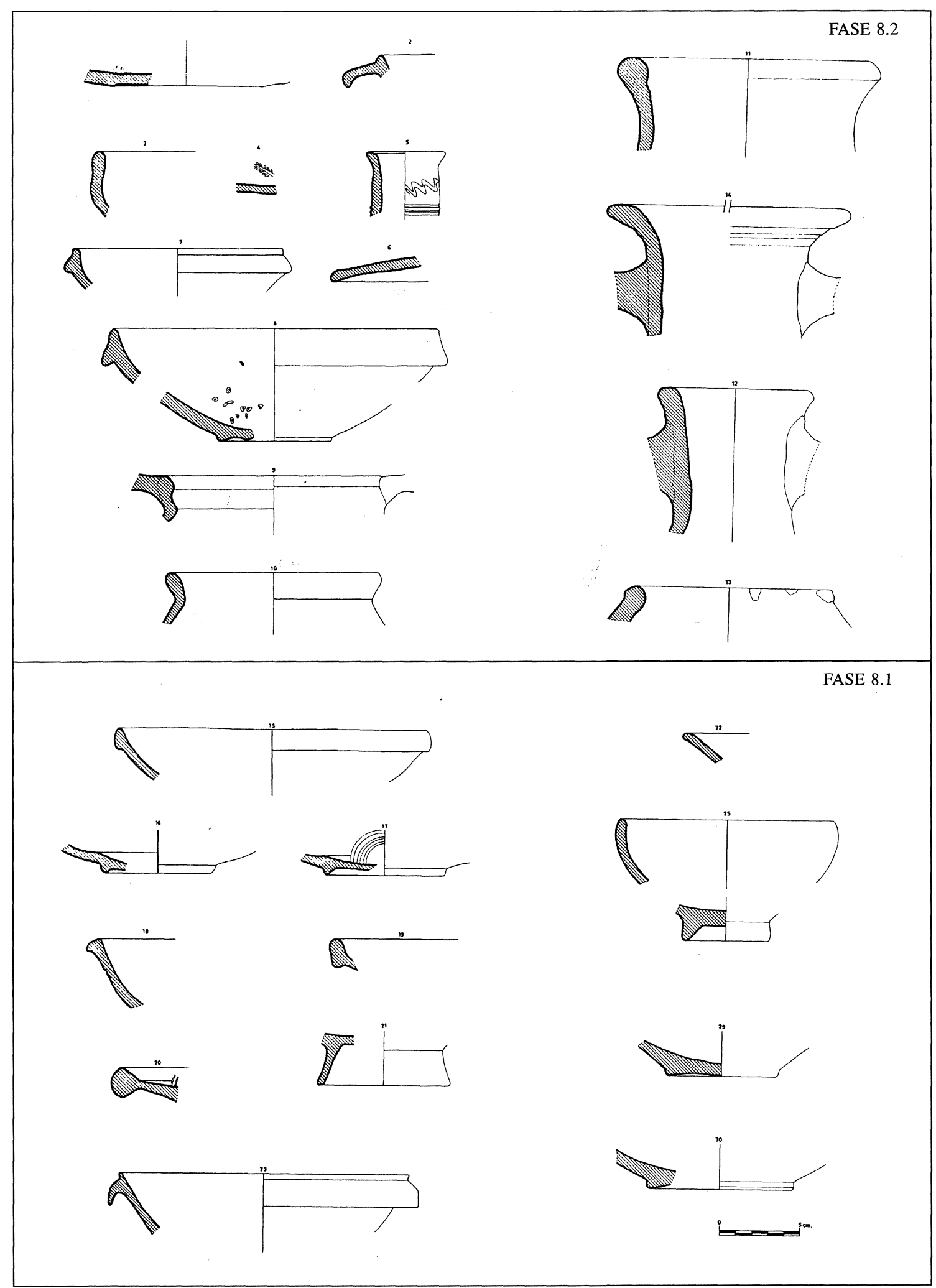

Figura 3 
jadas. Decoración ondulada a peine y anillos acanalados en el cuello. Db.: $46 \mathrm{~mm}$.

6.-CP-4346-179-4: Borde de una tapadera de cocina africana de borde negrito. Pasta gris oscura con puntos blancos y mica laminada. Superficie marrón anaranjado, borde ennegrecido. Hayes 196.

7.-CP-4346-177-3: Borde de un mortero en cerámica común. Pasta de color ocre amarillento, porosa, con vacuolas, levemente micácea, superficies alisadas ocre amarillento. Db.: $130 \mathrm{~mm}$.

8.-CP-4346-177-1 y 3: Borde y fondo de un mortero en cerámica común. Pasta marrón anaranjada, bien depurada, compacta, levemente micácea y con puntos blancos. Superficies bien torneadas y alisadas. En el fondo interno incrustaciones de piedrecillas abrasivas. Quizás de producción africana. Db.: 200 mm., Dp.: $70 \mathrm{~mm}$.

9.-CP-4346-171-1: Borde de una olla de cocina africana de pátina cenicienta. Pasta rojiza, muy compacta, desgrasantes finos de color blanco, superficie exterior con pátina cenicienta, interior anaranjada. Vila-roma 5.40. Db.: $134 \mathrm{~mm}$.

10.-CP-4346-184-3: Borde de una olla de cocina tosca de producción local. Pasta rojiza. Superficie interior rojiza y exterior ennegrecida. Forma Cartagena 2. Db.: $130 \mathrm{~mm}$.

11.-CP-4346-157-8: Borde de ánfora africana Keay XXXVIB. Pasta dura de color rojizo con partículas de cal y micas plateadas casi imperceptibles. Superficie externa de color rojizo. Db.: $142 \mathrm{~mm}$.

12.-CP-4346-159-12: Borde y arranque de asa de ánfora oriental Keay LIIIA, con restos de un trazo perteneciente a un titulus pictus. Pasta granulosa de color anaranjado con numerosas inclusiones. Superficie exterior de color anaranjado. $\mathrm{Db}: 82 \mathrm{~mm}$.

13.-CP-4346-159-10: Borde de ánfora oriental Keay LIVD. Pasta poco depurada de color marronáceo con inclusiones de micas doradas de pequeño tamaño. Superficie externa de color marrón con las típicas aplicaciones de barro en el borde. $\mathrm{Db}$ : $114 \mathrm{~mm}$.

14.-CP-4346-159-13: Borde exvasado y arranque de asa de ánfora de tipo indeterminado. Pasta porosa de color beige anaranjado con abundantes partículas de cal. Superficie externa color beige anaranjado.

\section{FASE 8.1 (figs. 3 y 4 )}

15.-CP-4379-127-4: Borde de T. S. Africana Clara D, Hayes 99 B-C, pasta y engobe D2. Db.: $190 \mathrm{~mm}$.

16.-CP-4379-127-6: Fondo de T. S. Africana Clara D, Hayes 99, pasta y engobe D2. Dp.: $64 \mathrm{~mm}$.
17.-CP-4379-127-8: Fondo de T. S. Africana Clara D, Hayes 99 B, pasta y engobe D2. Dp.: $74 \mathrm{~mm}$. 18.-CP-4379-127-10: Borde de T. S. Africana Clara D, Hayes $80 \mathrm{~B}$, pasta y engobe D1.

19.-CP-4380-127-1: Borde de T. S. Africana Clara D, Hayes 104 A, pasta y engobe D2.

20.-CP-4379-127-1: Borde de T. S. Africana Clara D, Hayes 89, pasta y engobe D1.

21.-CP-4379-127-2: Borde de T. S. Africana Clara D, Hayes 93, pasta y engobe D2. Db.: $80 \mathrm{~mm}$. 22.-CP-4380-127-2: Borde de cuenco de T.S. Africana Clara D, asimilable a la forma Hayes 81 (?). Pasta y engobe D2.

23.-CP-4380-177-1: Borde de un mortero de producción africana. Pasta anaranjada, superficies anaranjadas con pátina gris en la visera del mortero. Imitación Hayes $91 \mathrm{C}$ y similar a Fulford (1984), fig. 76.2.4. Db.: $176 \mathrm{~mm}$.

24.-CP-4379-175-1: Borde entrante de cuenco de cerámica común asimilable a la forma 21,4 de Vegas. Pasta depurada de color beige amarillento con puntos blancos esporádicos. Superficie externa beige amarillenta. Db.: $202 \mathrm{~mm}$.

25.-CP-4380-175-2: Fondo anular de plato de cerámica común de mesa. Pasta dura de color marrón grisáceo con puntos blancos y micas plateadas de pequeño tamaño. Superficie externa de color marrón grisáceo. Dp.: $52 \mathrm{~mm}$.

25bis.-CP-4380-175-2: Cuenco de borde entrante de cerámica común de mesa, Vegas 21,4. Pasta depurada de color marrón anaranjado con puntos blancos esporádicos y micas doradas en superficie. Superficie externa color beige anaranjado. Db.: 134 $\mathrm{mm}$.

26.-CP-4380-175-2: Cuenco de borde entrante de cerámica común de mesa, Vegas 21,4. Pasta depurada de color anaranjado con puntos blancos esporádicos y micas doradas en superficie. Superficie externa color beige amarillento. Db.: $150 \mathrm{~mm}$.

27.-CP-4380-176-2: Borde de jarra de cerámica común de mesa. Pasta dura de color anaranjado con puntos blancos y micas doradas pequeñas en superficie. Superficie externa color marrón grisáceo. Db.: $112 \mathrm{~mm}$.

28.-CP-4379-176-1: Borde de jarra de cerámica común. Pasta depurada de color marrón anaranjado, con puntos blancos esporádicos y micas plateadas imperceptibles. Superficie externa marrón anaranjada. Db.: $74 \mathrm{~mm}$.

29.-CP-4379-179-3: Fondo de plato de cerámica común de mesa. Pasta depurada de color rojizo anaranjado con puntos blancos y micas doradas casi imperceptibles en superficie. Superficie exterior beige y anaranjada. Dp.: $68 \mathrm{~mm}$. 


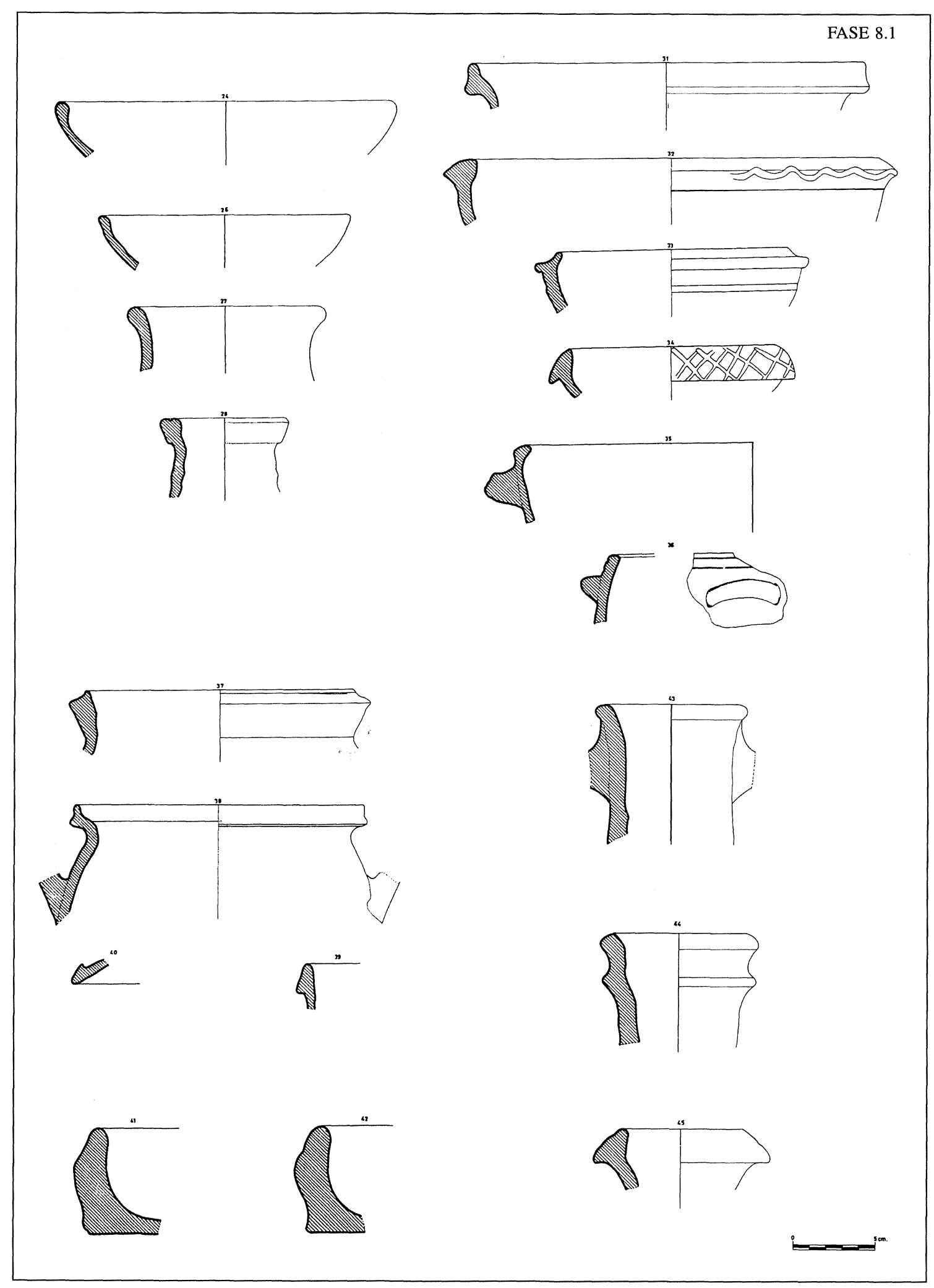

Figura 4 
30.-CP-4379-179-4: Fondo de plato de cerámica común de mesa. Pasta depurada de color anaranjado con puntos blancos y micas doradas casi imperceptibles en superficie. Superficie externa alisada y de color anaranjado. Dp.: $90 \mathrm{~mm}$.

31.-CP-4380-179-1: Borde de vasija de almacenamiento de cerámica común. Pasta dura de color rojizo anaranjado con puntos blancos y micas pequeñas en superficie. Superficie externa engobada en beige amarillento. Db.: $240 \mathrm{~mm}$.

32.-CP-4379-177-3: Borde con ondulaciones de mortero de cerámica común. Pasta depurada de color beige con puntos blancos y micas doradas en superficie. Superficie externa color beige. Db.: $248 \mathrm{~mm}$.

33.-CP-4379-177-1: Borde con visera de cuenco de cerámica común. Pasta depurada color beige amarillento, con puntos de cal y micas plateadas casi imperceptibles. Superficie exterior beige amarillento. Db.: $140 \mathrm{~mm}$.

34.-CP-4379-177-2: Borde con visera decorado con una retícula impresa de cuenco de cerámica común. Pasta depurada de color marrón claro con puntos blancos, cristales de cuarzo y micas plateadas casi imperceptibles en superficie. Superficie exterior con restos de un engobe rojizo. Db.: $126 \mathrm{~mm}$.

35.-CP-4380-184-3: Borde de un cuenco de cocina tosca de producción local, con asa aplicada con digitaciones. Pasta rojiza. Superficie interior rojiza y exterior ennegrecida. Forma Cartagena 4.1. Db.: $280 \mathrm{~mm}$.

36.-CP-4379-184-5: Fragmento de borde de una olla de cocina tosca de producción local. Pasta rojiza. Superficie interior rojiza y exterior ennegrecida. Forma Cartagena 4.1.

37.-CP-4379-184-1: Borde de una olla de cocina tosca de producción local. Pasta rojiza. Superficie interior rojiza y exterior marrón ennegrecida. Forma Cartagena 1.3. Db.: $166 \mathrm{~mm}$.

38.-CP-4379-184-3: Borde de una olla de cocina tosca de producción local. Pasta rojiza. Superficie interior rojiza y exterior ennegrecida. Forma Cartagena 3.1. Db.: $180 \mathrm{~mm}$.

39.-CP-4380-184-1: Borde de una olla de cocina tosca de producción local. Pasta rojiza. Superficie interior rojiza y exterior ennegrecida. Forma Cartagena 4. Db.: $280 \mathrm{~mm}$.

40.-CP-4379-184-4: Borde de una tapadera de cocina africana. Pasta marrón-anaranjada con puntos blancos y mica laminada plateada. Borde y superficie exterior ennegrecida. Asimilable a Reynolds (1985), Grupo 1 y a Fulford (1984), fig. 56.5.

41.-CP-4380-184-4: Perfil completo de una cazuela de cocina tosca de producción local. Pasta ro- jiza. Superficie interior rojiza y exterior ennegrecida. Forma Cartagena 11. Db./ Dp: indeterminable. H.: $66 \mathrm{~mm}$.

42.-CP-4379-184-6: Perfil completo de una cazuela de cocina tosca de producción local. Pasta rojiza. Superficie interior rojiza y exterior marrón ennegrecida. Forma Cartagena 11. H.: $65 \mathrm{~mm}$.

43.-CP-4379-159-3: Borde y arranque superior de asa de ánfora Keay LIII. Pasta granulosa de color beige anaranjado, con numerosas inclusiones. Superficie exterior beige anaranjado. Db.: $80 \mathrm{~mm}$.

44.-CP-4379-159-4: Borde de ánfora Keay LIII. Pasta granulosa de color beige anaranjado, con numerosas inclusiones. Superficie exterior beige amarillento. Db.: $80 \mathrm{~mm}$.

45.-CP-4380-157-1: Borde de ánfora africana Keay XLI. Pasta granulosa de color anaranjado con abundantes inclusiones de cal, cuarzo y partículas negras y marrones indeterminadas. Superficie externa color anaranjado. Db: $70 \mathrm{~mm}$.

\section{FASE 9.2 (figs. 5 y 6 )}

46.-CP-4372-127-20: Borde de T. S. Africana Clara D, Hayes 104 C, pasta y engobe D1. Db.: 294 $\mathrm{mm}$.

47.-CP-4371-127-3: Borde de T. S. Africana Clara D, Hayes $104 \mathrm{C}$, pasta y engobe D2.

48.-CP-4372-127-6: Borde de T. S. Africana Clara D, Hayes $99 \mathrm{C}$, pasta y engobe D2. Db: $160 \mathrm{~mm}$.

49.-CP-4371-127-2: Borde de T. S. Africana Clara D, Hayes $99 \mathrm{C}$, pasta y engobe D2. Db. $190 \mathrm{~mm}$.

50.-CP-4372-127-1: Borde de T. S. Africana Clara D, Hayes 99 A-B, pasta y engobe D2.

51.-CP-4371-127-1: Fondo de T. S. Africana Clara D, Hayes 99, pasta y engobe D2. Dp.: $80 \mathrm{~mm}$. 52.-CP-4372-127-14: Borde de T. S. Africana Clara D, Hayes $91 \mathrm{C}$, pasta y engobe D2. Db.: $140 \mathrm{~mm}$.

53.-CP-4372-127-15: Borde de T. S. Africana Clara D, Hayes $91 \mathrm{C}$, pasta y engobe D2. Db.: $140 \mathrm{~mm}$.

54.-CP-4371-127-5: Fondo de T. S. Africana Clara D, Hayes $91 \mathrm{C}$, pasta y engobe D2. Dp.: $44 \mathrm{~mm}$.

55.-CP-4372-127-25: Borde de T. S. Africana Clara D, Hayes 93 B; Waage 1948, tav. IX, pasta y engobe D2. Db.: $134 \mathrm{~mm}$.

56.-CP-4371-127-4: Borde de T. S. Africana Clara D, Hayes 93, pasta y engobe D2.

57.-CP-4372-127-17: Borde de T. S. Africana Clara D, Hayes 90 , pasta y engobe D1. 


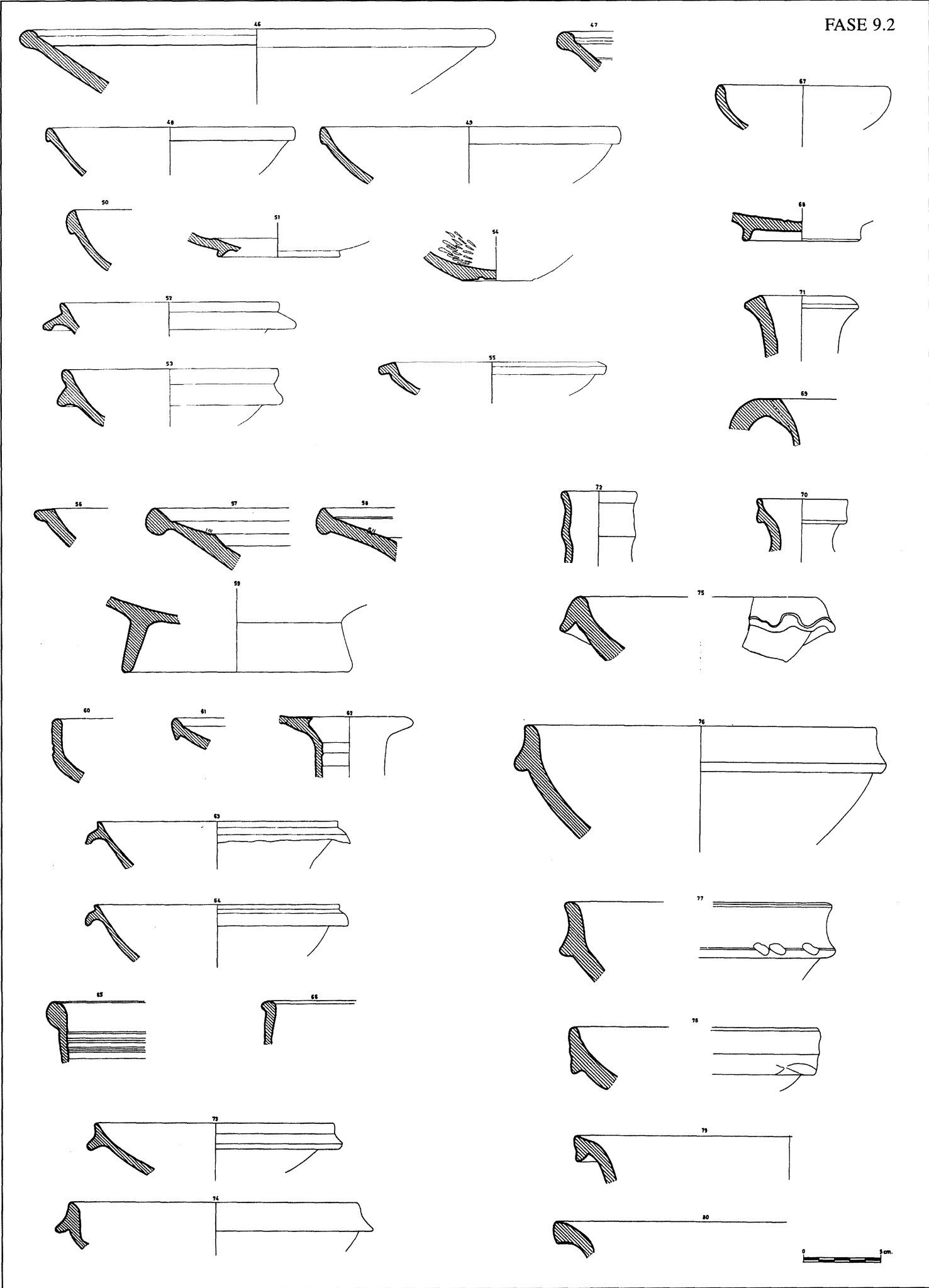

Figura 5 
58.-CP-4371-127-6: Borde de T. S. Africana Clara D, Hayes 90 , pasta y engobe D2.

59.-CP-4372-127-18: Fondo de T. S. Africana Clara D, Hayes 90 o 93, pasta y engobe D2. Dp.: $150 \mathrm{~mm}$.

60.-CP-4372-127-24: Borde de T. S. Africana Clara D, Hayes 63, pasta y engobe D2.

61.-CP-4372-127-26: Borde de T. S. Africana Clara D, Hayes 61; Lamboglia 53 bis, pasta y engobe D2.

62.-CP-4372-125-1: Borde de una botella de T. S. Africana Clara A, Boninu 1971-72, fig. 42, pasta y engobe A1. Db.: $60 \mathrm{~mm}$.

63.-CP-4371-177-1: Borde de un mortero de producción africana. Pasta anaranjada, superficies anaranjadas con pátina gris en la visera del mortero. Similar a Fulford (1984), fig. 76. 2.4. Db.: 160 $\mathrm{mm}$.

64.-CP-4372-177-1: Borde de un mortero de producción africana. Pasta anaranjada, superficies anaranjadas con pátina gris en la visera del mortero. Imitación Hayes 91 D y similar a Fulford (1984), fig. 76. 2,4. Db.: $162 \mathrm{~mm}$.

65.-CP-4372-171-1: Borde de olla de cocina africana Hayes 197. Pasta anaranjada, superficies anaranjadas y pátina cenicienta al exterior. $\mathrm{Db}$.: $270 \mathrm{~mm}$.

66.-CP-4372-171-2: Borde de cuenco de cerámica africana. Pasta granulosa color marrón anaranjado, superficies amarronadas y exterior con una ligera pátina cenicienta.

67.-CP-4372-175-1: Borde entrante de cuenco de cerámica común de mesa Vegas 21,1. Pasta depurada de color marrón anaranjado. Superficie externa color beige anaranjado. Db.: $104 \mathrm{~mm}$.

68.-CP-4372-175-2: Pie anular de un plato de cerámica común de mesa. Pasta depurada color anaranjado. Superficies anaranjadas. Dp.: $72 \mathrm{~mm}$.

69.-CP-4372-176 -3: Borde y arranque de asa de jarrita monoansada de cerámica común, similar a Vegas 43. Pasta dura de color marrón grisáceo con puntos blancos esporádicos, esquistos grisáceos laminados y micas plateadas de tamaño muy pequeño. Superficie externa color grisáceo con signos evidentes de haber estado expuesta al fuego. Db.: $72 \mathrm{~mm}$.

70.-CP-4372-176-4: Borde moldurado de una botella de cerámica común, similar a Vegas 38. Pasta depurada de color rojizo. Superficie exterior color rosado-rojizo. Db.: $54 \mathrm{~mm}$.

71.-CP-4372-176-9: Borde de jarra de cerámica común. Pasta dura de color marrón rojizo con puntos blancos que producen poros y micas plateadas de tamaño pequeño sobre todo en superficie. Superficie externa color beige. Db.: $52 \mathrm{~mm}$.
72.-CP-4372-176-5: Borde y arranque de asa de una botellita de cerámica común. Pasta depurada de color marrón anaranjado con pequeños puntos blancos. Superficie exterior engobada en beige amarillento. Db.: $42 \mathrm{~mm}$.

73.-CP-4372-177-2: Borde de un mortero de producción africana. Pasta anaranjada, superficies anaranjadas con pátina gris en la visera del mortero. Similar a Fulford (1984), fig. 77. 10,1. Db.: $162 \mathrm{~mm}$.

74.-CP-4372-177-6: Borde con visera de mortero de cerámica común. Pasta depurada de color rosado-rojizo con puntos blancos que provocan vacuolas y micas plateadas casi imperceptibles. Superficie exterior color rosado-rojizo. Db.: $196 \mathrm{~mm}$.

75.-CP-4372-177-7: Borde con visera con ondulaciones en la parte inferior, de un mortero de cerámica común. Pasta depurada de color marrón claro, con pequeños puntos blancos, partículas marrones y rojizas indeterminadas y micas plateadas de tamaño muy pequeño. Superficie externa color beige anaranjado.

76.-CP-4372-177-3: Borde con visera de mortero de cerámica común. Pasta depurada de color rojizo, con partículas blancas que producen vacuolas, esquistos grises laminados esporádicos y micas plateadas en superficie. Superficie externa color rosado rojizo. Db.: $220 \mathrm{~mm}$.

77.-CP-4372-177-8: Borde de mortero de cerámica común con decoración impresa en la parte inferior del mismo. Pasta depurada de color beige, con pequeños puntos blancos y micas plateadas en superficie. Superficie exterior color beige.

78.-CP-4372-177-4: Borde con decoración impresa en la parte inferior, de un mortero de cerámica común. Pasta depurada de color beige, con pequeños puntos blancos y micas plateadas en superficie. Superficie exterior color beige.

79.-CP-4372-177-5: Borde de vasija de almacenaje Vegas 12 de cerámica común. Pasta dura de color anaranjado con partículas blancas que producen vacuolas, esquistos grises laminados esporádicos y micas plateadas en superficie. Superficie externa de color beige. Db.: $272 \mathrm{~mm}$.

80.-CP-4371-177-4: Borde de un vaso de almacenaje, borde exvasado y engrosado al exterior. Pasta anaranjada, depurada con mica fina. Superficie exterior con engobe beige amarillento. Db.: $300 \mathrm{~mm}$.

81.-CP-4372-184-43: Borde de una olla de cocina tosca de producción local. Pasta rojiza. Superficie interior rojiza y exterior ennegrecida. Forma Cartagena 1.2. Db.: $168 \mathrm{~mm}$.

82.-CP-4371-184-1: Borde de una olla de coci- 


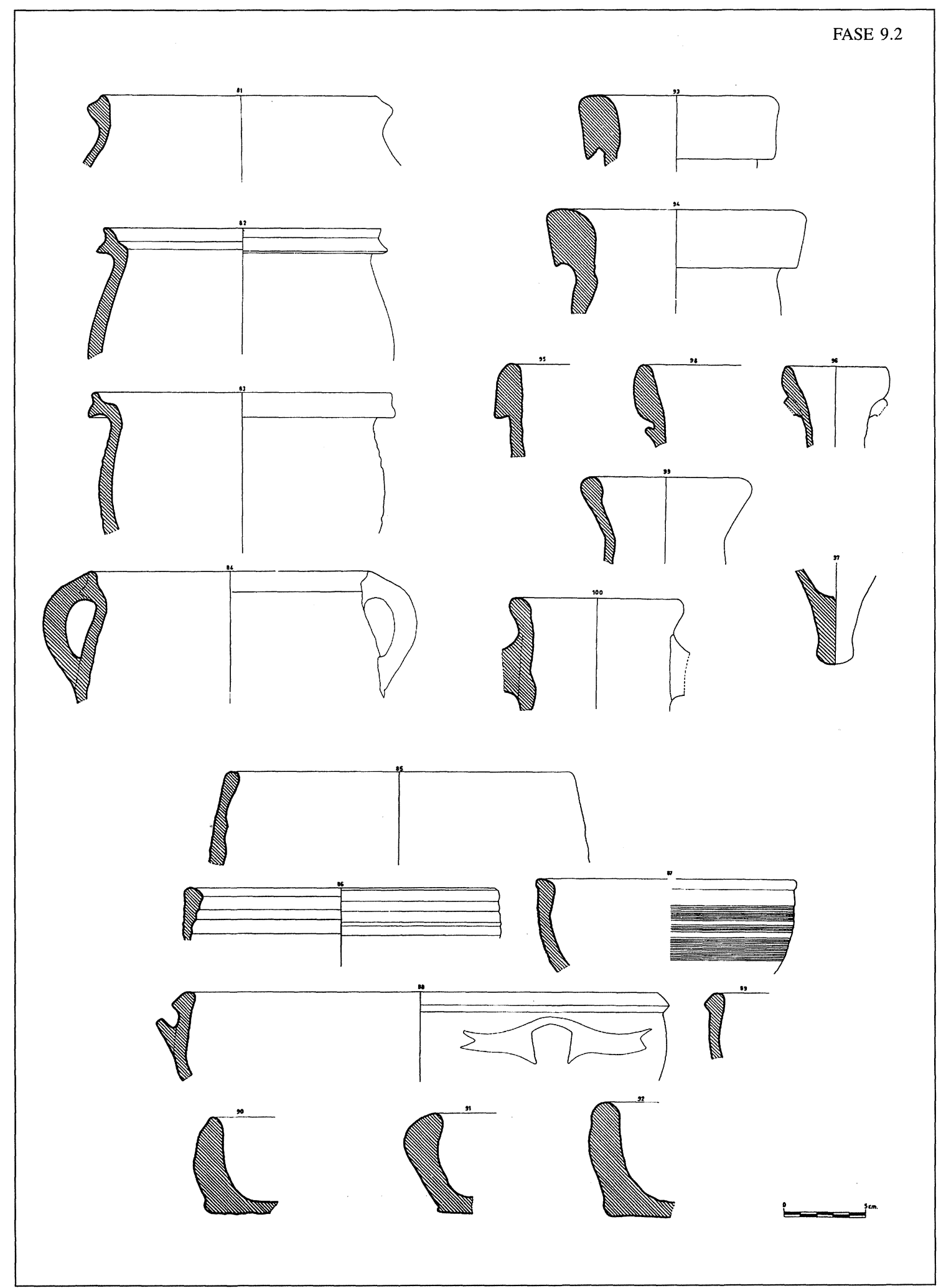

Figura 6 
na tosca de producción local. Pasta rojiza. Superficie interior rojiza y exterior ennegrecida. Forma Cartagena 3.1. Db.: $170 \mathrm{~mm}$.

83.-CP-4372-184-12: Borde de una olla de cocina tosca de producción local. Pasta rojiza. Superficie interior rojiza y exterior ennegrecida. Forma Cartagena 3.1. Db.: $180 \mathrm{~mm}$.

84.-CP-4372-184-17: Borde de una olla de cocina tosca de producción local. Pasta rojiza. Superficie interior rojiza y exterior ennegrecida. Forma Cartagena 3.1. Db.: $170 \mathrm{~mm}$.

85.-CP-4372-184-6: Borde de una olla de cocina tosca de producción local. Pasta rojiza. Superficie interior rojiza y exterior ennegrecida. Forma Cartagena 4.1. Db.: $202 \mathrm{~mm}$.

86.-CP-4372-184-4: Borde de una olla de cocina tosca de producción local. Pasta rojiza. Superficie interior rojiza, exterior engobada en beige y ennegrecida. Forma Cartagena 4. Db.: $184 \mathrm{~mm}$.

87.-CP-4372-184-8: Borde de cuenco de cerámica tosca. Pasta marrón anaranjado. Superficie interior beige anaranjada y exterior ennegrecida. Decoración exterior con grandes bandas incisas a peine.

88.-CP-4371-184-3: Borde de un cuenco de cocina tosca de producción local. Asa aplicada con digitaciones. Pasta rojo anaranjado. Superficie interior anaranjada y exterior ennegrecida. Forma Cartagena 5. Db.: $290 \mathrm{~mm}$.

89.-CP-4372-184-7: Borde de un cuenco de cocina tosca de producción local. Pasta marrón anaranjado. Superficie interior marrón anaranjada, exterior ennegrecida. Forma Cartagena 5.

90.-CP-4372-184-53: Perfil completo de una cazuela de cocina tosca de producción local. Pasta rojiza. Superficie interior rojiza y exterior ennegrecida. Forma Cartagena 11. H.: $59 \mathrm{~mm}$.

91.-CP-4372-184-52: Fragmento con perfil completo de una cazuela de cocina tosca de producción local. Pasta rojiza. Superficie interior rojiza y exterior ennegrecida. Forma Cartagena 10. Db.: 378 mm., Dp.: 380 mm., H.: $61 \mathrm{~mm}$.

92.-CP-4372-184-46: Fragmento con perfil completo de una cazuela de cocina tosca de producción local. Pasta rojiza. Superficie interior rojiza y exterior ennegrecida. Forma Cartagena 12.1. H.: $70 \mathrm{~mm}$.

93.-CP-4372-157-4: Fragmento de borde de ánfora africana Keay LXIIE. Pasta dura de color rojizo con partículas de cal (algunas muy gruesas) y cristales de cuarzo esporádicos. Superficie exterior engobada en beige amarillento. Db.: $100 \mathrm{~mm}$.

94.-CP-4372-157-2: Fragmento de borde de ánfora africana Keay LXIIA. Pasta dura de color anaranjado con partículas de cal que producen gran- des vacuolas y micas plateadas casi imperceptibles. Superficie exterior engobada en beige amarillento. Db.: $14 \mathrm{~mm}$.

95.-CP-4372-157-3: Fragmento de borde de ánfora de tipo indeterminado. Pasta de color gris amarronado con partículas de cal, micas plateadas imperceptibles y esporádicos cristales de cuarzo de gran tamaño. Superficie exterior de color beige.

96.-CP-4371-159-2: Fragmento de borde y arranque de asa de anforilla tipo spatheion, Keay XXVIG. Pasta depurada de color marrón claro, con pequeñas partículas de cal y micas plateadas. Superficie exterior marrón clara, con signos de haber sido expuesta al fuego. Db.: $60 \mathrm{~mm}$.

97.-CP-4372-159-1: Fragmento de pivote macizo de anforilla tipo spatheion. Pasta dura de color anaranjado con partículas de cal de tamaño pequeño y micas plateadas imperceptibles. Superficie exterior espatulada y de color anaranjado.

98.-CP-4371-159-1: Fragmento de borde de ánfora de tipo indeterminado. Pasta dura, de tacto granuloso y color beige amarillento, con partículas de cal y micas plateadas. Superficie exterior beige amarillenta con poros y vacuolas. Db.: $130 \mathrm{~mm}$.

99.-CP-4372-159-7: Fragmento de borde de ánfora oriental Keay LXV. Pasta de color marrón claro con partículas de cal y micas plateadas casi imperceptibles. Superficie exterior engobada en color beige. Db.: $90 \mathrm{~mm}$.

100.-CP-4371-159-8: Fragmento de borde y arranque superior de asa del ánfora Keay LIIIA. Pasta granulosa color beige anaranjado con numerosas inclusiones. Superficie externa de color beige. Db.: $100 \mathrm{~mm}$.

\section{FASE 9 (fig. 7)}

101.-CP-4357-127-2: Borde de T. S. Africana Clara D, Hayes 99 C, pasta y engobe D2. Db.: 180 $\mathrm{mm}$.

102.-CP-4357-127-1: Borde de T. S. Africana Clara D, Hayes 99C, pasta y engobe D2.

103.-CP-4357-127-3: Borde de T. S. Africana Clara D, Hayes $99 \mathrm{C}$, pasta y engobe D2.

104.-CP-4357-127-4: Borde de T. S. Africana Clara D, Hayes $104 \mathrm{C}$, pasta y engobe D2.

105.-CP-4357-146-1: Margo y disco de una lucerna de T. S. Africana Clara D, Hayes II B. Decoración estilo $\mathrm{E}$ (ii) y $\mathrm{D}$.

106.-CP-4357-176-1: Borde de una jarra en cerámica común. Pasta anaranjada con puntos blan$\cos$ y mica. Superficie exterior con engobe ocre. Asimilable a Vila-roma 6.116. 


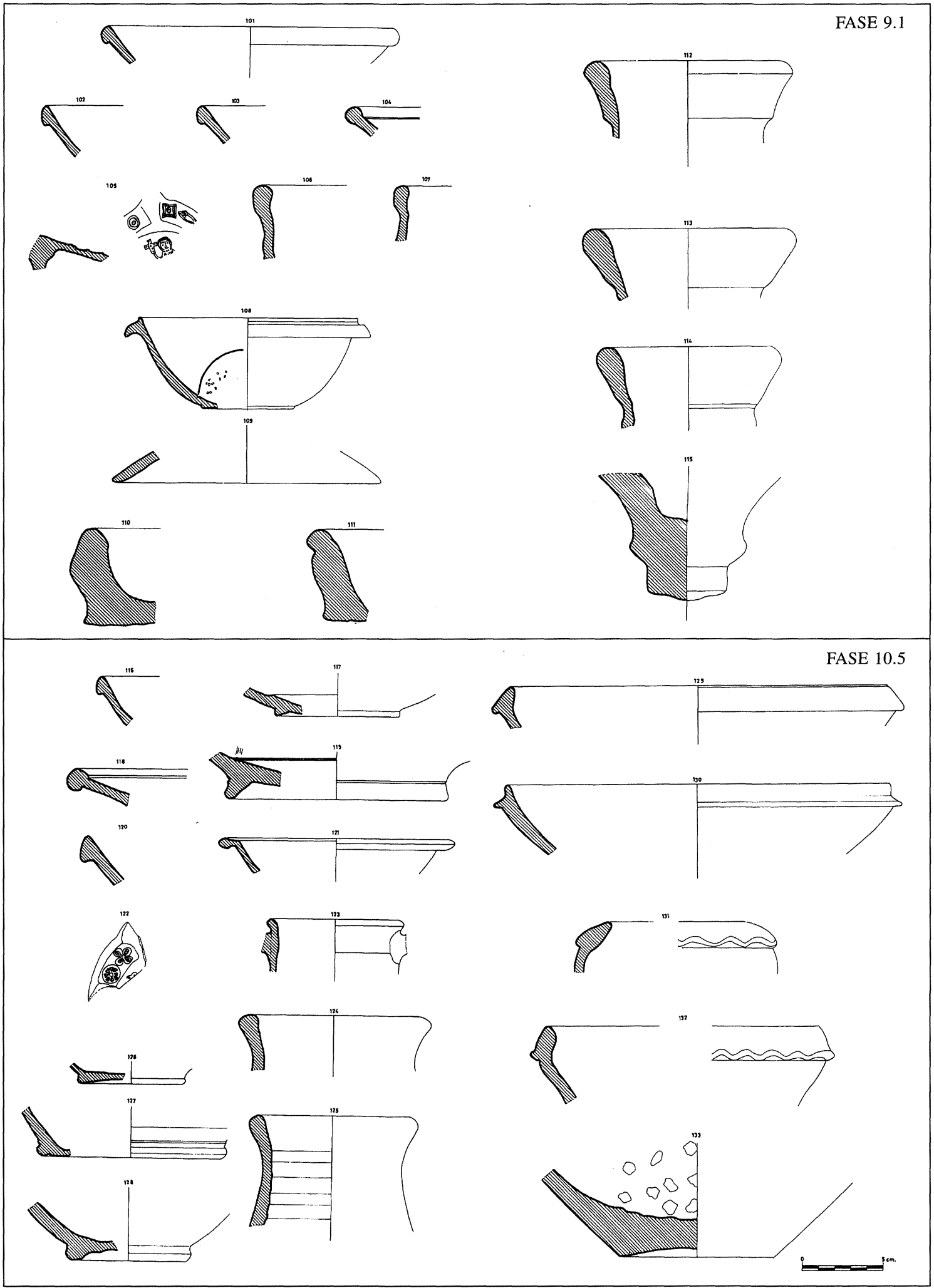

Figura 7 
107.-CP-4357-176-2: Borde de una jarra en cerámica común. Pasta anaranjada con puntos blan$\cos$ y mica. Superficie exterior con engobe beigeocre. Asimilable a Vila-roma 6.116.

108.-CP-4357-177-1: Perfil completo de un mortero de producción africana. Pasta anaranjada, superficies anaranjadas con pátina gris en la visera del mortero. Fondo interno con piedrecillas abrasivas. Similar a Fulford (1984), fig. 76. 3.1. Db.: 140 mm., Dp.: 58 mm., H.: 58 mm.

109.-CP-4357-184-8: Borde de una tapadera de cocina tosca de producción local. Pasta rojiza. Superficie interior rojiza y exterior ennegrecida. Forma Cartagena 14.2. Db.: $170 \mathrm{~mm}$.

110.-CP-4357-184-3: Perfil completo de una cazuela de cocina tosca de producción local. Pasta rojiza. Superficie interior marrón y exterior con engobe marrón ennegrecido. Forma Cartagena 12.2. H.: $62 \mathrm{~mm}$.

111.-CP-4357-184-2: Perfil completo de una cazuela de cocina tosca de producción local. Pasta rojiza. Superficie interior rojiza y exterior ennegrecido. Forma Cartagena 11. H.: $58 \mathrm{~mm}$.

112.-CP-4357-157-1: Borde de ánfora africana asimilable a Keay LXI. Pasta granulosa de color beige amarillento con partículas de cal de tamaño mediano y micas plateadas casi imperceptibles. Superficie externa beige amarillento. Db.: $104 \mathrm{~mm}$.

113.-CP-4357-159-2: Borde de ánfora Keay LXV. Pasta depurada de color beige anaranjado con esporádicas partículas de cal y micas plateadas casi imperceptibles. Superficie externa beige-anaranjado. Db.: $106 \mathrm{~mm}$.

114.-CP-4357-159-3: Borde de ánfora Keay LXV. Pasta depurada de color beige con micas plateadas casi imperceptibles. Superficie externa beige. Db.: $94 \mathrm{~mm}$.

115.-CP-4357-157-4: Pivote anular de ánfora africana Keay LXI-LXII. Pasta dura tipo sandwich, exterior en marrón y núcleo rosado. Inclusiones de partículas de cal, cristales de cuarzo y micas plateadas casi imperceptibles. Superficie externa engobada en beige amarillento.

\section{FASE 10.5 (figs. 7 y 8 )}

116.-CP-4369-127-3: Borde de T. S. Africana Clara D, Hayes 99 C, pasta y engobe D1.

117.-CP-4369-127-9: Fondo de T. S. Africana

Clara D, Hayes 99, pasta y engobe D2. Dp.: $80 \mathrm{~mm}$.

118.-CP-4369-127-1: Borde de T. S. Africana

Clara D, Hayes 105, pasta y engobe D2.

119.-CP-4369-127-8: Fondo de T. S. Africana Clara D, Hayes 105, pasta y engobe D2. Dp.: $140 \mathrm{~mm}$.
120.-CP-4369-127-2: Borde de T. S. Africana Clara D, Hayes 103, pasta y engobe D1.

121.-CP-4369-127-4: Borde de T. S. Africana Clara D, Hayes 107, pasta y engobe D2. Db: $146 \mathrm{~mm}$.

122.-CP-4369-146-1: Margo y disco de una lucerna de T. S. Africana Clara D, pasta y engobe D2. Decoración Estilo E.

123.-CP-4369-176-4: Borde de jarra de cerámica común. Pasta dura de color anaranjado con puntos blancos y micas plateadas de pequeño tamaño. Superficie externa alisada y engobada en color beige amarillento. $\mathrm{Db}$.: $82 \mathrm{~mm}$.

124.-CP-4369-176-1: Borde de jarra/ánfora de tipo indeterminado de cerámica común. Pasta dura de color anaranjado con esquistos grisáceos laminados, partículas oscuras indeterminadas y abundantes micas plateadas especialmente en superficie. Superficie exterior de color anaranjado. Db.: $108 \mathrm{~mm}$.

125.-CP-4369-176-10: Borde de jarra de cerámica común. Pasta depurada de color beige amarillento con puntos blancos de pequeño tamaño. Superficie externa color beige. $\mathrm{Db} .: 92 \mathrm{~mm}$.

126.-CP-4369-176-11: Fondo plano de jarra de cerámica común. Pasta depurada de color beige con puntos blancos de pequeño tamaño y micas doradas abundantes en superficie. Superficie externa color beige. Dp.: $70 \mathrm{~mm}$.

127.-CP-4369-176-14: Fondo de jarra de cerámica común. Pasta dura de color anaranjado y beige con puntos blancos de pequeño tamaño y micas plateadas /doradas abundantes en superficie. Superficie externa de color anaranjado. Dp.: $114 \mathrm{~mm}$.

128.-CP-4369-176-9: Base anular y galbo de jarra de cerámica común. Pasta de color anaranjado con puntos blancos abundantes y micas plateadas casi imperceptibles. Superficie externa engobada en beige-blanquecino. Dp.: $74 \mathrm{~mm}$.

129.-CP-4369-177-1: Borde de mortero de cerámica común. Pasta dura y depurada de color marrón anaranjado con puntos blancos y micas doradas sobre todo en superficie. Superficie externa color anaranjado. Db.: $234 \mathrm{~mm}$.

130.-CP-4369-177-2: Borde de mortero de cerámica común. Pasta depurada de color anaranjado con puntos blancos y micas plateadas sobre todo en superficie. Superficie externa color anaranjado. Db.: $234 \mathrm{~mm}$.

131.-CP-4369-177-3: Borde de mortero de cerámica común. Pasta depurada de color anaranjado con puntos blancos y micas plateadas sobre todo en superficie. Superficie externa color anaranjado.

132.-CP-4369-177-5: Borde de mortero de cerámica común. Pasta depurada de color beige ama- 


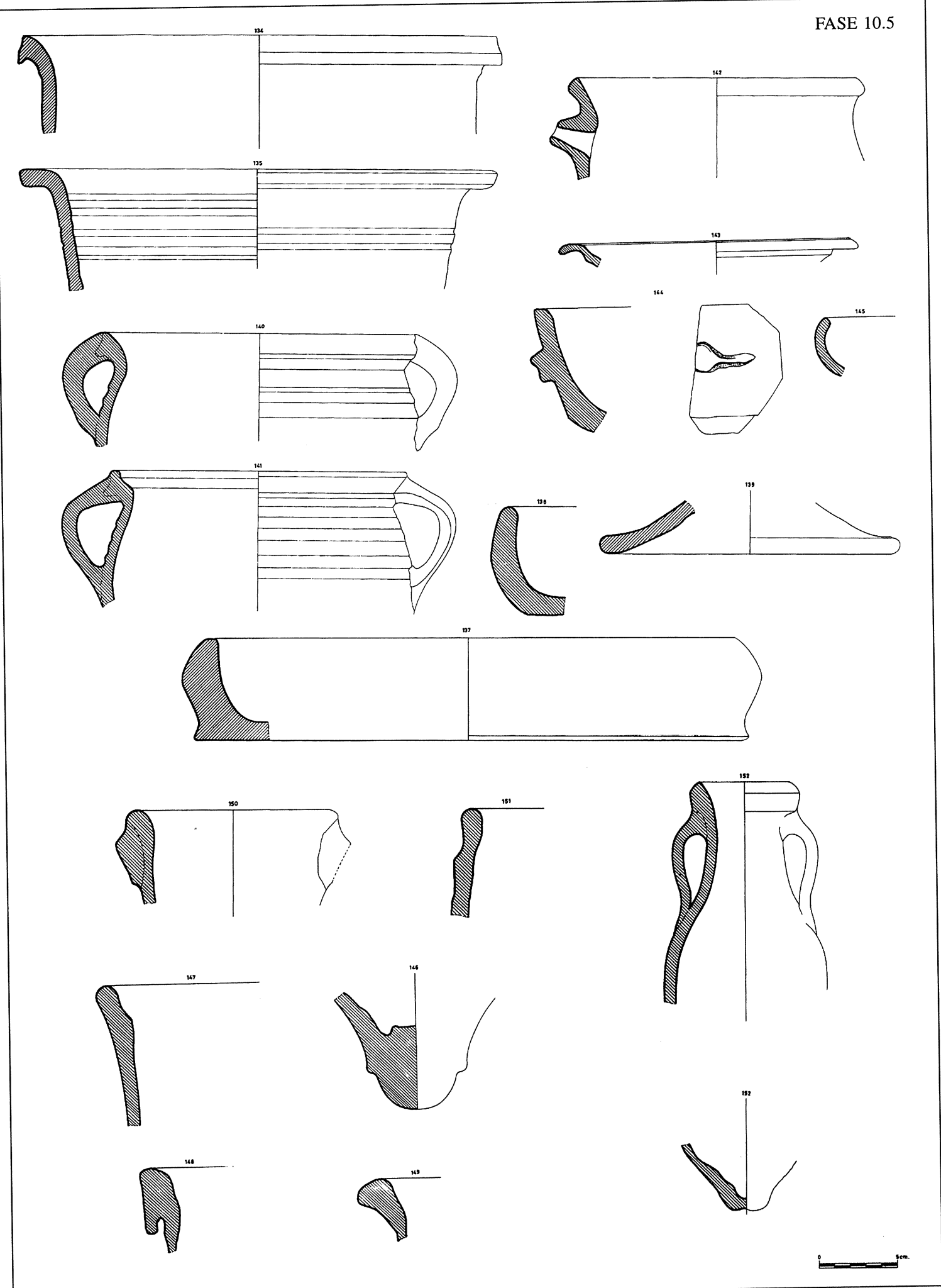

Figura 8 
rillento con puntos blancos y micas doradas. Superficie externa color beige amarillento.

133.-CP-4369-177-6: Fondo de un mortero de cerámica común. Pasta depurada de color anaranjado claro con puntos blancos, mica plateada en superficie y esquistos grises laminados esporádicos. Superficie exterior de color rosa-rojizo. En el fondo interno incrustaciones de piedrecillas abrasivas. Probablemente de producción africana. Similar a Fulford (1984), fig. 21. Db.: $94 \mathrm{~mm}$.

134.-CP-4369-179-10: Borde de una vasija de almacenaje de gran tamaño de cerámica común. Pasta de color rojizo anaranjado con puntos blancos y micas plateadas abundantes. Superficie externa con restos de engobe beige-amarillento. Db.: $306 \mathrm{~mm}$.

135.-CP-4369-179-9: Borde de una vasija de almacenaje de gran tamaño de cerámica común. Pasta de color beige anaranjado con puntos blancos y micas plateadas abundantes. Superficie externa color beige. $\mathrm{Db}$.: $308 \mathrm{~mm}$.

136.-CP-4369-179-11: Borde de cuenco de cerámica común. Pasta de color rojizo con abundantes puntos blancos, micas plateadas, y partículas oscuras esporádicas. Superficie externa de color rojizo.

137.-CP-4369-184-1: Perfil completo de una cazuela de cocina tosca de producción local. Pasta rojiza con el núcleo amarronado. Superficie interior rojiza y exterior ennegrecida. Forma Cartagena 12.2. Db.: 340 mm., Dp.: 356 mm., H.: $66 \mathrm{~mm}$.

138.-CP-4369-184-2: Perfil completo de una cazuela de cocina tosca de producción local. Pasta rojiza. Superficie interior y exterior ennegrecida. Forma Cartagena 12.1. H.: $70 \mathrm{~mm}$.

139.-CP-4369-184-19: Borde de una tapadera de cocina tosca de producción local. Pasta rojiza con el núcleo grisáceo. Superficie interior y exterior con engobe marrón. Borde ennegrecido. Forma Cartagena 14.1. Db.: $188 \mathrm{~mm}$.

140.-CP-4369-184-9: Borde de una olla de cocina tosca de producción local. Pasta rojiza. Superficie interior rojiza y exterior ennegrecida. Forma Cartagena 3.3. Db.: $204 \mathrm{~mm}$.

141.-CP-4369-184-8: Borde de una olla de cocina tosca de producción local. Pasta rojiza. Superficie interior rojiza y exterior engobe marrón claro ennegrecido. Forma Cartagena 3.1. Db.: $192 \mathrm{~mm}$.

142.-CP-4369-184-18: Borde de una olla con pitorro vertedor, de cocina tosca de producción local. Pasta rojiza. Superficie interior rojiza y exterior ennegrecida. Forma Cartagena 2.4. Db.: $186 \mathrm{~mm}$.

143.-CP-4369-171-5: Borde de un plato-tapadera de cerámica de cocina de producción africana. Pasta anaranjada con puntos blancos, borde ennegrecido. Db.: $182 \mathrm{~mm}$.
144.-CP-4369-184-22: Borde de un cuenco de cocina tosca importada. Modelada a mano o torno lento, paredes verticales ligeramente exvasadas, borde plano. Asas de lengüeta horizontal con digitaciones. Pasta gris con puntos blancos y mica laminada. Superficie interior amarronada y exterior ennegrecida. Asimilable a Reynolds 7 (1985).

145.-CP-4369-184-23: Borde de un cuenco de cocina tosca importada, modelada a mano o torno lento, con paredes redondeadas y borde entrante. Pasta gris con puntos blancos y mica laminada. Superficie interior amarronada, exterior ennegrecida. Asimilable a Reynolds 5 (1985).

146.-CP-4369-157-7: Pivote de ánfora de producción africana. Pasta laminada de color rojo intenso, con partículas de cal que provocan vacuolas y cristales de cuarzo esporádicos. Superficie externa color rojo intenso.

147.-CP-4369-157-4: Borde no diferenciado de ánfora posible Keay LV. Pasta dura de color rojizo anaranjado con partículas de cal, cristales de cuarzo esporádicos, partículas de color granate indeterminadas y esporádicas y partículas micáceas plateadas casi imperceptibles. Superficie exterior de color beige amarillento. Db.: $100 \mathrm{~mm}$.

148.-CP-4369-157-1: Borde de ánfora africana Keay LXID. Pasta dura de color anaranjado, con partículas de cal (algunas de ellas de gran tamaño), cristales de cuarzo y micáceos plateados casi imperceptibles. Superficie exterior engobada en blancoamarillento. Db.: $120 \mathrm{~mm}$.

149.-CP-4369-157-2: Borde exvasado de sección triangular de ánfora. Forma indeterminada. Pasta dura, granulosa, de color marrón rojizo con partículas de cal, cristales de cuarzo abundantes, partículas oscuras indeterminadas y micáceas plateadas de tamaño pequeño. Superficie exterior color marrón rojizo. Db.: $90 \mathrm{~mm}$.

150.-CP-4369-159-3: Borde y arranque superior de asa de ánfora oriental Keay LIIIC. Pasta granulosa de color beige anaranjado con partículas de cal, de ferromagnesio negro, cristales de cuarzo muy esporádicos y partículas micáceas plateadas casi imperceptibles. Superficie exterior de color beige amarillento. Db.: $110 \mathrm{~mm}$.

151.-CP-4369-159-4: Borde y arranque superior de asa de ánfora oriental Keay LIIIB. Pasta granulosa de color beige anaranjado con partículas de cal esporádicas, partículas de ferromagnesio negro, cristales de cuarzo muy esporádicos y partículas micáceas plateadas casi imperceptibles. Superficie exterior de color beige amarillento. $\mathrm{Db} .: 110 \mathrm{~mm}$.

152.-CP-4369-159-1: Borde, asas y hombro con pivote de anforilla de producción africana tipo 
spatheion. Pasta de tacto rugoso color anaranjado con partículas de cal abundantes que producen poros en la superficie y micáceas plateadas casi imperceptibles. Superficie exterior muy porosa de color anaranjado que presenta signos de un evidente espatulado vertical. Db.: $60 \mathrm{~mm}$.

\section{FASE 10.4 (fig. 9)}

153.-CP-4348-127-1: Perfil completo de un plato de T. S. Africana Clara D, Hayes 99 C, pasta y engobe D2. Db.: 190 mm., Dp.: 90 mm., H.: $56 \mathrm{~mm}$.

154.-CP-4348-127-2: Borde de T. S. Africana Clara D, Hayes $99 \mathrm{~B} / \mathrm{C}$, pasta y engobe D2.

155.-CP-4348-127-3: Borde de T. S. Africana Clara D, Hayes $99 \mathrm{~B}$, pasta y engobe D2. Db.: $180 \mathrm{~mm}$

156.-CP-4345-127-6: Borde de T. S. Africana Clara D, Hayes 99 A, pasta y engobe D2. Db.: $164 \mathrm{~mm}$.

157.-CP-4345-127-1: Borde de T. S. Africana Clara D, Hayes 104 C, pasta y engobe D2. Db.: $300 \mathrm{~mm}$.

158.-CP-4345-127-2: Borde de T. S. Africana Clara D, Hayes 90/105, pasta y engobe D2. Db.: $290 \mathrm{~mm}$.

159.-CP-4348-127-4: Base de T. S. Africana Clara D, Hayes 93, pasta y engobe D2.

160.-CP-4345-176-5: Borde y moldura del cuello de jarra ibicenca Ramón RE 0204B. Pasta anaranjada bien depurada con desgrasantes blancos y pequeños. Superficie externa beige anaranjada. Decoración ondulada a peine y anillos acanalados en el cuello. Decorada a peine. Db.: $46 \mathrm{~mm}$.

161.-CP-4348-176-6: Borde de una jarra en cerámica común. Pasta beige rosada con puntos blancos. Superficie exterior con engobe beige amarillento. $\mathrm{Db}$.: $100 \mathrm{~mm}$.

162.-CP-4348-176-4: Borde de un cuenco de vajilla de mesa en cerámica común. Pasta anaranjada clara con puntos blancos. Superficie exterior con engobe beige amarillento. Db.: $184 \mathrm{~mm}$.

163.-CP-4348-184-1: Borde de una olla de cocina tosca de producción local. Pasta rojiza. Superficie interior rojiza y exterior ennegrecida. Forma Cartagena 1.4. Db.: $186 \mathrm{~mm}$.

164.-CP-4348-184-2: Borde de una olla de cocina tosca de producción local. Pasta rojiza. Superficie interior rojiza y exterior con engobe marrón ennegrecido. Forma Cartagena 1.2. Db.: $162 \mathrm{~mm}$.

165.-CP-4348-184-5: Borde de una olla de co- cina tosca de producción local. Pasta rojiza. Superficie interior rojiza y exterior con engobe marrón ennegrecido. Forma Cartagena 3.3. Db: $152 \mathrm{~mm}$.

166.-CP-4348-184-8: Borde de una olla de cocina tosca de producción local. Pasta rojiza. Superficie interior rojiza y exterior ennegrecida. Forma Cartagena 3.1. Db.: $160 \mathrm{~mm}$.

167.-CP-4345-184-6: Borde de olla de cerámica tosca de producción local. Pasta marrón. Superficie interior marrón, exterior ennegrecida. Forma 5. Db.: $252 \mathrm{~mm}$.

168.-CP-4345-184-1: Perfil completo de una cazuela de cocina tosca de producción local. Pasta marrón rojiza. Superficie interior rojiza, exterior ennegrecida. Forma Cartagena 11. H.: $73 \mathrm{~mm}$.

169.-CP-4348-184-4: Perfil completo de una cazuela de cocina tosca de producción local. Pasta rojiza con el núcleo gris claro. Superficie interior rojiza, exterior engobado en marrón ennegrecido. Forma Cartagena 12.2. H.: $60 \mathrm{~mm}$.

170.-CP-4348-184-3: Perfil completo de una cazuela de cocina tosca de producción local. Pasta rojiza. Superficie interior rojiza, exterior engobe marrón ennegrecido. Forma Cartagena 12.2. H.: $53 \mathrm{~mm}$.

171.-CP-4345-159-1: Borde y arranque de asa de jarra de cerámica común. Pasta depurada de color marrón rojizo con puntos blancos de pequeño tamaño. Superficie exterior de color rojizo. Db.: $110 \mathrm{~mm}$.

172.-CP-4345-157-1: Borde de ánfora africana Keay LXIIB. Pasta dura de color anaranjado con partículas de cal, cristales de cuarzo y micas plateadas. Superficie externa color beige anaranjado. Db.: $104 \mathrm{~mm}$.

173.-CP-4348-159-2: Borde de una anforita de salazones africana tipo spatheion, Keay XXVIG. Pasta anaranjada con puntos blancos, exterior engobado en beige amarillento. Db.: $62 \mathrm{~mm}$.

174.-CP-4348-159-1: Apice de una anforita de salazones africana tipo spatheion. Pasta anaranjada rosada con puntos blancos, exterior engobado en beige amarillento.

\section{FASE 10.3 (figs. 10 y 11)}

175.-CP-4301-127-3: Borde de T. S. Africana Clara D, Hayes 105, pasta y engobe D2.

176.-CP-4354-127-4: Borde de T. S. Africana

Clara D, Hayes 105, pasta y engobe D2.

177.-CP-4327-127-1: Borde de T. S. Africana Clara D, Hayes 99C, pasta y engobe D2. Db.: $160 \mathrm{~mm}$. 


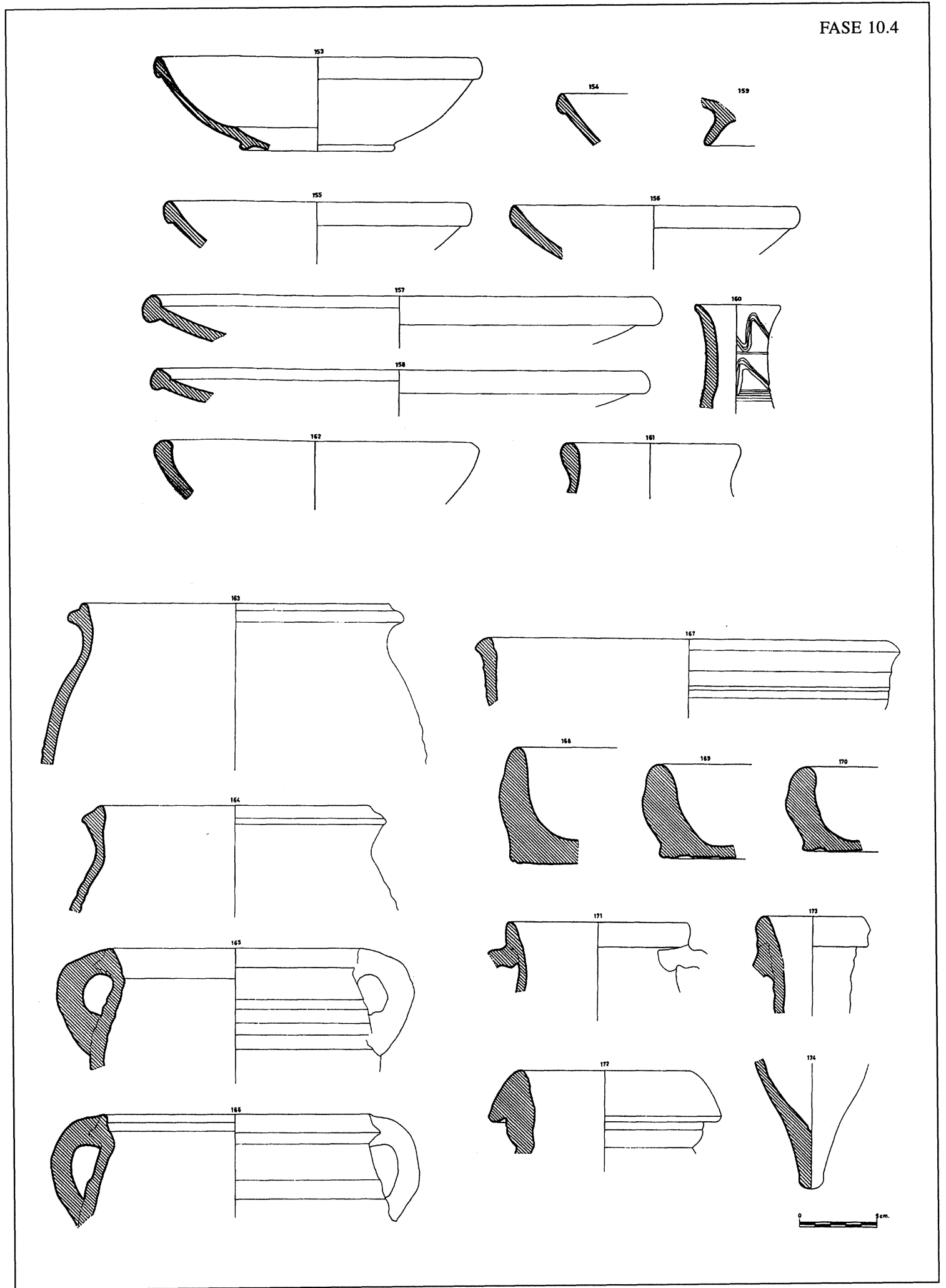

Figura 9 


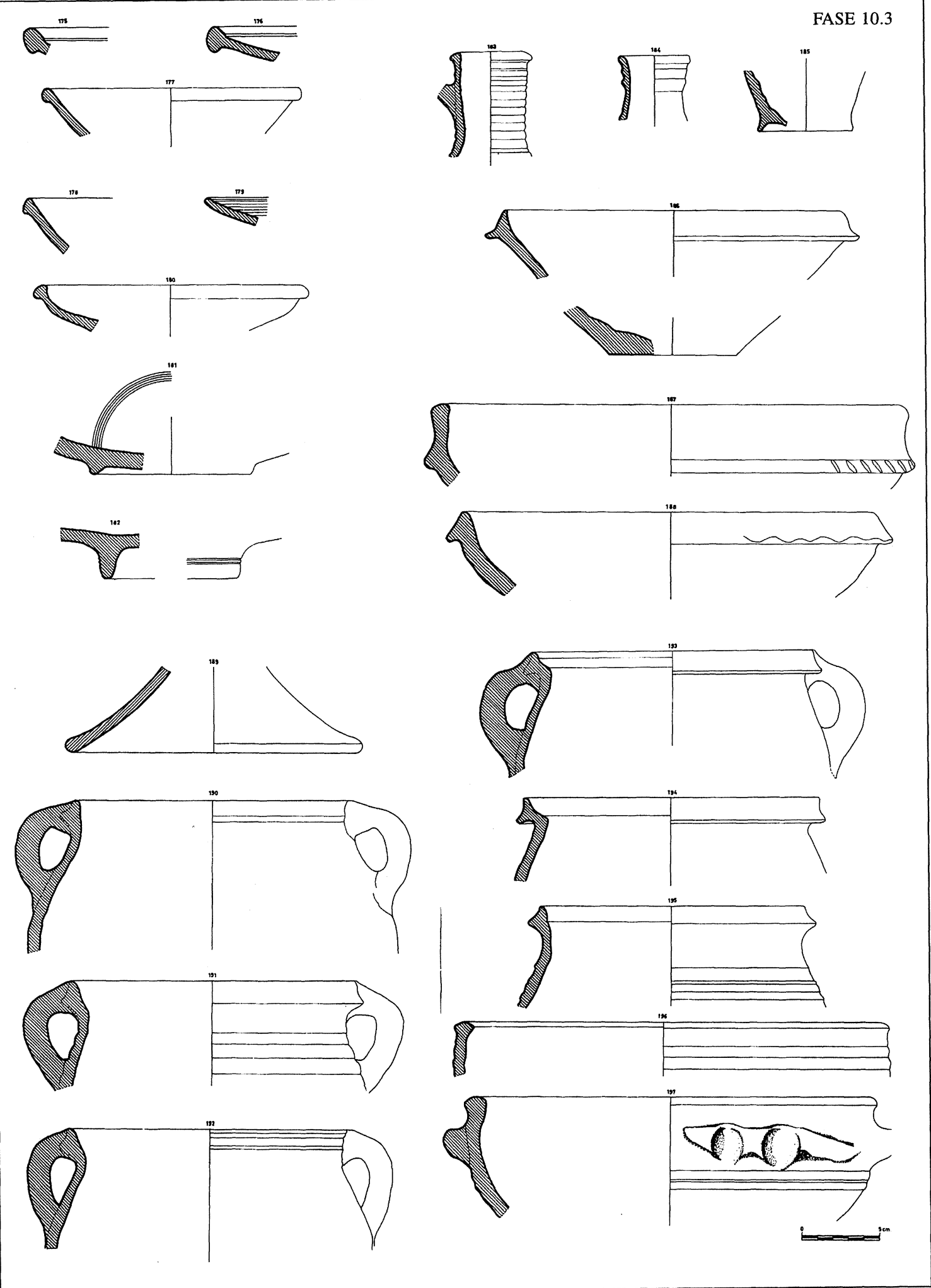

Figura 10 


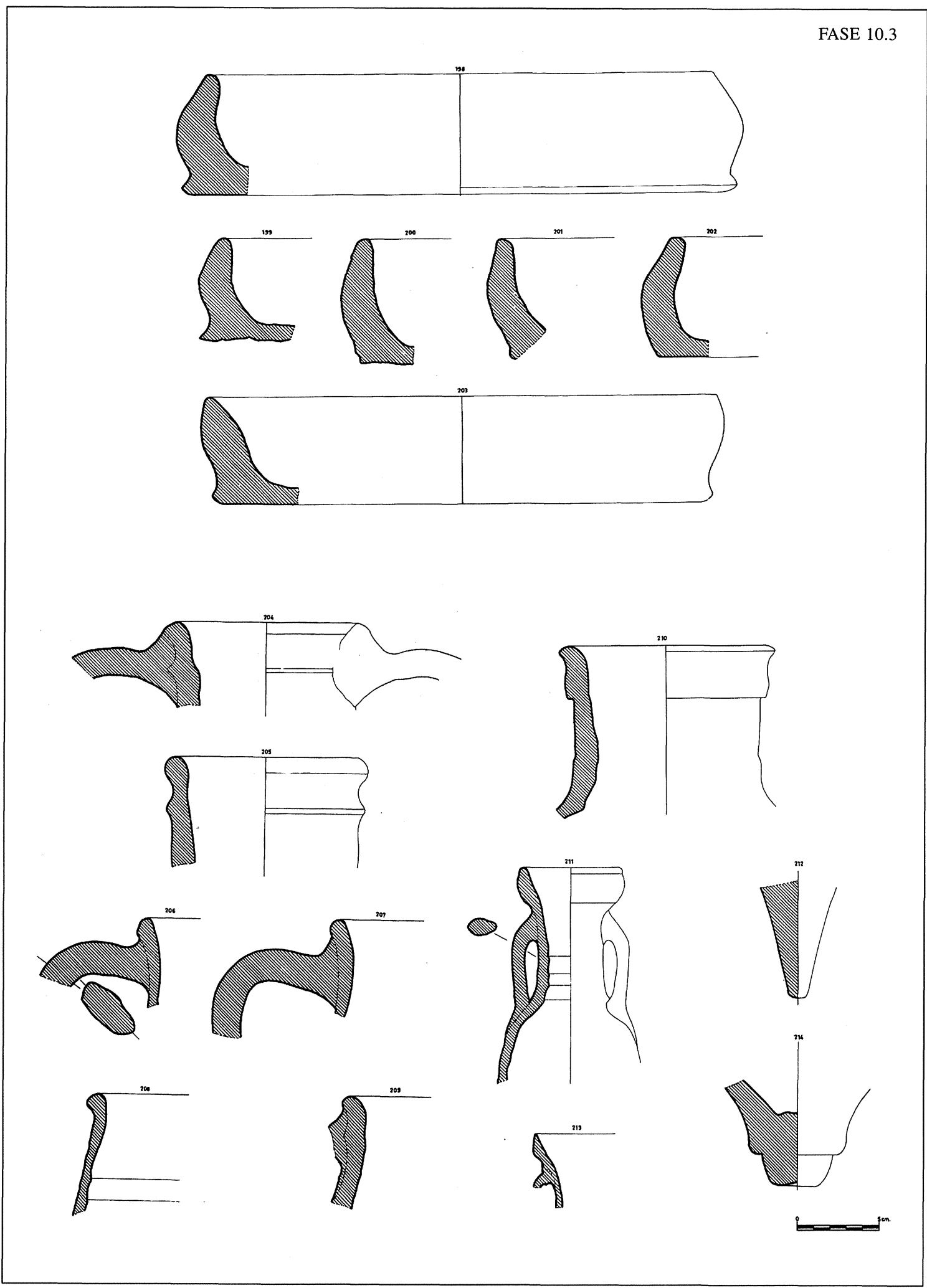

Figura 11 
178.-CP-4354-127-2: Borde de T. S. Africana Clara D, Hayes $99 \mathrm{C}$, pasta y engobe D1.

179.-CP-4354-127-5: Borde de T. S. Africana Clara D, Hayes 109, decoración de bandas espatuladas concéntricas en el interior del plato.

180.-CP-4354-127-1: Borde de T. S. Africana Clara D, Hayes 93/108, pasta y engobe D1. Db.: $160 \mathrm{~mm}$.

181.-CP-4301-127-1: Fondo de T. S. Africana Clara D, Hayes $104 \mathrm{C}$, pasta y engobe D2. Dp.: $100 \mathrm{~mm}$.

182.-CP-4301-127-2: Fondo de T. S. Africana Clara D, Hayes 105, pasta y engobe D2.

183.-CP-4327-176-2: Borde, cuello y arranque de asa de una jarrita monoansada de cerámica común. Pasta granulosa de color beige anaranjado con puntos blancos que provocan poros abundantes, cristales de cuarzo y partículas oscuras indeterminadas. Superficie externa muy porosa engobada en color beige amarillento. $\mathrm{Db} .: 42 \mathrm{~mm}$.

184.-CP-4354-176-1: Borde de una jarrita africana. Pasta anaranjada con puntos blancos. Superficie interior anaranjada, exterior con engobe beige amarillento muy perdido. Similar a Fulford (1984), fig. 79.4.6. Db.: $44 \mathrm{~mm}$.

185.-CP-4327-176-3: Fondo anular y galbo de jarra de cerámica común. Pasta marrón anaranjada con inclusiones de puntos blancos y micas plateadas, ambos de tamaño muy pequeño. Superficie exterior alisada y de color marrón anaranjado. Dp.: $60 \mathrm{~mm}$.

186.-CP-4354-177-2: Borde y fondo de un mortero de cerámica común africana. Pasta anaranjada muy depurada con el núcleo algo rosado, puntos finos de color blanco y marrón. Superficie interior anaranjada y exterior con engobe beige rosado. En el fondo interno, incrustaciones de piedras abrasivas. Db.: $210 \mathrm{~mm}$., Dp.: $80 \mathrm{~mm}$.

187.-CP-4354-177-1: Borde de un mortero de cerámica común. Pasta rojo-anaranjado con desgrasantes de esquistos grises, puntos blancos y marrón oscuro. Superficies con engobe beige. La composición de la pasta es similar a la producción tosca local. Db.: $290 \mathrm{~mm}$.

188.-CP-4327-177-1: Borde con visera de mortero de cerámica común. Pasta depurada de color rojizo-anaranjado con puntos blancos y micas plateadas. Superficie externa color rojizo anaranjado. Db.: $252 \mathrm{~mm}$.

189.-CP-4301-184-1: Borde de una tapadera de cocina tosca de producción local. Pasta rojiza. Superficie interior rojiza y exterior ennegrecida. Forma Cartagena 14.2. Db.: $184 \mathrm{~mm}$.

190.-CP-4301-184-8: Borde de una olla de co- cina tosca de producción local. Pasta rojiza. Superficie interior rojiza y exterior ennegrecida. Forma Cartagena 1.4. Db.: $170 \mathrm{~mm}$.

191.-CP-4364-184-4: Borde de una olla de cocina tosca de producción local. Pasta rojiza. Superficie interior rojiza y exterior ennegrecida. Forma Cartagena 3.3. Db.: $180 \mathrm{~mm}$.

192.-CP-4327-184-3: Borde de una olla de cocina tosca de producción local. Pasta marrón rojiza. Superficies alisadas rojizas, exterior ennegrecido. Forma Cartagena 3.2. Db.: $176 \mathrm{~mm}$.

193.-CP-4364-184-2: Borde de una olla de cocina tosca de producción local. Pasta rojiza. Superficie interior rojiza y exterior ennegrecida. Forma Cartagena 3.1. Db.: $180 \mathrm{~mm}$.

194.-CP-4354-184-2: Borde de una olla de cocina tosca de producción local. Pasta rojiza. Superficie interior rojiza y exterior ennegrecida. Forma Cartagena 3.1. Db.: $190 \mathrm{~mm}$.

195.-CP-4354-184-3. Borde de una olla de cocina tosca de producción local. Pasta rojiza. Superficies alisadas rojizas, exterior ennegrecido. Forma Cartagena 3.2. Dimensiones. Db.: $170 \mathrm{~mm}$.

196.-CP-4354-184-5: Borde de una olla de cocina tosca de producción local. Pasta rojiza. Superficie interior rojiza y exterior ennegrecida. Forma Cartagena 4.1. Db.: $270 \mathrm{~mm}$.

197.-CP-4301-184-3: Borde de un cuenco de cocina tosca de producción local, con asa aplicada con digitaciones. Pasta rojiza. Superficie interior rojiza y exterior ennegrecida. Forma Cartagena 5. Db.: $252 \mathrm{~mm}$.

198.-CP-4354-184-8: Borde de una cazuela de cocina tosca de producción local. Pasta rojiza. Superficie interior rojiza y exterior ennegrecida. Forma Cartagena 11. Db.: 310 mm., Dp.: 324 mm., H.: $74 \mathrm{~mm}$

199.-CP-4327-184-1: Perfil completo de una cazuela de cocina tosca de producción local. Pasta marrón rojiza. Superficie interior rojiza y exterior ennegrecida. Forma Cartagena 12.2. Db.: 360 mm., Dp.: 284 mm., H.: $63 \mathrm{~mm}$.

200.-CP-4301-184-4: Perfil completo de una cazuela de cocina tosca de producción local. Pasta rojiza. Superficie interior rojiza y exterior ennegrecida. Forma Cartagena 12.2. H.: $75 \mathrm{~mm}$.

201.-CP-4301-184-2: Perfil completo de una cazuela de cocina tosca de producción local. Pasta rojiza. Superficie interior rojiza y exterior ennegrecida. Forma Cartagena 11. H.: $73 \mathrm{~mm}$.

202.-CP-4364-184-5: Perfil completo de una cazuela de cocina tosca de producción local. Pasta rojiza. Superficie interior y exterior con engobe gris claro. Forma Cartagena 12.1. H.: $72 \mathrm{~mm}$. 
203.-CP-4354-184-9: Borde de una cazuela de cocina tosca de producción local. Pasta rojiza. Superficie interior rojiza y exterior ennegrecida. Forma Cartagena 12.1. Db.: 310 mm., Dp.: 290 mm., H.: $65 \mathrm{~mm}$.

204.-CP-4301-159-3: Borde y arranque de asa de ánfora oriental Keay LIIIA. Pasta granulosa de color beige, con numerosas inclusiones. Superficie externa color beige rosado. Db.: $90 \mathrm{~mm}$.

205.-CP-4301-159-2: Borde de ánfora oriental Keay LIIIA. Pasta granulosa de color beige-anaranjado, con numerosas inclusiones. Superficie externa color anaranjado claro. Db.: $90 \mathrm{~mm}$.

206.-CP-4354-159-2: Borde y arranque de asa de ánfora de producción africana. Pasta depurada de color rojizo con partículas de cal que provocan poros y partículas micáceas plateadas de tamaño pequeño. Superficie exterior engobada en beige amarillento. Db.: $90 \mathrm{~mm}$.

207.-CP-4354-159-3: Borde y arranque de asa de ánfora de tipo indeterminado. Pasta dura de color rojizo, con partículas de cal que provocan poros y vacuolas, esquistos grisáceos laminados y partículas micáceas plateadas casi imperceptibles. Superficie exterior de color rojizo.

208.-CP-4354-159-7: Borde de ánfora oriental. Pasta granulosa de color anaranjado, con partículas de cal, inclusiones oscuras indeterminadas y partículas micáceas plateadas casi imperceptibles. Superficie exterior de color beige-amarillento. Db.: $100 \mathrm{~mm}$.

209.-CP-4354-159-1: Borde y arranque de asa de ánfora oriental Keay LIIIA. Pasta granulosa de color beige-amarillento, con numerosas inclusiones. Superficie exterior de color beige-amarillento. Db.: $90 \mathrm{~mm}$.

210.-CP-4364-157-8: Borde de ánfora Keay LIII. Pasta granulosa de color anaranjado con inclusiones de cal y ferromagnesio negro, con partículas micáceas plateadas y doradas casi imperceptibles. Superficie externa de color anaranjado. Db.: $120 \mathrm{~mm}$.

211.-CP-4327-159-1: Borde engrosado, cuello y asas de anforilla de producción africana tipo spatheion, Keay XXVIC. Pasta dura de color beige anaranjado con partículas de cal que provocan vacuolas en superficie e inclusiones de color granate indeterminadas. Superficie externa color beige amarillento. Db.: $59 \mathrm{~mm}$.

212.-CP-4354-159-19: Pivote cilíndrico de ánfora de producción africana tipo spatheion. Pasta granulosa de color amarillento con partículas de cal esporádicas que provocan poros en superficie y cristales de cuarzo. Superficie externa anaranjada.
213.-CP-4354-159-18: Borde, cuello y arranque de asa de ánfora de producción africana tipo spatheion, Keay XXVIG. Pasta granulosa de color amarillento con partículas de cal esporádicas que provocan poros en superficie y cristales de cuarzo. Superficie externa amarillenta. Db.: $60 \mathrm{~mm}$.

214.-CP-4364-157-1: Pivote anular de ánfora africana Keay LXI- LXIII. Pasta dura de color anaranjado con inclusiones de cal que provocan vacuolas. Superficie externa de color anaranjado.

\section{FASE 10.2 (figs. 12-20)}

Habitación 2 (figs. 12-16):

215.-CP-4299-127-1: Borde de T. S. Africana Clara D, Hayes 99 C, pasta y engobe D2.

216.-CP-4299-171-1: Borde de una cazuela africana de pátina cenicienta Hayes 196. Pasta anaranjada, superficie interior anaranjada y exterior pátina cenicienta. Db.: $190 \mathrm{~mm}$.

217.-CP-4299-176-1: Borde de un oinochoe. Pasta africana, color anaranjado con partículas blancas y rojizas. Superficies alisadas de color anaranjado claro. Fulford (1984) fig. 79.9.2.

218.-CP-4299-184-1: Perfil completo de una cazuela de cocina tosca de producción local. Pasta rojiza. Superficie interior rojiza y exterior ennegrecida. Forma Cartagena 12.2. Db.: 300 mm., Dp.: $308 \mathrm{~mm}$., H: $61 \mathrm{~mm}$.

219.-CP-4299-184-2: Borde de una olla de cocina tosca de producción local. Pasta rojiza. Superficie interior rojiza, exterior engobe marrón claro. Forma Cartagena 2.2. Db.: $170 \mathrm{~mm}$.

220.-CP-4299-184-3: Borde de una ollita de cocina tosca. Pasta gris oscura. Superficie interior marrón grisácea, exterior ennegrecida. Factura muy tosca modelada a mano. Db.: $110 \mathrm{~mm}$.

221.-CP-4299-157-4: Borde, asas y hombro de un ánfora africana Keay XXXII. Pasta blanda de color beige amarillento con partículas de cal. Superficie exterior beige-amarillento. Presenta grafito inciso « MXX». Db.: $98 \mathrm{~mm}$.

222.-CP-4299-157-6: Ánfora africana completa Keay XXXII. Pasta dura de color anaranjado intenso. Inclusiones abundantes de cal. Superficie exterior beige-anaranjada. $\mathrm{Db}$.: $98 \mathrm{~mm}$.

223.-CP-4299-157-7: Ánfora africana completa (salvo el pivote) Keay LXI. Pasta dura de color anaranjado, con inclusiones de cal muy gruesas que provocan vacuolas y partículas micáceas plateadas casi imperceptibles. Superficie externa engobada en beige amarillento. $\mathrm{Db} .: 130 \mathrm{~mm}$. 


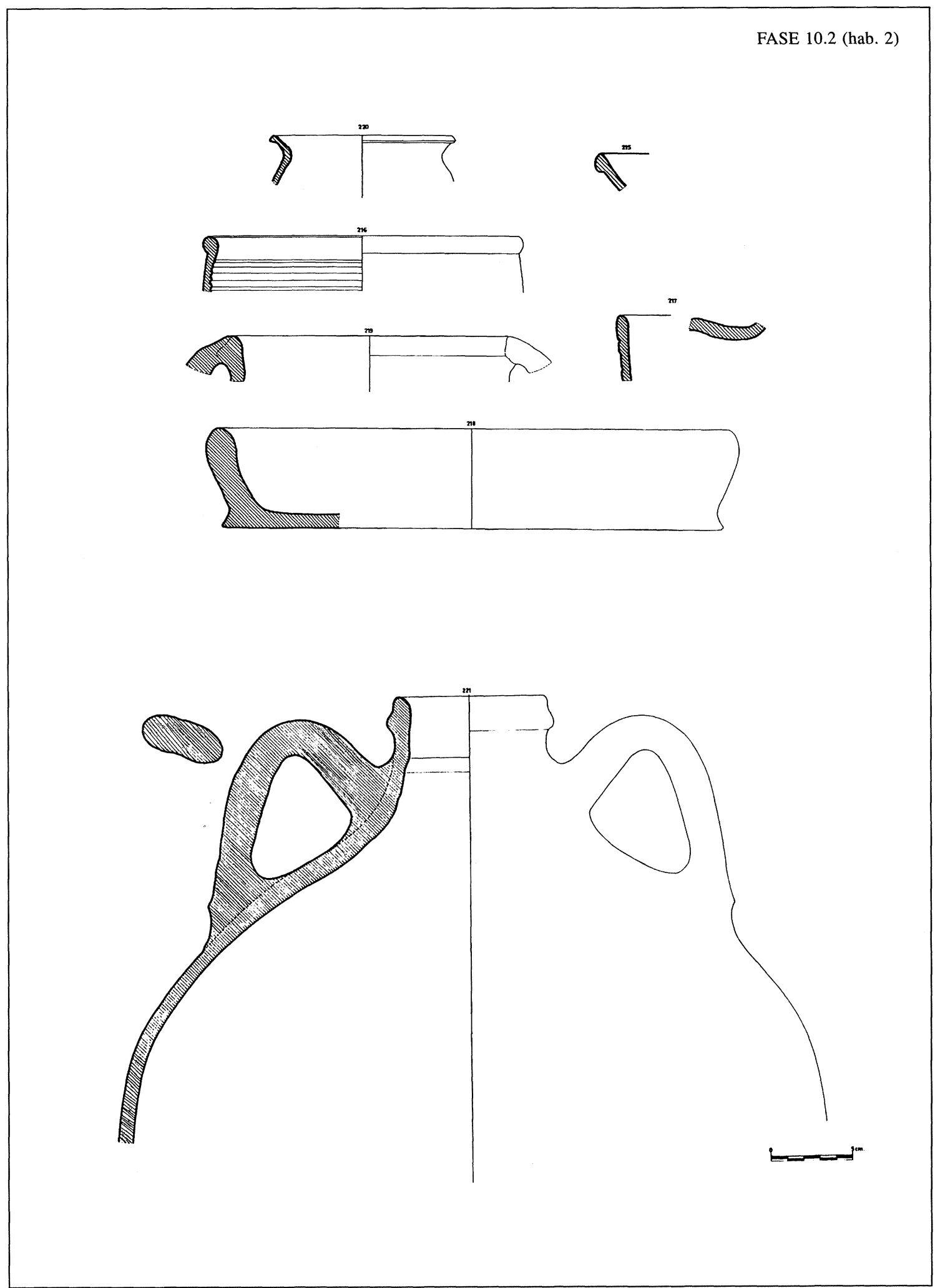

Figura 12 


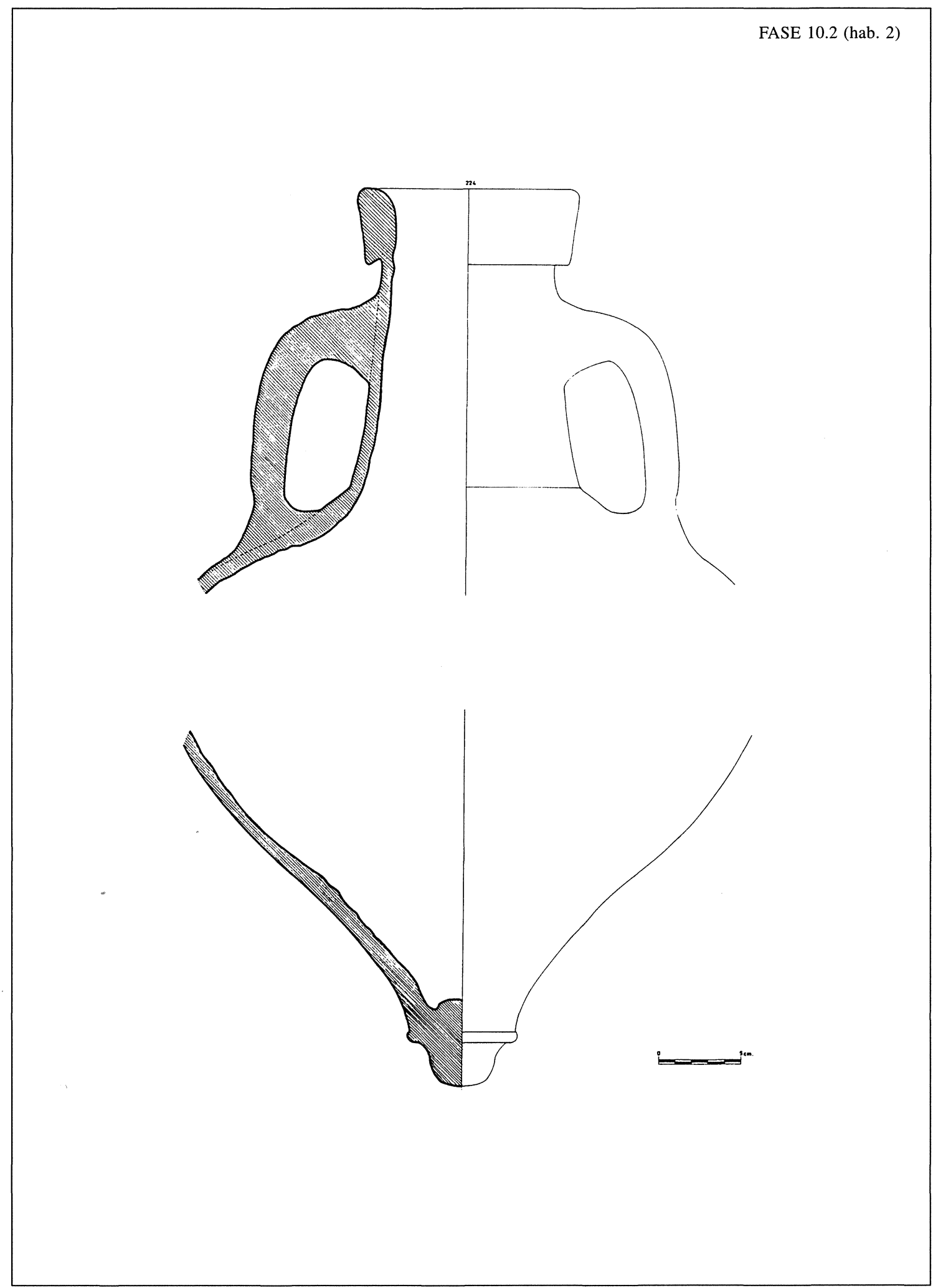

Figura 13 


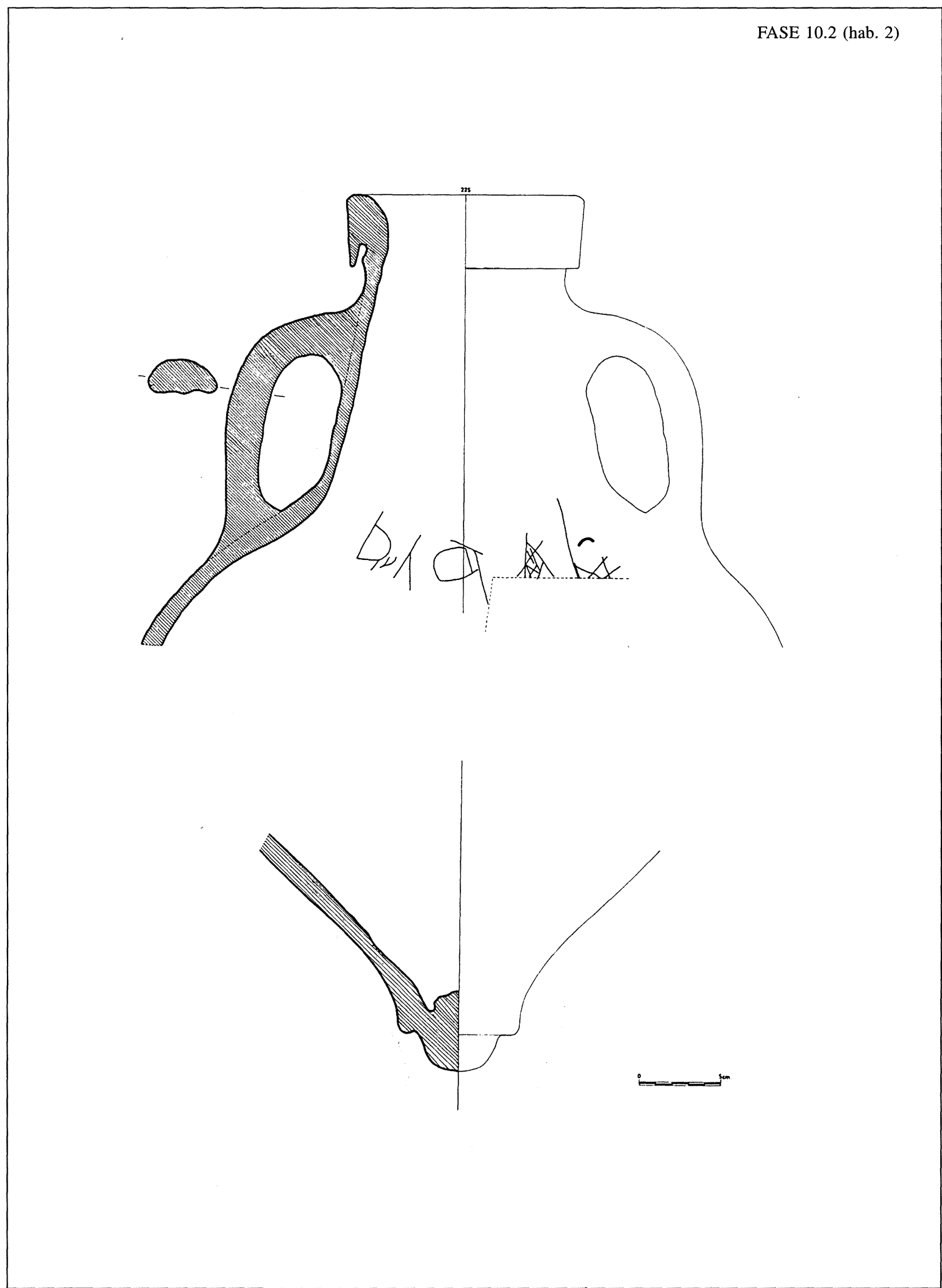

Figura 14 


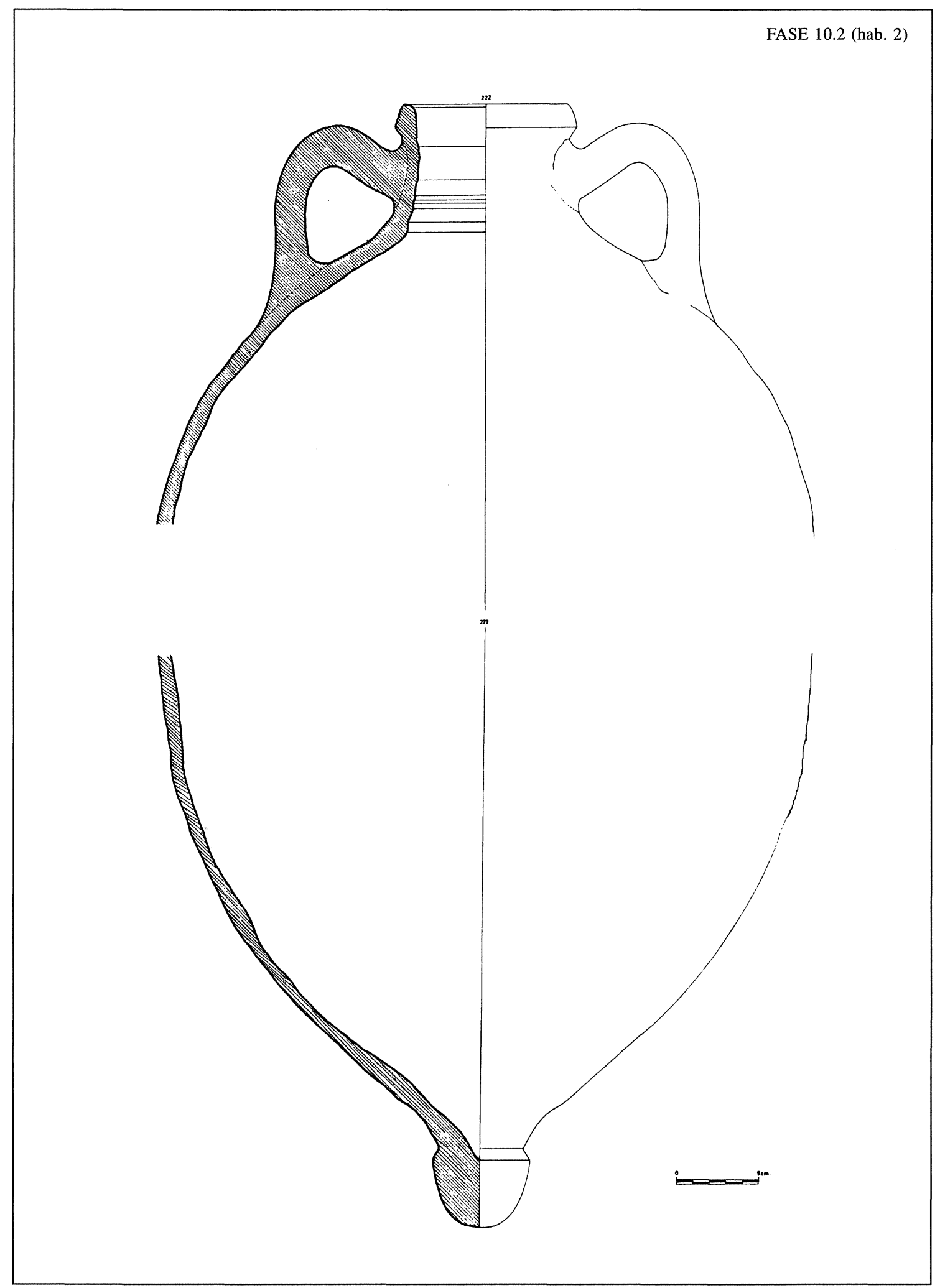

Figura 15 


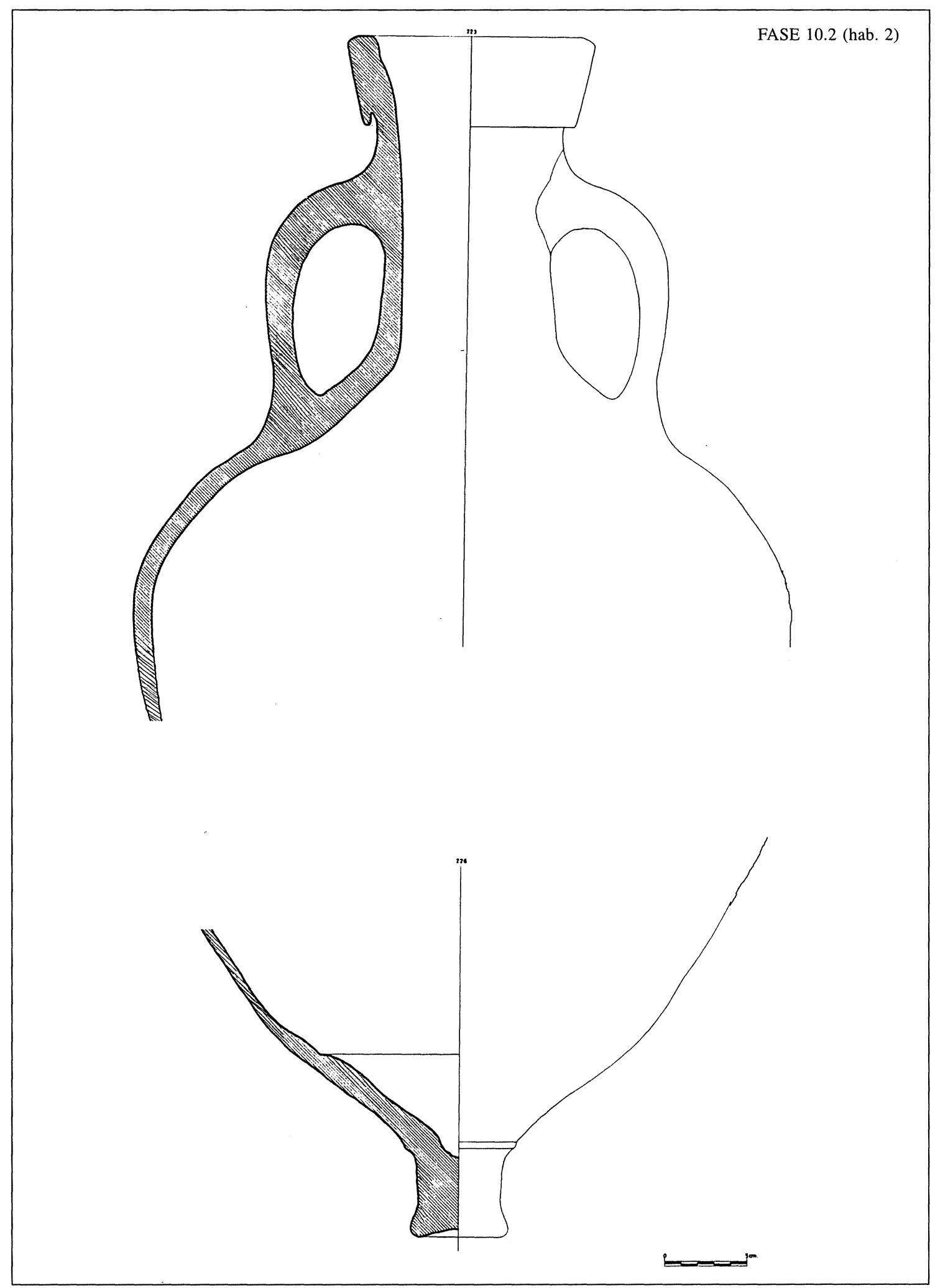

Figura 16 
224.-CP-4299-157-8: Ánfora africana completa Keay LXI. Pasta dura de color anaranjado, con inclusiones de cal muy gruesas que provocan vacuolas, cristales de cuarzo muy esporádicos y partículas micáceas plateadas casi imperceptibles. Superficie externa engobada en beige amarillento. Db.: $124 \mathrm{~mm}$.

225.-CP-4299-157-2: Cuerpo de ánfora de procedencia africana posible Keay LXI. Pasta dura de color anaranjado, con partículas de cal y cristales de cuarzo. Superficie exterior engobada en amarillentoverdoso.

225bis.-CP-4299-157-3: Borde de ánfora africana Keay LXI. Pasta dura de color anaranjado, con inclusiones de cal muy gruesas que provocan vacuolas y partículas micáceas plateadas casi imperceptibles. Superficie externa engobada en beige amarillento. Presenta grafito inciso. Db.: $130 \mathrm{~mm}$.

226.-CP-4299-157-11: Cuerpo de ánfora de procedencia africana posible Keay LXI. Pasta dura de color anaranjado intenso, con partículas de cal, cristales de cuarzo y micas plateadas casi imperceptibles. Superficie exterior engobada en beige amarillento.

\section{Habitación 3 (fig. 17)}

227.-CP-4298-184-2: Borde y pared de una olla de cocina tosca de producción local. Torneado tosco o quizás modelada a mano. Pasta rojiza. Superficie interior y exterior con un ligero engobe amarronado, al exterior ennegrecido. Forma Cartagena 1.1. Db.: $210 \mathrm{~mm}$.

228.-CP-4298-184-1: Perfil completo de un cuenco de cocina tosca de producción local. Modelada a mano, paredes verticales ligeramente exvasadas, borde plano. Asas de lengüeta horizontal. Pasta rojiza quemada. Superficie interior amarronada, exterior ennegrecida. Forma 13. Db.: $245 \mathrm{~mm}$, Dp.:170 mm., H.: $150 \mathrm{~mm}$.

229.-CP-4298-157-2: Pivote de ánfora de producción africana. Pasta dura de color rojo intenso con partículas de cal, cristales de cuarzo y micas plateadas imperceptibles. Superficie externa espatulada y engobada en beige amarillento.

\section{Patio triangular 4 (fig. 18)}

230.-CP-4308-127-1: Fondo de T. S. Africana Clara D, Hayes 99 C, pasta y engobe D2. Dp.: $90 \mathrm{~mm}$.

231.-CP-4308-127-3: Borde de T. S. Africana Clara D, Hayes 109, decoración de bandas espatuladas concéntricas en el interior del plato. Db.: $190 \mathrm{~mm}$.
232.-CP-4316-127-1: Borde de T. S. Africana Clara D, Hayes 91 D, pasta y engobe D2. Db.: $130 \mathrm{~mm}$.

233.-CP-4308-176-1: Borde de una botella en cerámica común. Pasta anaranjada clara, depurada, con puntos blancos y mica laminada. Superficie exterior con engobe beige claro. Db.: $122 \mathrm{~mm}$.

234.-CP-4308-177-2: Fondo de un mortero en cerámica común. Pasta anaranjada clara, depurada, con puntos blancos y mica. Superficie exterior con engobe beige claro. En el fondo interno, incrustaciones de piedrecillas abrasivas. Probablemente de producción africana. Similar a Fulford (1984), fig. 21. Dp.: $70 \mathrm{~mm}$.

235.-CP-4308-184-2: Borde de un cuenco de cocina tosca de producción local. Pasta rojiza. $\mathrm{Su}-$ perficie interior rojiza y exterior ennegrecida. Forma Cartagena 7. Db.: $240 \mathrm{~mm}$.

236.-CP-4308-184-4: Borde de una olla de cocina tosca de producción local. Pasta rojiza. Superficie interior rojiza y exterior con engobe marrón ennegrecido. Forma Cartagena 2.2. Db.: $220 \mathrm{~mm}$.

237.-CP-4308-184-6: Borde de una cazuela de cocina tosca de producción local. Pasta rojiza con el núcleo gris claro. Superficie interior y exterior con engobe anaranjado claro. Forma Cartagena 12.2. Db.: 296 mm., Dp.: 324 mm., H.: 62 mm.

238.-CP-4308-157-6: Borde, cuello y arranque de asas de ánfora Keay LXI. Pasta dura de color rojizo-anaranjado con inclusiones de cal que provocan poros y vacuolas y micáceas plateadas casi imperceptibles. Superficie externa engobada en beige amarillento. $\mathrm{Db} .: 142 \mathrm{~mm}$.

239.-CP-4316-157-1: Tres fragmentos de borde de ánfora africana Keay LXI. Pasta dura de color anaranjado con inclusiones de cal que provocan vacuolas y micáceas plateadas casi imperceptibles. Superficie externa engobada en color beige-amarillento. Db.: $92 \mathrm{~mm}$.

240.-CP-4308-157-1: Borde, cuello y asas de ánfora africana Keay LXI. Pasta dura de color anaranjado, con inclusiones de cal, cristales de cuarzo y partículas micáceas plateadas casi imperceptibles. Superficie externa engobada en beige amarillento. Presenta grafito inciso: «XIII»، Db.: $120 \mathrm{~mm}$.

241.-CP-4316-157-6: Borde, cuello y asas de un ánfora africana tipo indeterminado. Pasta dura de color anaranjado intenso, con partículas de cal de gran tamaño que provocan numerosas vacuolas, cristales de cuarzo y partículas de color granate esporádicas e indeterminadas. Superficie externa engobada en beige amarillento. $\mathrm{Db} .: 143 \mathrm{~mm}$.

242.-CP-4308-157-2: Pivote con anillo de ánfora africana (LXI-LXII). Pasta dura de color ana- 


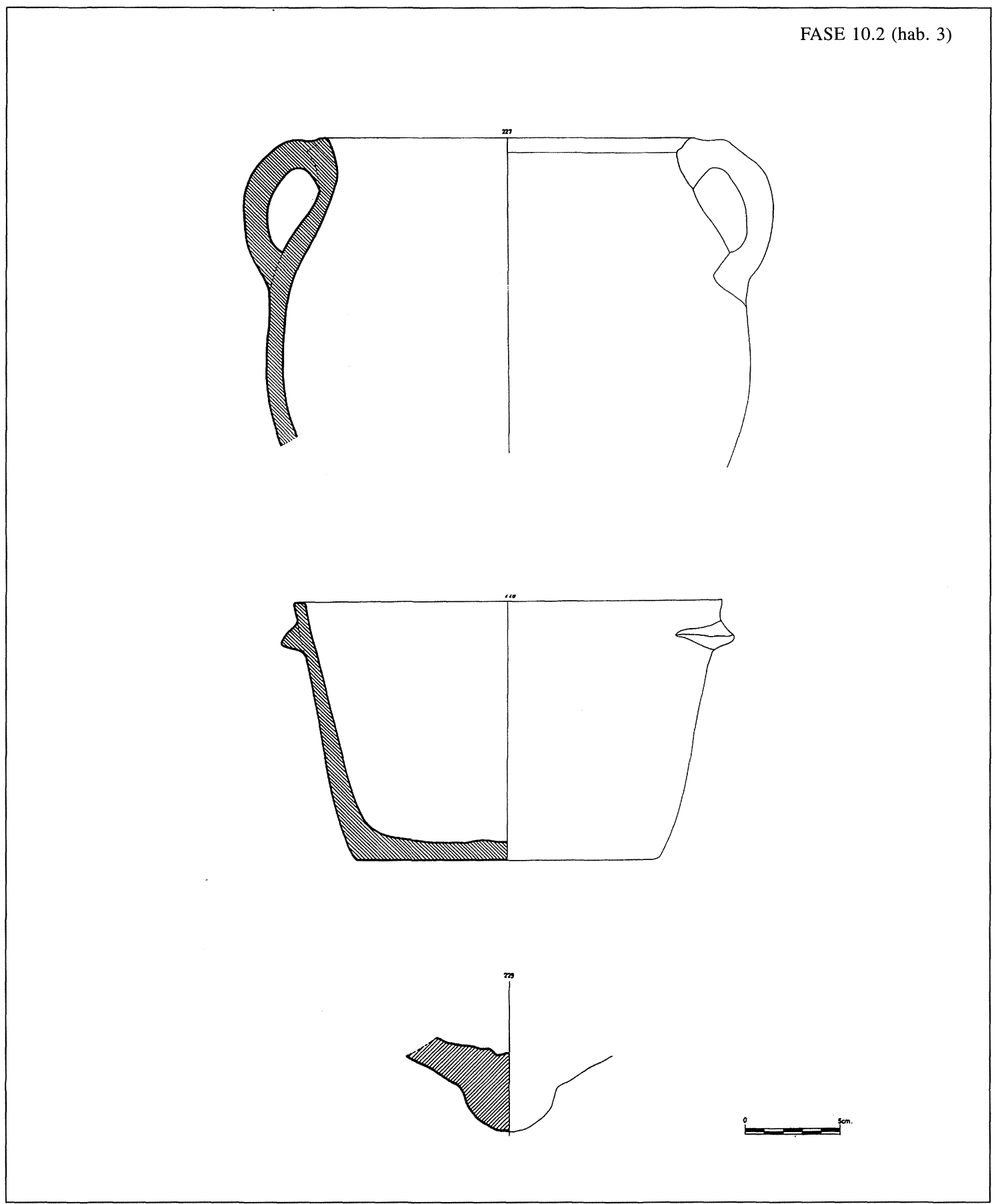

Figura 17

ranjado con poros y vacuolas. Abundantes inclusiones de cal, algunas de ellas de gran tamaño, cristales de cuarzo y partículas micáceas plateadas casi imperceptibles. Superficie externa engobada en beige amarillento, excepto por el extremo del pivote.
Espacio exterior 5 (figs. 19-20)

243.-CP-4310-127-1: Borde de T. S. Africana Clara D, Hayes 99C, pasta y engobe D2. Db.: 180 $\mathrm{mm}$. 


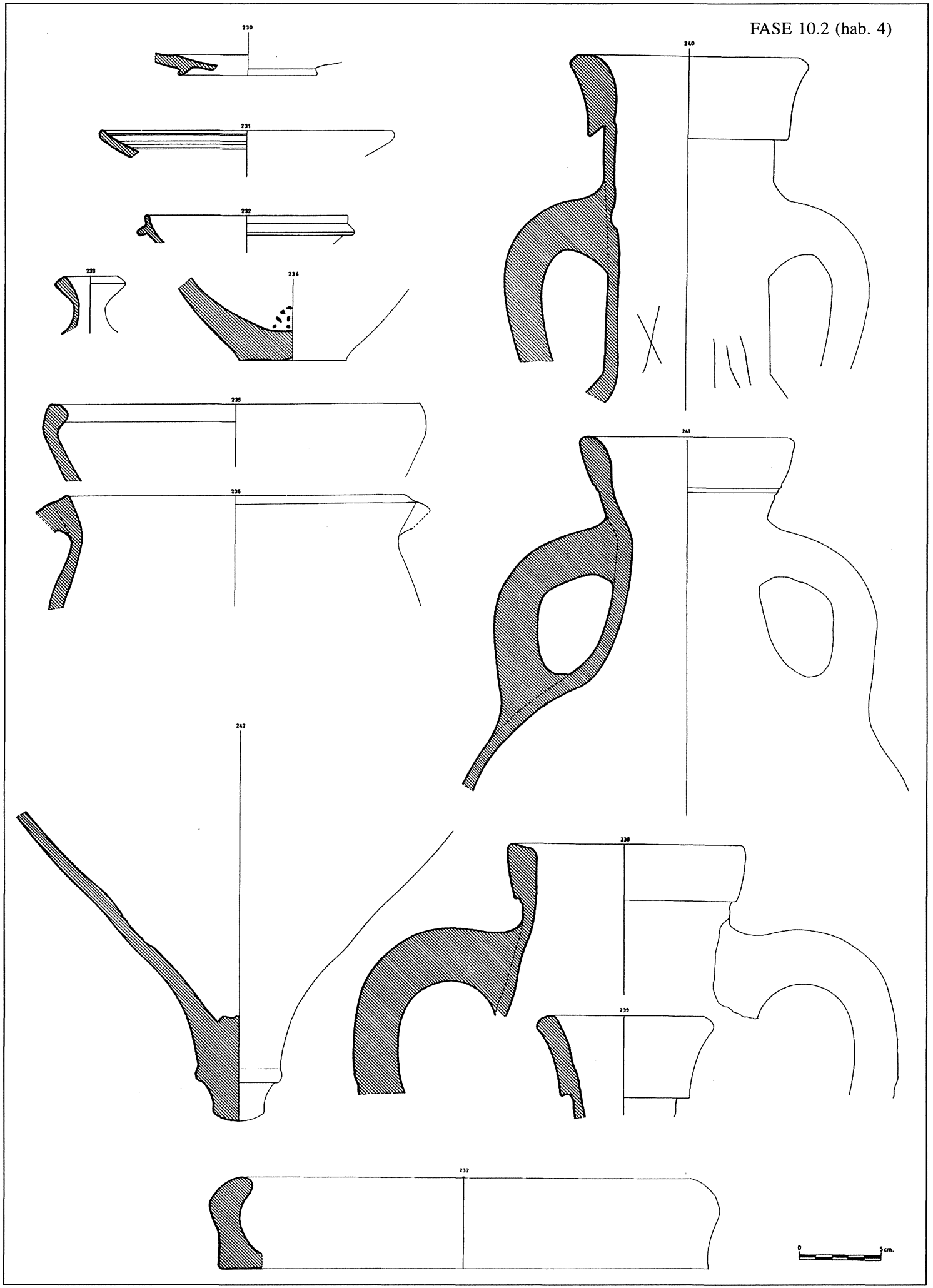

Figura 18 
244.-CP-4310-127-3: Borde de T. S. Africana Clara D, Hayes 93/108, pasta y engobe D2. Db.: $150 \mathrm{~mm}$

245.-CP-4310-127-5: Base de T. S. Africana Clara D, Hayes 105, pasta y engobe D2. Dp.: $178 \mathrm{~mm}$.

246.-CP-4310-175-4: Borde de un cuenco de borde entrante en cerámica común. Pasta anaranjada clara, depurada con puntos blancos y mica. Superficie exterior engobe beige claro. $\mathrm{Db}: 170 \mathrm{~mm}$.

247.-CP-4310-177-1: Borde de un mortero de producción africana. Pasta anaranjada, depurada. Superficie exterior anaranjada, pátina grisácea en la visera del borde. Similar a Fulford (1984), fig. 76.3.1.

248.-CP-4310-176-1: Borde, cuello y asas de jarra/ánfora de tipo indeterminado. Pasta poco depurada de color anaranjado con esquistos grisáceos laminados y partículas indeterminadas oscuras. Presenta marcadas huellas de torno. Superficie exterior de color anaranjado. Db.: $62 \mathrm{~mm}$.

249.-CP-4310-184-3: Borde de una olla de cocina tosca de producción local. Pasta rojiza. Superficie interior rojiza y exterior ennegrecida. Forma Cartagena 1.4. Db.: $190 \mathrm{~mm}$.

250.-CP-4310-184-1: Perfil completo de una cazuela de cocina tosca de producción local. Pasta rojiza. Superficie interior rojiza y exterior ennegrecida. Forma Cartagena 11. Db.: 290 mm., Dp.: 284 mm., H.: $360 \mathrm{~mm}$.

251.-CP-4310-184-12: Borde y base de una olla de cocina tosca probablemente local. Modelada a mano, acabado muy tosco. Borde vuelto, cuerpo esférico y base plana. Pasta gris oscura con desgrasantes gruesos blancos (cuarzo), esquistos y mica fina. Superficies ennegrecidas. Asimilable a la forma Reynolds 7.7 y 8.1 (1985). Db.: 126 mm., Dp.: $110 \mathrm{~mm}$.

252.-CP-4310-157-6: Borde, cuello y asas de ánfora africana Keay LXII. Pasta dura de color anaranjado, con partículas de cal que provocan vacuolas y micas plateadas casi imperceptibles. Superficie externa engobada en beige amarillento y decorada con tres bandas incisas a peine (de $8 \mathrm{~mm}$. cada una). Presenta grafito inciso: PECULIA (?). Db.: $136 \mathrm{~mm}$

253.-CP-4310-157-7: Borde, cuello y asas de ánfora africana Keay LXII. Pasta dura de color ana- ranjado, con partículas de cal que provocan vacuolas y micas plateadas casi imperceptibles. Superficie externa engobada en beige amarillento. Db.: $120 \mathrm{~mm}$.

254.-CP-4310-159-3: Pivote anular de ánfora africana Keay LXI-LXII. Pasta dura de color anaranjado, con partículas de cal que provocan vacuolas y micas plateadas casi imperceptibles. Superficie externa engobada en beige amarillento.

255.-CP-4310-159-14: Ánfora completa de tamaño intermedio y producción oriental. Pasta dura color marrón oscuro con áreas anaranjadas, con abundantes inclusiones de cal de distintos tamaños que provocan poros y vacuolas, micas plateadas en superficie casi imperceptibles. Superficie exterior engobada en beige amarillento y decorada con una gran banda acanalada. Db.: $86 \mathrm{~mm}$.

\section{FASE 10.1 (fig. 20)}

256.-CP-4290-127-1: Fragmento de borde de T. S. Africana Clara D, Hayes 99 B ó C, pasta y engobe D2. Db.: $170 \mathrm{~mm}$.

257.-CP-4290-127-2: Fragmento de borde de T. S. Africana Clara D, Hayes 105, pasta y engobe D2. 258.-CP-4290-171-1: Fragmento de borde de una olla de cocina africana de pátina cenicienta. Pasta marrón anaranjada, con puntos blancos y mica. Superficie interior marrón anaranjada, exterior cenicienta. Similar Atlante I, CVIII, 4.

259.-CP-4290-176-1: Fragmento de borde de un olpe en cerámica común. Pasta anaranjada clara, depurada, con puntos blancos y mica laminada. Superficies anaranjadas. Db.: $60 \mathrm{~mm}$.

260.-CP-4290-176-3: Fragmento de borde de una jarra en cerámica común. Pasta anaranjada clara, depurada, con puntos blancos y mica laminada. Superficies con engobe beige claro. Db.: $122 \mathrm{~mm}$.

261.-CP-4290-184-1: Fragmento de borde de una olla de cocina tosca de producción local. Pasta rojiza. Superficie interior rojiza y exterior ennegrecida. Forma Cartagena 2.2. Db.: $160 \mathrm{~mm}$.

262.-CP-4290-184-10: Fragmento de borde de un cuenco de cocina tosca de producción local. Pasta rojiza. Superficie interior rojiza y exterior ennegrecida. Asa aplicada con digitaciones. Forma Cartagena 7. Db.: $230 \mathrm{~mm}$. 


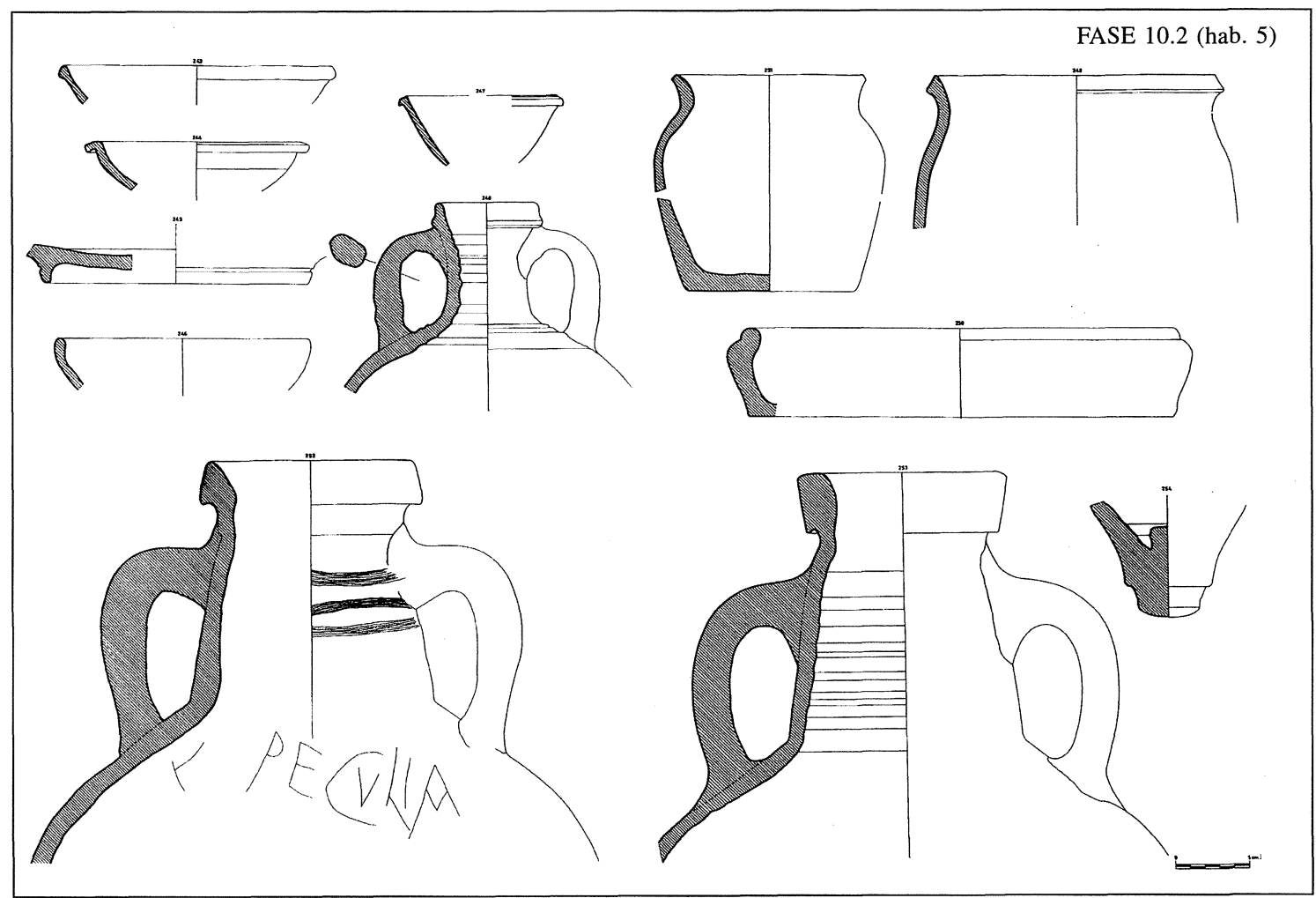

Figura 19

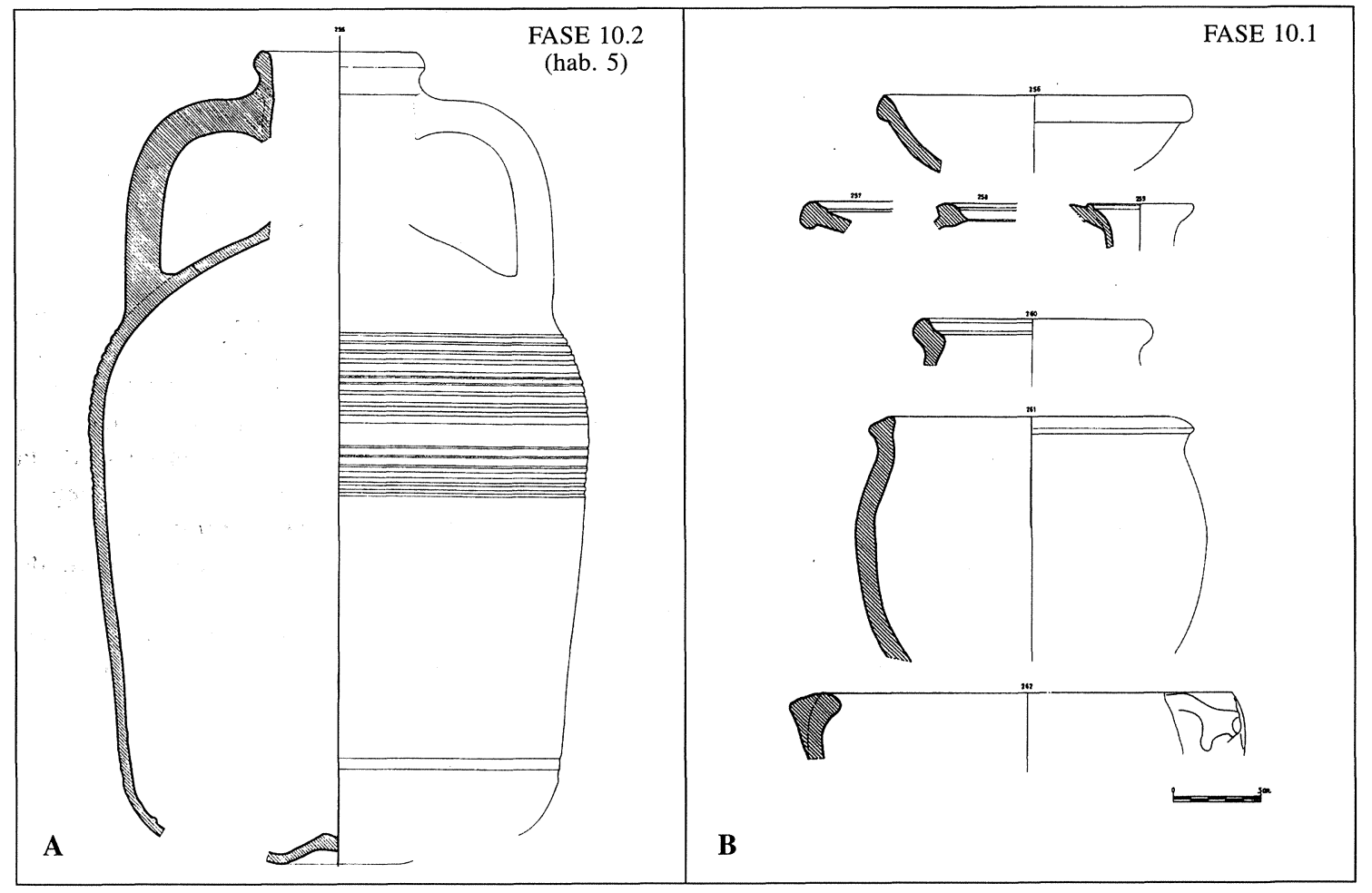

Figura 20 
Tabla 1. Formas de Africana D

\begin{tabular}{|c|c|c|c|c|c|c|}
\hline CRONOLOGÍA & $400-450$ & $475-525$ & $525-535$ & $535-550$ & $\mathbf{5 5 0 - 5 9 0}$ & $590-625$ \\
\hline $\begin{array}{l}\text { FASE } \\
\text { H.61 } \\
\text { H.63 } \\
\text { H.80B } \\
\text { H.89 } \\
\text { H.90 } \\
\text { H.91A } \\
\text { H.91C } \\
\text { H.91D } \\
\text { H.93A } \\
\text { H.93B-108 } \\
\text { H.99A } \\
\text { H.99B } \\
\text { H.99C } \\
\text { H.80B/99 } \\
\text { H.103 } \\
\text { H.104A } \\
\text { H.104B } \\
\text { H.104C } \\
\text { H.105 } \\
\text { H.107 } \\
\text { H.109 }\end{array}$ & $\begin{array}{c}8.2 \\
1 \\
1 \\
\\
1\end{array}$ & $\begin{array}{l}8.1 \\
1 \\
1 \\
\\
1 \\
1 \\
1\end{array}$ & $\begin{array}{c}9.2 \\
1 \\
1 \\
2 \\
1 \\
\\
2 \\
2 \\
1 \\
1\end{array}$ & 3 & $\begin{array}{l}3 \\
2 \\
1 \\
1 \\
3 \\
1\end{array}$ & $\begin{array}{l}1 \\
2 \\
6\end{array}$ \\
\hline
\end{tabular}

Tabla 2. Cerámica común tosca local

\begin{tabular}{|c|c|c|c|c|c|c|}
\hline CRONOLOGÍA & $400-450$ & $475-525$ & $525-535$ & $535-550$ & $550-590$ & $590-625$ \\
\hline $\begin{array}{l}\text { FASES } \\
\text { Forma 1.1 } \\
\text { Forma 1.2 } \\
\text { Forma 1.3 } \\
\text { Forma 2.2 } \\
\text { Forma 2.3 } \\
\text { Forma 2.4 } \\
\text { Forma 3.1 } \\
\text { Forma 3.2 } \\
\text { Forma 3.3 } \\
\text { Forma 4.1 } \\
\text { Forma 4.2 } \\
\text { Forma 4.3 } \\
\text { Forma 5 } \\
\text { Forma } 7 \\
\text { Forma 10 } 10 \\
\text { Forma 11 } \\
\text { Forma 12 } \\
\text { Forma 13 } \\
\text { Forma 14 }\end{array}$ & 8.2 & $\begin{array}{c}8.1 \\
1\end{array}$ & $\begin{array}{l}3 \\
2 \\
2 \\
2 \\
1 \\
1 \\
1\end{array}$ & $\begin{array}{l}1 \\
1 \\
1\end{array}$ & $\begin{array}{c}10.4-5 \\
1 \\
1 \\
2 \\
2\end{array}$ & $\begin{array}{c}10.3-1 \\
1 \\
\\
3 \\
\\
2 \\
2 \\
1\end{array}$ \\
\hline
\end{tabular}

Tabla 3

\begin{tabular}{|c|c|c|c|c|}
\hline FASES & AFRICANA & ÁNFORAS & COMÚN AFRICANA & TOSCA LOCAL \\
\hline $\begin{array}{l}\text { FASE } 8.2 \\
400-450 \\
\text { FASE } 8.1 \\
475-525 \\
\text { FASE } 9.2 \\
525-535 \\
\\
\text { FASE } 9.1 \\
535-550 \\
\text { FASE } 10.5 \\
550-570 \\
\text { FASE } 10.4 \\
550-570 \\
\text { FASE } 10.3 \\
\text { 570-590 } \\
\text { FASE } 10.2 \\
590-\text { - } 625 \\
\text { FASE } 10.1 \\
\text { Post } 625\end{array}$ & $\begin{array}{l}\text { H. } 61,63,91 \mathrm{~A} \\
\text { H. } 80 \mathrm{~B}, 89,93 \mathrm{~A}, \\
99 \mathrm{~A}-\mathrm{B}, 104 \\
\text { H. } 61 \mathrm{~B}, 63,90,91 \mathrm{C}, \\
93 \mathrm{~B}, \\
80 \mathrm{~B} / 99,99 \mathrm{~B}-\mathrm{C}, 104 \mathrm{C} . \\
\text { H. 99c, 104c. } \\
\text { Lucerna H. IIB } \\
\text { H. 103, 105, 107, 99C } \\
\text { H. 99C, 104C, 105 } \\
\text { H. 99C, 104C, 105, 109, } \\
\text { 93/108 } \\
\text { H. 99C, 91D, 105, } \\
\text { 93/108, 109. } \\
\text { H. 99/C, 105 }\end{array}$ & $\begin{array}{l}\text { K.XXXVIB, K. LIIIA, } \\
\text { K. LIVD } \\
\text { K. LIII, XLI, } \\
\text { K. LXUUA, LXIIE, } \\
\text { LIIIA, LXV, } \\
\text { spateia, XXVIG } \\
\text { K. LXV, LXI. } \\
\\
\text { K. LXIA, LXIIE, LIII, } \\
\text { LV, spateia. XXVIG } \\
\text { K. LXIIB, } \\
\text { spateia XXVIG } \\
\text { K. LIIIA, LXI-LXII, } \\
\text { spateia XXVIC, XXVIG } \\
\text { K. LXI, XXXII, LIII, } \\
\text { LXII }\end{array}$ & $\begin{array}{l}\text { Vila-roma 5.40, Ramón } \\
\text { RE 0204b } \\
\text { F. } 3.1,11,4.1,4.2 . \\
\text { Fulford, G.2, Atlante I, } \\
\text { CVII, 5-7. } \\
\text { Fulford, G.2. Vila-roma, } \\
6.116 . \\
\text { Vegas 40, F. 1:4, 3.1, 11, } \\
12,2.4 \text {. } \\
\text { Vegas } 21 \text { Ramón RE- } \\
\text { 0204B } \\
\text { Fulford } 4 \\
\text { Fulford G. } 3, \text { G9. } \\
\text { Atlante I, 108, } 4\end{array}$ & $\begin{array}{l}\text { F. } 1.2,1.3,1.4,5 \text {. } \\
\text { F. } 3,5,11,12 . \\
\text { F. } 1.1,7,13 . \\
\text { F. } 2.2,7 .\end{array}$ \\
\hline
\end{tabular}




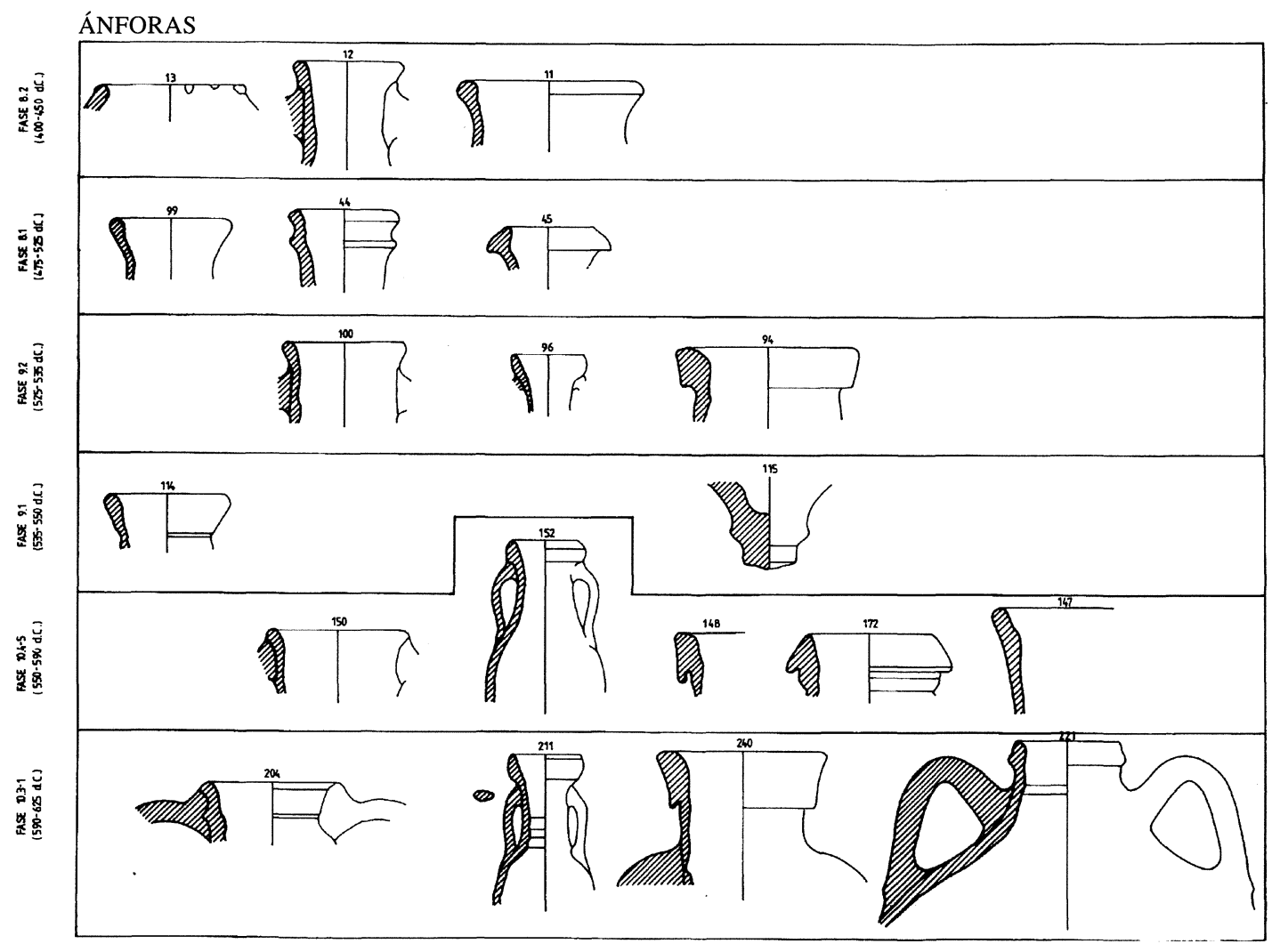

PRODUCCIÓN: TOSCA LOCAL

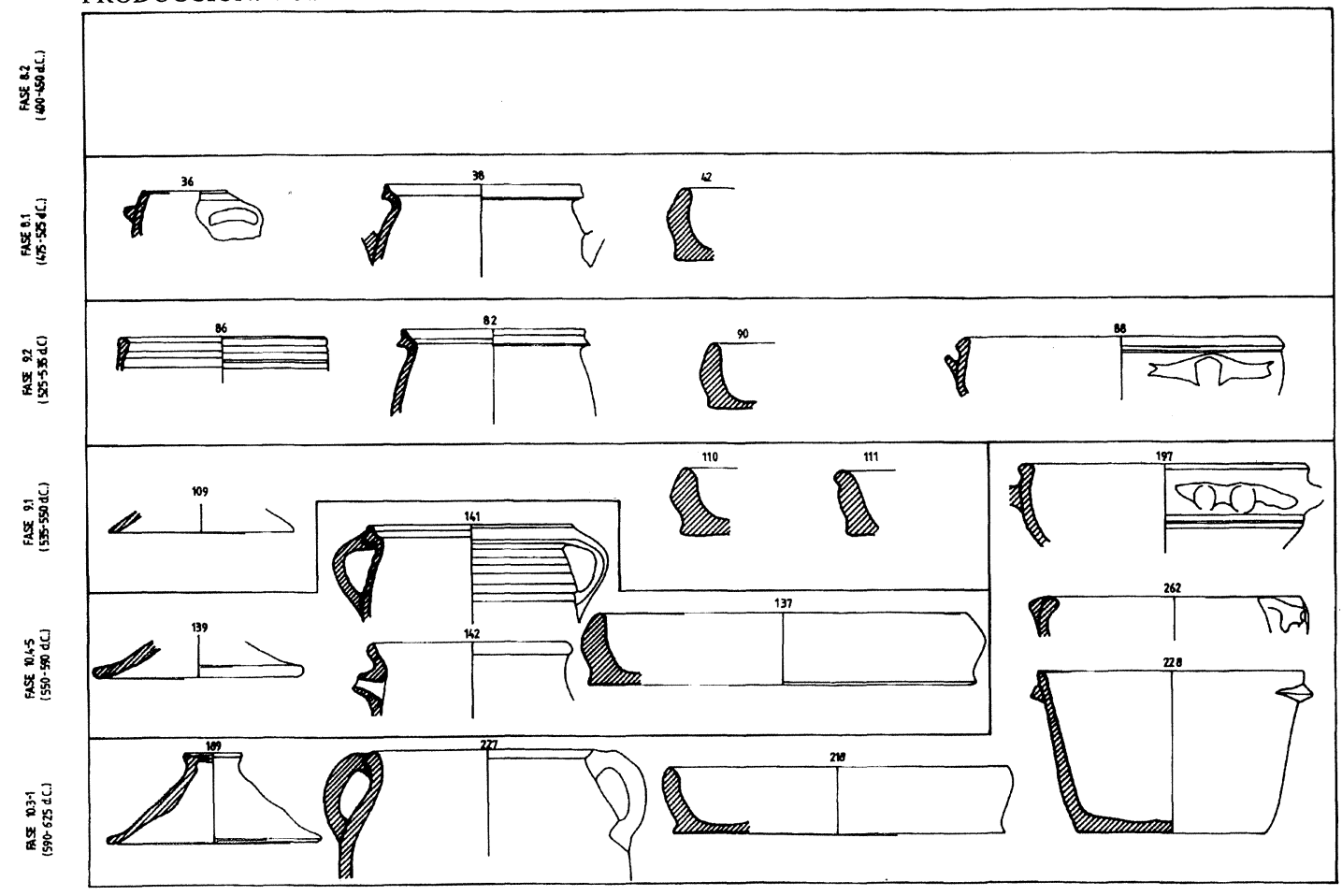

Figura 21 


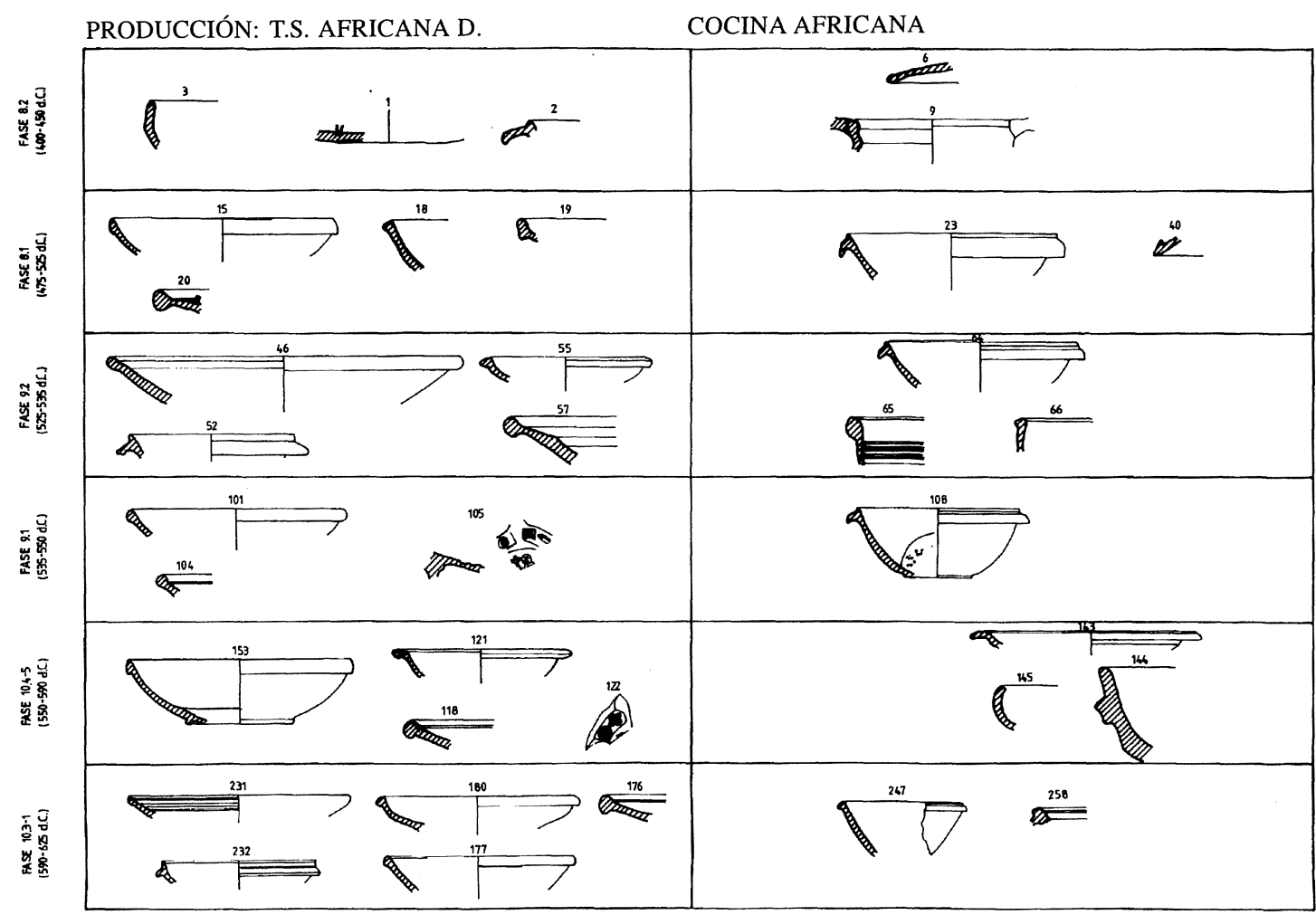

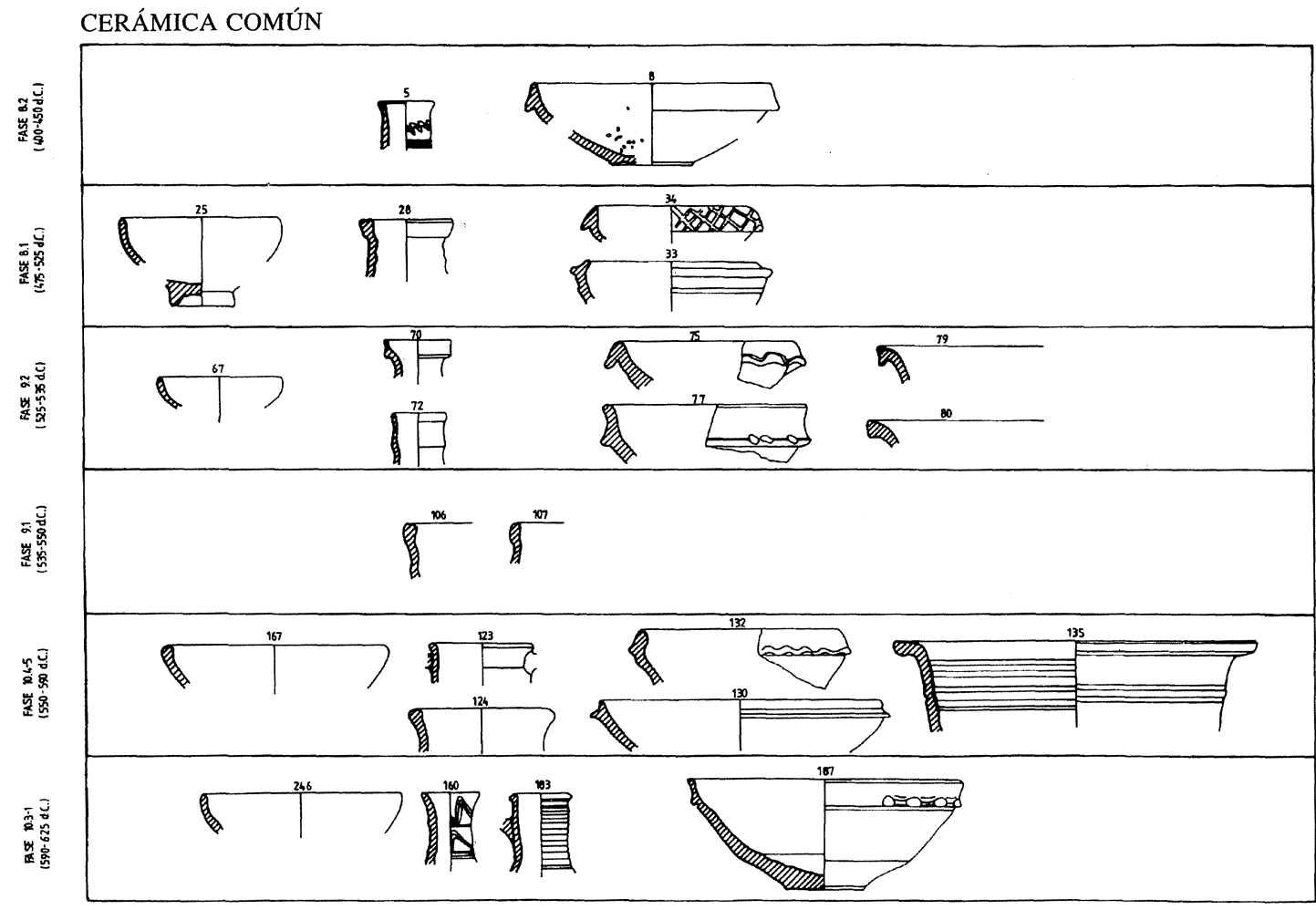




\section{BIBLIOGRAFÍA}

Aharoni, Y. (1964): «Excavation at Ramath-Rabel. Seasons 1961-1962», Serie Archeologica 6, Centro di Studi Semitici, Roma.

Amante, M. (1984): «La cerámica común romana de Begastri», Antig.Crist., I, 93-99.

AQuilué, X. (1987): Las cerámicas africanas de la ciudad romana de Baetulo (Hispania Tarraconensis), BAR, Is., 337.

- (1989a): «Terra sigillata africana», in: TED'A, Un abocador del secle $v$ d.C. en el fórum provincial de Tarraco, M.E. 2, Tarragona.

- (1989b): «Les ceramiques comunes de producció africana», in: Un abocador del secle $\mathrm{v}$ d.C. en el fórum provincial de Tarraco, M.E., 2, Tarragona.

- (1989c): «Algunas consideraciones sobre el comercio africano: tres facies características de la cerámica común africana de época alto-imperial», Empuries 47, (1985), 210-221.

- (1992): Las cerámicas de producción africana procedentes de la colonia Iulia Urbs Triumphalis Tarraco, Col. de Tesis doctorales microfichadas, . $^{\circ}$ 1275, Universidad de Barcelona.

- (1993): La seu del Col.legi d'Arquitectes. Una intervenció arqueològica en el centre històric de Tarragona. Tarragona.

Atlante I (1981): Atlante delle forme ceramiche I. Ceramica fine romana nel bacino Mediterraneo (Medio e Tardo-Impero). Roma.

BALDASSARE, I. (1967): «La ceramica delle necropoli longobarde di Nocera Umbra e Castel Trosino», Alto Medioevo, 1, 141-177.

Bass, G., y van Doorninck, F. (1982): Yassi Ada. A seventh century Byzantine shipwreck, vol. I, Texas University Press.

Beltrán, M. (1970): Ánforas romanas en España, Zaragoza.

Berrocal, M. C. (1987): «Nuevos hallazgos sobre el foro de Carthago Nova», Los Foros romanos de las provincias occidentales, Madrid, 137 142.

Blasco, J., Escrivà, V., y SoRIANo, R. (1994): «Assaig de síntesi del panorama ceràmic de la ciutat de Valencia a l'antiguitat tardana», III Reunió d'Arqueologia Cristiana Hispànica, Maó (1988), Barcelona, 357-373.

Boardman, J. y Hayes, J.W. (1973): «Excavations at Tocra 1963-1965. The Arcaic Deposits II and Later Deposits», Vol. II, B.B.S.A.A. Atenas.

BoIXADERA, M. et alii (1987): «L'habitat de hauteur de Sainte-Popice. L'ocupation de l'antiquité tardive», DocAMerid, 10, 91-113.
Bolufer, J. (1994): «Les ceràmiques tardanes importades (segles IV-VII de la n.e.) del jaciment de la Punta de l'Arenal (Xàbia, Marina Alta)», III Reunió d'Arqueologia cristiana hispànica, Maó (1988), Barcelona, 375-389.

Bonifay, M. (1983): «Éléments d'evolution des céramiques de l'Antiquité Tardive à Marseille d'aprés les fouilles de La Bourse (1980-1981)», RANarb, 16, 285-346.

- (1986): «Observations sur les amphores tardives à Marseille d'aprés les fouilles de la Bourse 1980-1984», RANarb, 19, 269-305.

Bourgeois, A. y MAYET, F. (1991): Belo VI. Les sigillées, Collection de la Casa de Velázquez, 34 (Archéologie XIV), Madrid.

CARANDINI, A. et alii (1981): Vid. Atlante delle forme ceramiche I. Ceramica fine romana nel bacino Mediterraneo (Medio e Tardo-Impero). Roma.

Carignani, A. et alii (1986): «Roma. Il contesto del tempio della Magna Mater sul Palatino», Società romana e impero tardoantico (A. Giardina, ed.), vol. III, 27-43, Roma.

Clariana, J. F. y Járrega, R. (1994): «Estudi de la fase baix imperial de la Vil.la romana de Torre Llauder (Mataró, El Maresme). Les ceràmiques», Laietana, 9, 253-289.

Clay, T. (1990): "Carthage et son commerce dans l'antiquité tardive». $V^{e}$ Coll. sur l'hist. et l'archéol. de l'Afrique du Nord, Avignon, 349359.

Delgado, M. (1975): «Les sigillées claires», Fouilles de Conimbriga, IV, 249-291.

Deneauve, J. (1972): «Céramique et lampes africaines sur la côte de Provence», Ant.Af., VI, 219227.

Dupré, X. y CARreté, J. M. (1993): La «antiga audiència». Un acceso al foro provincial de Tarraco, EAE, 165, 117-165.

Fiumi, F. y Prati, L. (1983): «Note sulle ceramiche comune», Ravenna e il porto di Classe, Bologna, 118-126..

Fulford, M. G. y PEACOCK, D. P. S. (1984): Excavations at Carthage: The British Mission, vol. I. The Avenue du President Habib Bourguiba Salammbo: The pottery and other ceramic objets from the site, Sheffield.

- (1994): Excavations at Carthage, The British Mission. The Circular Harbour, North Side, vol. II, 2.

Gutiérrez, S. (1988a): Cerámica común Paleoandalusí del sur de Alicante. Siglos VII-X. Alicante.

- (1988b): «El poblamiento tardorromano en Alicante a través de los testimonios materiales. Es- 
tado de la cuestión y perspectivas», Antig.Crist., V, 323-337.

- (1993): «De la civitas a la madina: destrucción y formación de la ciudad en el sureste de AlAndalus. El debate arqueológico», IV CAME, I Ponencias, octubre de 1993, 13-35.

HAYES, J. W. (1968): «Excavations in Sarachane in Istambul», Dumbarton Ocasional Papers, 22, 205 y ss.

- (1972): Late Roman Pottery, London.

—. (1976): «Pottery: stratified groups and tipology $\gg$, in: Michigan $\mathrm{I}, 47-125$.

- (1980): A supplement to Late Roman Pottery, London.

JÁRREGA, R. (1987): «Notas sobre la importación de cerámicas finas norteafricanas (sigillata clara D) en la costa oriental de Hispania durante el siglo vi e inicio del viII d.C.» II CAME, 337-344.

- (1991): Cerámicas finas tardorromanas y del Mediterráneo oriental en España. Estado de la cuestión. Anejos de AEspA, XI, Madrid.

KEAY, S. (1984): Late Roman Amphore in the western Mediterranean. A tipology and economic study: the Catalan evidence, BAR, I.S., 192.

- (1987): «La importación de vino y aceite en la Tarraconense oriental en la antigüedad», $E l$ vi a l'antiquitat. Economia, producció y comerç al Mediterrani Occidental, Col.loqui, Badalona, 1985, Monografies Badalonines, 9.

LÁIz M. a D., Pérez, L. M. y Ruiz, E. (1987): «Nuevos hallazgos bizantinos en Cartagena», AEspA, LX, 281-285.

LÁiz, M. ${ }^{a}$ D. y Berrocal, M. ${ }^{a}$ C. (1995): «Elementos para la datación cronológica de la necrópolis paleocristiana de San Antón. Cartagena», IV Reunió d'Arqueología Paleocristiana Hispànica (Lisboa, 1992), 163-173.

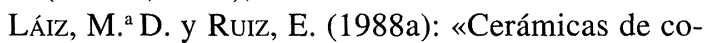
cina de los siglos V-VII en Cartagena (C/Orcel-D. Gil)», AntigCrist., V, 265-301.

- (1988b): «Área de tabernae tardorromanas en Cartagena», AntigCrist., V, 425-433.

Láiz, M. ${ }^{a}$ D. y Berrocal, M. ${ }^{a}$ C. (1991): «Un vertedero tardío en C/ Duque 33». AntigCrist., VIII, 321-340.

Lechuga, M. y Amante, M. (1991): «El yacimiento romano de "Los Villaricos" (Mula, Murcia). Aproximación al estudio de un establecimiento rural de época romana en la Región de Murcia», AntigCrist., VIII, 363-379.

Mackensen, M. (1985): «Prospection einer spätantiken Sigillatöpferei in El Mahrine (Nordtunisien)», CEDAC, 6, 29-39.

Martín, G. (1983): «Terra sigillata clara de Pollen- tia». Pollentia 3. Estudio de los materiales I. Sa Portela. Excavaciones 1957-1963, 169-240.

MARTín, G. et alii (1979): Excavaciones en la ciudadela de Roses (Campaña 1976-1977), Girona.

MARTíneZ ANDREU, M. (1985): «La muralla bizantina de Carthago Nova», AntigCrist., II, 129-151.

Martínez Rodríguez, A. y Matilla Seiquer, G. (1988): «Poblamiento tardío en Torralba, Lorca», Antig.Crist., V, 537-538.

Matilla, G. (1988): «El Castillo de los Garres: una fortaleza tardía en la Vega de Murcia», Antig. Crist., V, 352-402.

Matilla, G. y Pelegrín, I. (1985): «El Cerro de la Almagra y Villaricos. Sobre el poblamiento urbano y su entorno en los siglos de la antigüedad tardía», Antig.Crist., II, 281-302.

MÉndez ORTIZ, R. (1985): Estudio histórico-arqueológico del conjunto de la Plaza de los Tres Reyes, Murcia. Tesis de licenciatura inédita.

- (1988): «El tránsito a la dominación bizantina en Cartagena: Las producciones cerámicas de la Plaza de los Tres Reyes», AntigCrist, V, 31-164,

Méndez, R. y Ramallo, S. (1985): «Cerámicas tardías (ss. IV-VII) de Carthago Nova y su entorno», Antig.Crist., II, 231-280.

MichigAN I = Humphrey, J. H. (ed.): Excavations at Carthage, 1975, conducted by the University of Michigan, vol. I, Tunis, 1976.

Michigan IV = HumphreY, J. H. (ed.): Excavations at Carthage 1976, conducted by the University of Michigan, Ann Arbour, 1978.

Miquel, L. (1987): «El trazado viario de Carthago Nova (Nuevos hallazgos del decumano máximo)». AnMurcia, 3, 150.

Miquel, L. (1993): «C/ Caballero-C/ San Antonio el Pobre», IV Jornadas de Arqueología Regional, Murcia, 30, con planta del edificio.

NAVARRO, R. (1982): «Las cerámicas finas de la basílica de Fornells, Menorca», II Reunió d'arqueologia paleocristiana hispànica, Montserrat (1978), Barcelona, 431-454.

Neuru, L. (1980): «Late Roman Pottery: a fifth century deposit from Carthage», AntAfr., 16, 195211.

Nieto Prieto, J. (1993): El edificio «A» de la ciudadela de Roses (la terra sigillata africana), Girona.

Nolla, J. M. (1984): Excavaciones recientes en la ciudadela de Rosas. El edificio bajo-imperial, BAR, I.S. 193 (II), 430-459.

OlCESE, G. (1993): Le ceramiche comuni di Albentimilium, Università di Siena.

Orfila, M. y CAU, M. A. (1992): «Las cerámicas finas procedentes de la cisterna de Sa Mesquida, 
Calvià (Mallorca)», III Reunió d'Arqueologia Cristiana Hispànica, Maó (1988), Barcelona, 257-288.

OrfiLA, M. (1989): «Cerámicas de la primera mitad del siglo v d.C. procedentes de la cisterna de Sa Mesquida (Santa Ponça, Mallorca)», L'Africa Romana, VI (Sassari 1988), Sassari. 513-533.

Pacetti, F. y SFrecola, S. (1989): «Ceramiche africane di vi secolo provenienti da una domus tardoantica del Celio. Sintesi storica e indagine mineralogica», L'Africa Romana, VI, Sassari, 485-504.

Peacock, D. P. S. y Willians, D. F. (1986): Amphorae and the Roman economy. An introductory guide, London.

Pensabene, P. (1985): «Le anfore con iscrizioni cristiane», in: Whitehouse et alii, «The Schola Praeconum II», PBSR, LIII, 190-200.

Pérez Bonet, M. A. (1988): «La economía tardorromana del sureste peninsular: el ejemplo de Puerto de Mazarrón (Murcia)», Antig.Crist., V, 471501.

Ramallo Asensio, S. (1984a): «Algunas consideraciones sobre el Bajo Imperio en el litoral murciano: los hallazgos romanos en Aguilas», AUM, XLII, 3-4, 97-124.

- (1984b): «Terra sigillata en Begastri. Hacia una aproximación global del tema», Antig.Crist., I, 63-70.

- (1985): «Envases para salazón en el Bajo Imperio», VI CIAS, Cartagena, 1982, 435-442, Madrid.

- (1989-1990): «Termas romanas de Carthago Nova y alrededores», AnMurcia, 5-6, 161-165.

- (1991): «Informe preliminar de los trabajos realizados en la Basílica paleocristiana de Aljezares (Murcia)», Memorias de Arqueología, 2, (19851986), Murcia, 297-307.

Ramallo Asensio, S.; San Martín Moro, P.A. y RuIZ VALDERAS, E. (1993): «Teatro romano de Cartagena. Una aproximación preliminar», Cuadernos de Arquitectura Romana, 2, 51-92.

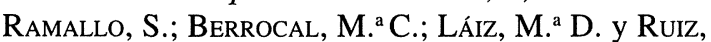
E. (1994): «Carthago Spartaria», Bulletin de la Association pour l'Antiquité tardive, 3, annuaire, 90-91.

RAMón, J. (1986): El Baix Imperi: l'epoca bizantina a les illes Pitiuses, Ibiza.

Remolá, J. A. y Abelló, A. (1989): «Les amphores», in: Un abocador del secle $v$ d.C. en el fórum provincial de Tarraco, M.E., 2, 249-320.

Reynolds, P. (1984): African Red slip and late Roman imports in Valencia, BAR, I.S., 193 (II), 474-539.
- (1985): «Cerámica tardorromana modelada a mano de carácter local, regional y de importación en la provincia de Alicante», Lucentum, II, 147-172.

- (1987): El yacimiento tardorromano de Lucentum (Benalúa, Alicante): las cerámicas finas, Alicante.

- (1993): Settlement and Pottery in the Vinalopó Valley (Alicante, Spain), AD., 400-700, BAR, IS., 588.

Riley, J. A. (1982): «New light on relations between the Eastern Mediterranean and Carthage in the Vandal and Byzantine periods: the evidence from the University of Michigan excavations», Actes du colloque sur la céramique antique (Carthago, 1980), CEDAC, I, Túnez, 111122.

- (1983): Excavations at Sidi Khrebish Bengha$z i$ (Berenice), Suplements to Lybia Antiqua, v, vol. II.

Robinson, H. (1959): The Athenian Agora, v: Pottery of the Roman period, Princeton.

RoldÁn, B. et alii (1991): «Contribución a la historia económica de Carthago Nova durante los siglos v y vi d.C.: el vertedero urbano de la calle Palas», AntigCrist., VIII, 305-319.

Ruiz Valderas, E. (1991): «Núcleo urbano y necrópolis de la calle Era, en el Puerto de Mazarrón», Verdolay, 3, 45-58.

- (e.p.): «Los niveles de abandono del siglo II en Carrtagena: los contextos de la calle Jara $\mathrm{n}^{\circ} 12$ », XIV CNA, Elche, 1995.

Ruiz, E.; Ramallo, S.; LÁIz, M. ${ }^{a}$ D. y Berrocal, M. ${ }^{a}$ C. (1993): "Transformaciones urbanísticas de Carthago Nova (siglos III-XIII)», IV CAME. vol. II, 59-65.

SAN MARTín, P. (1973): «Prospecciones arqueológicas en solares urbanos de Cartagena», Mastia, 4$5,47-50$.

SAn Martín, P. y Palol, P. (1972): «Necrópolis paleocristiana de Cartagena», VIII Congreso Internacional de Arqueología Cristiana, Barcelona (1968), Roma, 447-458.

Stoppioni, M. L. (1983): «Le anfore». Ravenna e il porto di Classe, Bologna, 130-146.

TALler Escola D'ARQUeOlogia (1989): Un abocador del segle $v$ d.C. en el fòrum provincial de Tàrraco, Memòries d'excavació, 2. Tarragona.

- (1994): «Vila-roma: un abocador del segle v dC. en el forum provincial de Tarraco (Hispania Tarraconensis)», III Reunió d'Arqueologia cristiana hispànica, Mahón, 1988, Barcelona, 339-356.

Tortorella, S. (1981): «Ceramica di produzione africana e rinvenimenti archeologici sottomarini 
della media e tarda etá imperiale: analisi dei dati e dei contributi reciprochi», MEFRA, 93, 355380 .

- (1986): «La ceramica fine da mensa africana del Iv al vil secolo d. C.», in Giardina, A. (ed.): «Le merci. Gli insediamenti», en Società romana $e$ Impero tardo-antico 3, Roma, 211-225.

- (1987): «La ceramica africana: un riesame della problematica», Céramiques hellénistiques et romaines, II, 279-327.

VEGAS, M. (1973): La cerámica común romana en el Mediterráneo occidental, Barcelona.

VidAL, M. y Miquel, L. (1988): «El abandono de una casa romana en Cartagena (solar C/. Cuatro
Santos, $\mathrm{n}^{\circ}$ 40)», Antig.Crist., V, 435-448.

Villedieu, F. (1984): «Turris Libisionis. Fouille d'un site romain tardif à Porto Torres, Sardaigne», BAR, I.S:, 224.

Whitehouse, D. et alii (1982): «The Schola Praeconum I: The Coins, Pottery, Lamps and Fauna», PBSR, L, 53-10.

- (1985): «The Schola Praeconum II», PBSR, LIII, 163-210.

Willians, D. F. (1982): «The petrology of certain Byzantine amphorae: some suggestions as to origins. Actes du Colloque sur la Céramique Antique (1980)», CEDAC, Dossier 1, Carthago, 99110 , Tunis. 